James Madison University JMU Scholarly Commons

Senior Honors Projects, 2010-current

Honors College

Summer 2017

\title{
Characterizing subsurface void spaces and water distribution and flow patterns in Cave Hill Karst using resistivity
}

Jacob A. Gochenour

James Madison University

Follow this and additional works at: https://commons.lib.jmu.edu/honors201019

Part of the Geology Commons, Geomorphology Commons, Geophysics and Seismology Commons, and the Hydrology Commons

\section{Recommended Citation}

Gochenour, Jacob A., "Characterizing subsurface void spaces and water distribution and flow patterns in Cave Hill Karst using resistivity" (2017). Senior Honors Projects, 2010-current. 266.

https://commons.lib.jmu.edu/honors201019/266

This Thesis is brought to you for free and open access by the Honors College at JMU Scholarly Commons. It has been accepted for inclusion in Senior Honors Projects, 2010-current by an authorized administrator of JMU Scholarly Commons. For more information, please contact dc_admin@jmu.edu. 


\title{
Characterizing Subsurface Void Spaces and Water Distribution \\ and Flow Patterns in Cave Hill Karst Using Resistivity
}

\author{
An Honors College Project Presented to \\ the Faculty of the Undergraduate \\ College of Science \& Mathematics \\ James Madison University
}

by Jacob Alexander Gochenour

April 2017

Accepted by the faculty of the Department of Geology \& Environmental Science, James Madison University, in partial fulfillment of the requirements for the Honors College.

FACULTY COMMITTEE:

Project Advisor: R Shane McGary, Ph.D. Assistant Professor, Department of Geology \& Environmental Science

Reader: Yonathan Admassu, Ph.D.

Assistant Professor, Department of Geology \&

Environmental Science

Reader: John Haynes, Ph.D.

Associate Professor, Department of Geology \&

Environmental Science

Reader: Steve Baedke, Ph.D.

Professor, Department of Geology \&

Environmental Science
HONORS COLLEGE APPROVAL:

Bradley R. Newcomer, Ph.D.,

Dean, Honors College 


\section{PUBLIC PRESENTATION}

This work is accepted for presentation, in part or in full, at the James Madison University Honors Symposium, Madison Union Ballroom on 21 April 2017 
(C) 2017 Jacob Alexander Gochenour 
In dedication to my father, Val Lindy Gochenour, who raised me to respect and cherish the natural world, and to my grandfather, Larry Vinton Gochenour, who inspired my love of travel, maps, and geography. 


\section{Table of Contents}

$\begin{array}{ll}\text { List of Figures } & 06\end{array}$

$\begin{array}{ll}\text { Acknowledgements } & 08\end{array}$

$\begin{array}{ll}\text { Abstract } & 09\end{array}$

1. Introduction $\quad 11$

2. Geologic Setting 16

3. Electrical Resistivity Theory and Background 20

4. Data \& Methods 23

4.1. Electrical Resistivity Equipment 23

4.2. Electrical Resistivity Deployment Locations 25

4.3. Electrical Resistivity Data Processing 29

4.4. Structural Geology \& Geospatial Investigation 30

5. Results 34

5.1. Location 1, Electrical Resistivity 34

5.2. Location 2, Electrical Resistivity 36

5.3. Structural Geology \& Geospatial Results 37

6. Interpretations \& Discussion 44

6.1. Location 1, Karstic Swale 44

6.2. Location 2, Caverns $\quad 55$

$\begin{array}{ll}\text { 6.3. Conclusions } & 60\end{array}$

$\begin{array}{ll}\text { Appendices } & 68\end{array}$

$\begin{array}{ll}\text { Bibliography } & 88\end{array}$ 


\section{List of Figures}

Figures

1a Commonwealth of Virginia map 12

1b Aerial image of the Cave Hill study area 12

$\begin{array}{lll}2 \mathrm{~b} & \text { Aerial image across four carbonate bedrock formations } & 13\end{array}$

2a LiDAR DEM hillshade + topographic position index map 13

3 Geologic map of the Shenandoah Valley, Virginia. 18

4a Electrical resistivity Schlumberger array schematics 21

4b Electrical resistivity dipole-dipole array schematics 21

$5 \quad$ Electrical resistivity 56-electrode command files 22

$6 \quad$ Electrical Resistivity equipment schematics 24

$\begin{array}{lll}7 & \text { Map of study locations } & 26\end{array}$

$8 \quad$ Map of location 1 electrical resistivity lines $\quad 27$

$9 \quad$ Map of location 2 electrical resistivity lines 27

10a Stereonet of southeast anti-form fold axis 31

10b Stereonet of northwest anti-form fold axis 31

11 Strike and dip measurements and cross-section profile locations 31

12 Simulated surface flow pathways 33

13 Electrical resistivity section SW04M result 35

$14 \quad$ Electrical resistivity section SW07M result 35

15 Electrical resistivity section GCDD01M-06M result 39

16 Electrical resistivity section GCDD09 result 39 
17a Cross-section B-B', location $1 \quad 41$

17b Parasitic folding near location 1

17c $\quad$ Cross-section A-A', location $2 \quad 41$

18 Simulated surface flow pathways, location 1

$19 \quad$ Simulated surface flow pathways, location $2 \quad 43$

$20 \quad$ Correlated electrical resistivity sections, location 1

21 Correlated electrical resistivity sections, location 1

22 Correlated electrical resistivity section, location $1 \quad 50$

$23 \quad$ Interpreted electrical resistivity sections, location 1

24 Interpretive mosaic of electrical resistivity sections, location $1 \quad 54$

$25 \quad$ Interpreted electrical resistivity section and map, location $2 \quad 59$

$26 \quad$ Interpreted electrical resistivity section and map, location $2 \quad 60$

$27 \quad$ Interpretive map of possible fold axes trends 64

28 Map of suggested future electrical resistivity deployments 66

29 Map of EM deployments and suggested future EM deployments $\quad 67$

Tables

1 Stratigraphic column of Cambrian-Ordovician DCM sediments 


\section{Acknowledgements}

I would like to show my thanks and appreciation to my research advisor, Dr. $\mathrm{R}$ Shane McGary. Your support and encouragement has been vital to my success as a student. I would also like to thank my senior project committee readers, Dr. Yonathan Admassu, Dr. John Haynes, and Dr. Steve Baedke, for taking the time out of your busy schedules to assist me on the project. I am grateful to my research assistants Gregory Gosselin, Ben Suranovic, and Reagan Cronin. Your help and knowledge has been valuable to achieving the objectives of the project. I would like to extend my gratitude to the project area property owners, Daniel Chapman, Lyall Steger, and the Town of Grottoes Virginia, for being most accommodating to our research team. Without your support, the project would have not been possible. I hope this report can provide you with additional information about the geology of your beautiful land. I would additionally like to thank the Grottoes Tourism and Park Director, Nathan Garrison, and Dr. Daniel Doctor of the United States Geological Survey. Your coordination with me enabled this project to flow smoothly from start to finish. Lastly, but certainly not least, I would like to express my gratitude to the donors of the William Frangos Award for Geophysics and Quantitative Environmental Geology and the Judith R. Hoffman Science \& Mathematics Scholarship for providing me with endowments. Your assistance has helped to allow me to focus more on studies and less on financial support. 


\begin{abstract}
Describing the distribution of groundwater is essential in understanding the evolution of geomorphologic features in karst topography. Electrical resistivity allows us to find a model of subsurface distribution of resistivity that enables the visual recognition of groundwater and void spaces. The purpose of this research is to implement electrical resistivity to describe the spatial relationship of groundwater and karstic features at Grand Caverns National Natural Landmark, Grottoes, Virginia. Two locations of interest, a karstic swale and sinkhole area, were identified for the deployment of electrical resistivity. Both, dipole-dipole and Schlumberger arrays were collected for each deployment. A total of ten deployments, consisting of 14, 28, and 56 -electrodes spaced $6.25 \mathrm{~m}$ apart, were conducted in and/or around the features at both locations. Collected arrays were merged and inverted using AGI EarthImager 2D-Inversion Software. Geologic cross-sections were created for each location with collected strike and dip data and field observations made throughout the park. These along with geospatial digital elevation model data were used to correlate inverted resistivity sections to surface features. The results indicate that bedding geometry and rock type are controlling the water flow patterns and type of karstic features on Cave Hill. Groundwater escapes the southwestern portion of the hill by flowing along shallowly dipped bedding planes with the trend of plunge. The formation of the swale is likely due to collapse of long and narrow conduits created from this flow pattern. The results also show that two steeply-dipping confining beds hinder the expulsion of surface
\end{abstract}


and groundwater from the northwestern portion of Cave Hill. This water is collected in perched aquifers situated above the Caverns and bellow sinkholes that have formed along the confining beds. These aquifers likely feed water to the Caverns both from slow percolation and directly through conduits. 


\section{Introduction}

Grand Caverns Natural National Landmark lies in the southeastern Shenandoah Valley and is home to the oldest show cave in the United States (Fig. 1a). The park and adjacent private lands include a complex of five known caves: Grand Caverns, Madison Cave, Steger's Fissure, Jefferson Cave, and Fountain Cave, all encompassed within Cave Hill (Fig. 1b). Thomas Jefferson described and published a sketched map of Madison Cave in the 1782-1801 editions of his Notes on the state of Virginia (Halliday, 1968). George Washington's name is etched on a wall within Madison Cave. During the Civil War, both Union and Confederate soldiers visited Grand Caverns, and many signed their names on the cave walls. Grand Caverns continues to lure spectators, and the Town of Grottoes offers yearround tours of the intricate features found within the cave's rooms and chambers.

While the individual caves have received a lot of attention, the valley's karst topography has not been extensively studied (Doctor et al., 2014). Clusters of sinkholes can be readily seen in airborne-derived LiDAR (light detecting and ranging) digital elevation models (DEMs) (Fig. 2). Unknown karst voids can pose a risk to buildings, structures, and individuals; therefore, the Virginia Department of Emergency Management has listed sinkholes among several geologic hazards within the Commonwealth (Virginia Department of Emergency Management and Virginia Tech Center for Geospatial Information Technology, 2013). 


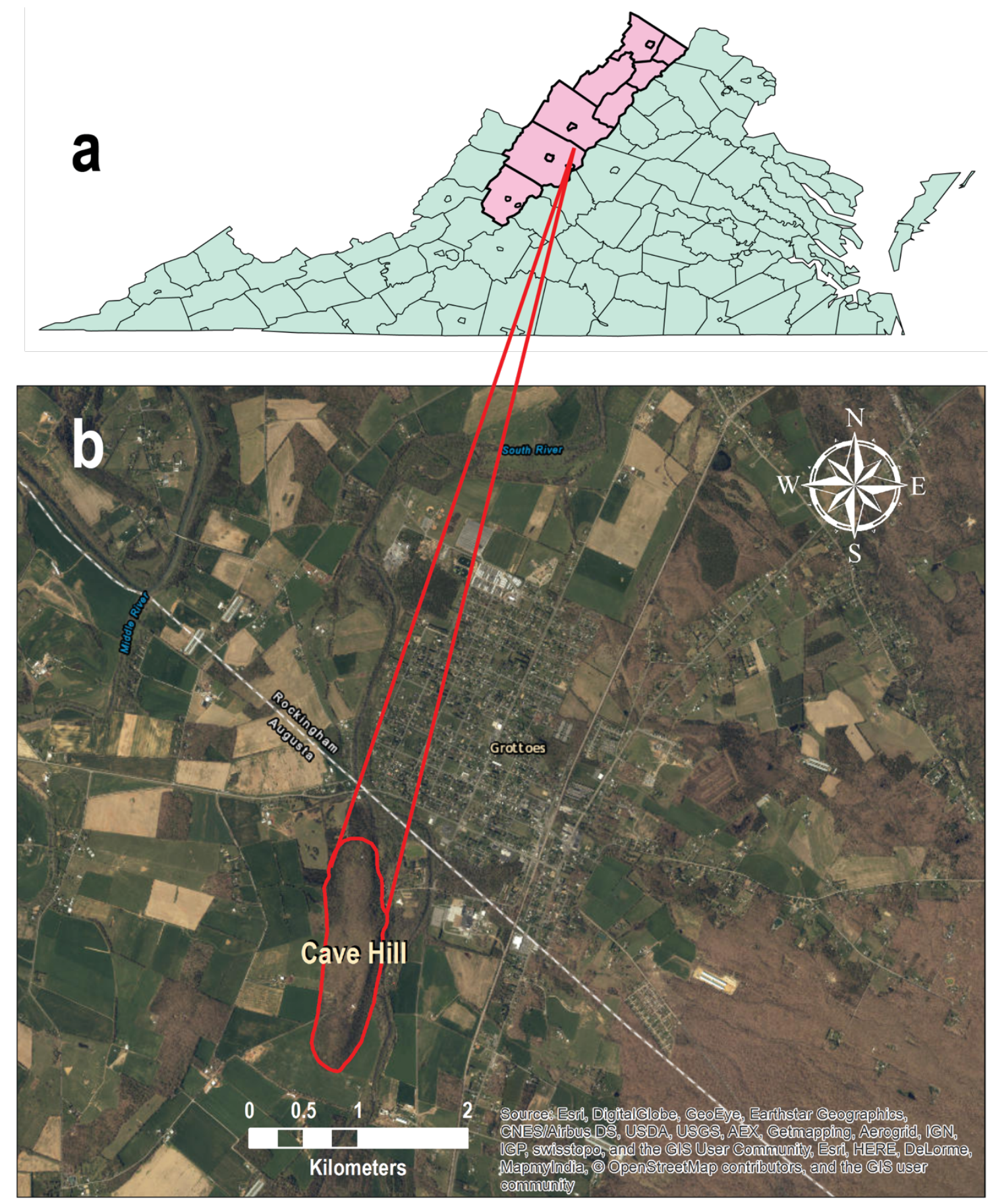

Figure 1 a. Commonwealth of Virginia map highlighting counties within the Shenandoah Valley in pink. The apex of two red lines mark the location of Grand Caverns Natural Landmark. b. Aerial imagery showing the vicinity of Grand Caverns Natural National Landmark, with Cave Hill outlined in red. Commonwealth of Virginia and county boundaries (figure 1a) adapted from Virginia Counties and Cities (Tiger 2013) shapefiles (Virginia Geographic Information Network and Virginia Information Technology Agency, 2013, Virginia Counties and Cities (TIGER 2013): Virginia GIS Clearinghouse Statewide Data Downloads: http://vgin.maps.arcgis.com/home/index.html (accessed September, 2016); and aerial base map (figure 1b) adapted from GIS data (Esri, Inc., 2016, [data/image]). 


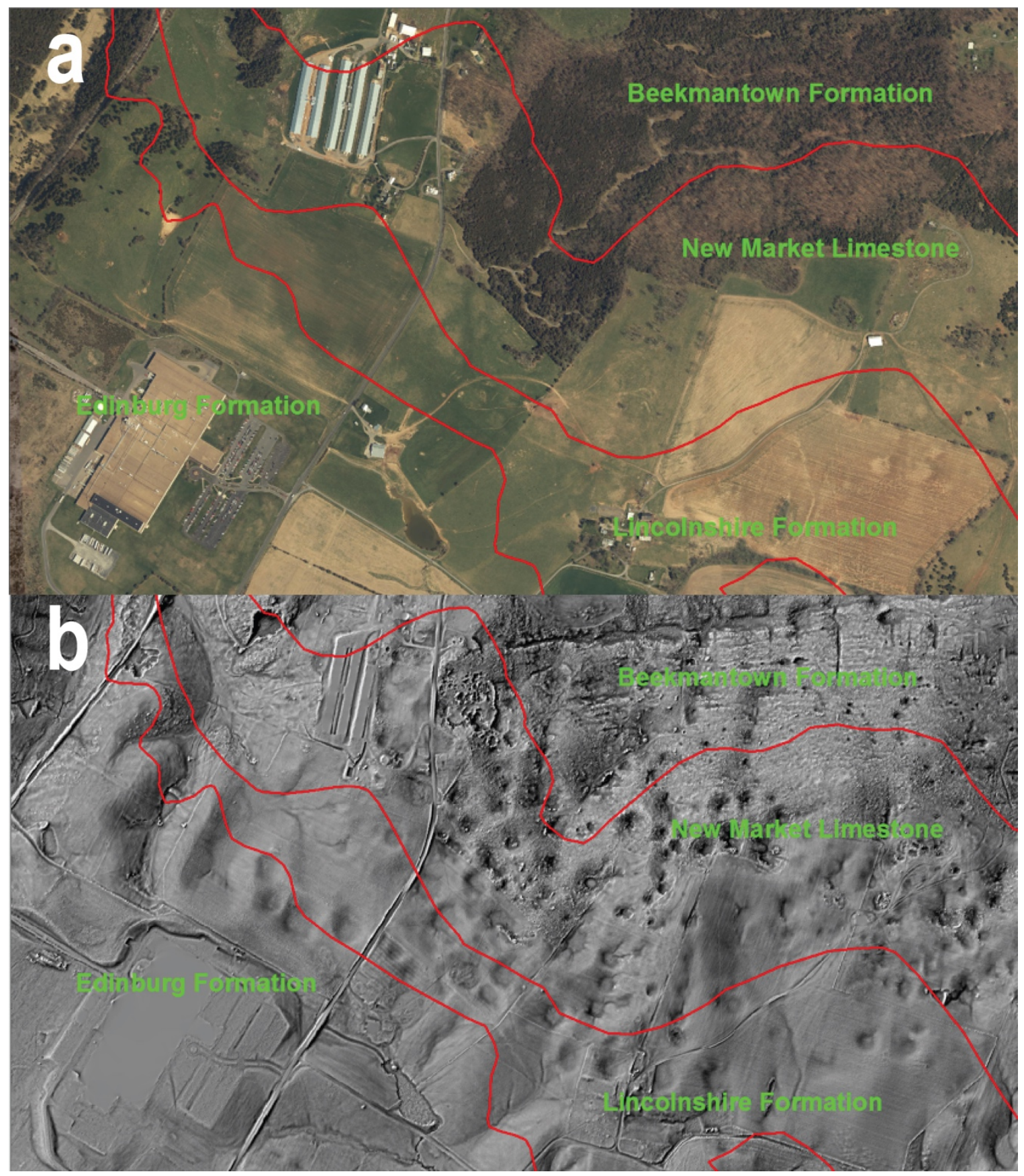

Figure 2 a. Aerial image across four carbonate formations showing structures and buildings $\mathbf{b}$. LiDAR derived hillshade + topographic position index map showing the existence of sinkhole clusters near structures and buildings, and the presence of sinkholes in four sequential geological formations. Geologic map overlay (figure 2a and 2b) adapted from the Geological Map of Virginia (Virginia Division of Mineral Resources, 1993, Geologic Map of Virginia: Virginia Division of Geology and Mineral Resources Publication 174 [CD-ROM; version 2, 2005] adapted from the Virginia the Virginia Division of Geology and Mineral Resources, 1993, Geologic Map of Virginia: Virginia Division of Mineral Resources, scale 1:500,000); Aerial imagery (figure 2a) adapted from a GIS base map package (Esri, Inc., 2016 [image/data]); and Hillshade + topographic position index base map (figure $2 \mathrm{~b}$ ) provided by Daniel Doctor of the U.S. Geological Survey (adapted from USGS, 2016, unpublished LiDAR [image/data]). 
Several recent local examples of structural damage due to formation of sinkholes exist. In September 2015, a sinkhole off the shoulder of Interstate-81 in Greenville, Virginia was repaired by the Virginia Department of Transportation to prevent further damage (Zinn, 2015). On February 29, 2016, in a parking lot in Harrisonburg, Virginia, a water truck triggered the collapse of a void space and formed a sinkhole (Edney, 2016). These examples suggest that an understanding of locating void spaces is important to the planning, development, and engineering of any new structures that are to be constructed in a karst environment. If unknown voids can be located before any construction, then potential damage and/or disasters may be prevented.

The location of void spaces and water pathways in the subsurface gives insight into the structure of a specific karst environment. Electrical resistivity (ER) and electromagnetic methods (EM) are particularly useful in locating these features due to contrasts in resistance between water, void spaces, and low permeable rock; thus, water is more conductive and void spaces are more resistive than the surrounding low-permeable bedrock. An ER investigation was conducted on Cave Hill to locate expected or suspected void spaces. Once identified, void spaces will be compared with surface and subsurface features to establish any correlations between them. These relationships must be compared to understand and interpret the karst system instead of independently assessing features such as bedrock, sediments, voids, and sinkholes. 
Since 2013, the USGS has been monitoring soil moisture content at different depths within the first meter below the surface of a sinkhole that is located approximately 46 meters above the Grand Caverns cave complex (pers. comm., Dan Doctor, U.S. Geological Survey). The USGS has also been measuring stable isotope values of cave drips entering the cave under the sinkhole. Differences in seasonal precipitation isotope ratios, specifically for oxygen, have been measured at the surface, but seem to be absent in the cave drips below. This suggests that the incoming water is homogenizing with water trapped in the subsurface between the sinkhole and the cave complex, which motivates the need for geophysics to locate subsurface water and void spaces. One of the objectives of this study is to locate subsurface water features such as perched aquifers using ER and EM near the sinkhole.

Several studies have applied multiple geophysical methods in efforts to detect both subsurface water and karstic voids (Doolittle and Collins 1998; Gibson, Lyle, and George 2004; Park et al. 2009; Chalikakis et al. 2011; Ismail and Anderson 2012; Margiotta et al. 2012; Nouioua et al., 2012). However, these studies serve more to compare the effectiveness of disparate methods, rather than integrating them in an effort to better constrain the geology of the subsurface. Nobes (1996) noted that integrating geophysical methods is a necessity for the advancement of subsurface imaging. We pursued a method of combining resistivity and electromagnetic data to improve the process of characterizing the subsurface distribution of water and void space. 


\section{Geologic Setting}

The Shenandoah Valley is part of the Valley and Ridge province of Virginia, and is nestled between the Blue Ridge fault to the east and the Little North Mountain fault to the west. These faults are part of a western verging foreland fold and thrust belt formed during the Alleghenian Orogeny when Gondwana collided with Laurentia (Faill, 1998; Rader and Gathright, 2001; Heller et al., 2007;

Whitmeyer et al., 2012). The valley is underlain by both siliciclastic and carbonate bedrock primarily deposited in marine environments during the Paleozoic (Fig. 3) (Rader and Gathright 2001).

Within the valley bedrock are Cambrian and Ordovician carbonate units deposited as divergent continental margin (DCM) sediments between the rifting of the Rodinia supercontinent and Taconic Orogeny (Table 1) (Rader and Gathright, 2001). These DCM units consist of the Shady, Rome, Elbrook, Conococheague, Stonehenge, Beekmantown, New Market, and Lower Lincolnshire formations (Rader and Gathright, 2001). Doctor et al. (2014) indicates that all the carbonate formations within the valley contain karst features that can readily be confirmed by aerial photographs and airborne LiDAR-derived DEM images such as in figure 2a and $b$, respectively.

Cave Hill is situated within the Cambrian age Conococheague Formation (Fig. 3), which commonly consists of laminated light- to dark-grey dolomitic limestone, thinly-bedded flat pebble conglomerate layers, course-grained calcareous arenite, algal-laminated dolostone and limestone that frequently contains 
mudcracks, ribbon rock, and chert after stromatolites (Gathright et al., 1978).

Interpreting these sedimentary structures suggests deposition of the

Conococheague was primarily influenced by cyclic eustatic sea-level changes within an environment that was dry and arid at times (Weber et al. 1995; Read and Repetski, 2012).

The primary geologic structure of Cave Hill is an anticline-syncline fold pair that has been overturned (Doctor et al., 2014). The South River flows alongside the eastern flank of Cave Hill. Much of the cavern passages within Cave Hill is located above river level; however, parts of Madison Cave and Steger's Fissure extend downward as deep as 30 meters below river level (Kastning, 1995; Doctor et al., 2014). Doctor et al. (2014) suggest that both Grand Caverns and Madison Cave were phreatically formed due to the presence of subaqueous calcite coatings as well as local clay and silt sized sediments with an absence of foreign sand, gravel, and cobble sediments.

It can be assumed that cave formation has been occurring in Cave Hill since at least 0.7 to 1.1 Mya due to evidence of two paleomagnetic reversals within the sediments of a room in Grand Caverns (Kastning, 1995; Doctor et al., 2014). However, the evolutionary biology of the phreatobytic crustacean Antrolana lira, commonly known as the Madison Cave isopod, found in Madison Cave and unique to the Shenandoah Valley, suggest that the karst, not necessarily cave formations, of Cave Hill formed no earlier than 4.4 to 7 Mya (Hutchins et al., 2010; Doctor et al., 2014). 


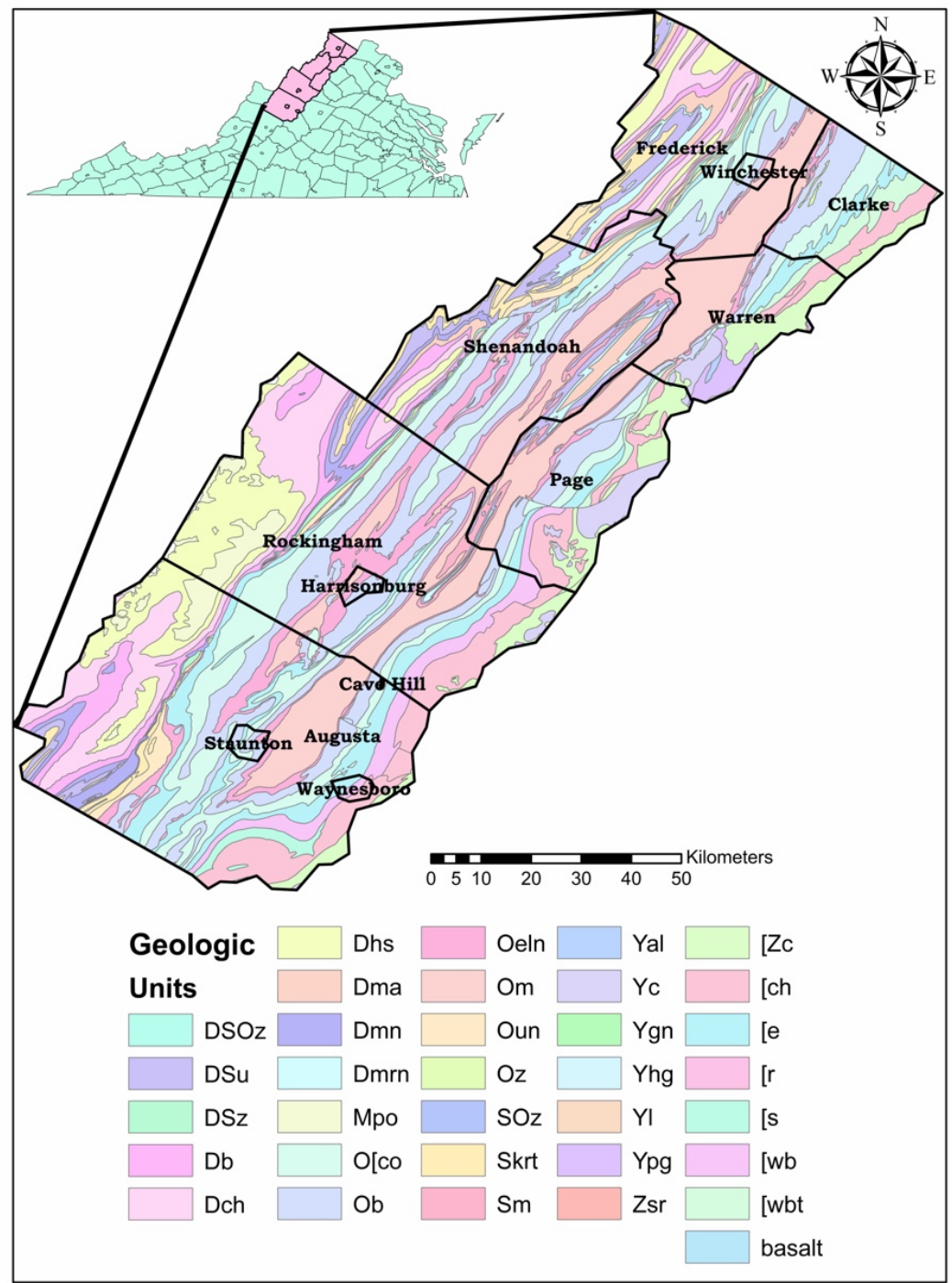

Figure 3. Geologic map of the Shenandoah Valley, Virginia. This region is underlain primarily by siliciclastic and carbonate bedrock that was deposited in marine and non-marine environments during the Paleozoic (Rader and Gathright, 2001). The open bracket ( [ ) denotes the Cambrian symbol ( $C$ ), and geologic formation symbols are described in Appendix A. Bedrock overlay adapted from the Geologic Map of Virginia (Virginia Division of Mineral Resources, 1993, Geologic Map of Virginia: Virginia Division of Geology and Mineral Resources Publication 174 [CD-ROM; version 2, 2005] adapted from the Virginia Division of Geology and Mineral Resources, 1993, Geologic Map of Virginia: Virginia Division of Mineral Resources, scale 1:500,000), Commonwealth of Virginia and county boundaries adapted from Virginia Counties and Cities (Tiger 2013) shapefiles (Virginia Geographic Information Network and Virginia Information Technology Agency, 2013, Virginia Counties and Cities (TIGER 2013): Virginia GIS Clearinghouse: Statewide Data Downloads: http://vgin.maps.arcgis.com/home/index.html (accessed September, 2016). 


\begin{tabular}{|c|c|c|c|}
\hline & LINCOLNSHIRE & $25-170$ & $\begin{array}{l}\text { Micrites, bio- and pelmicrites; } \\
\text { chert; abundant fossils; darkens } \\
\text { up section }\end{array}$ \\
\hline & NEW MARKET & $40-250$ & Pure micrites; tidal features \\
\hline & \multicolumn{3}{|c|}{ KNOX UNCONFORMITY } \\
\hline & BEEKMANTOWN & 2500 & $\begin{array}{l}\text { Thick bedded dolostone; black } \\
\text { chert; tidal features }\end{array}$ \\
\hline & STONEHENGE & 500 & $\begin{array}{l}\text { Blue thick bedded micrite; tidal } \\
\text { features }\end{array}$ \\
\hline & CONOCOCHEAGUE & 2500 & $\begin{array}{l}\text { Limestone; dolostone; quartz } \\
\text { arenite }\end{array}$ \\
\hline & ELBROOK & 2000 & $\begin{array}{l}\text { Blue-grey limestone/ dolostone } \\
\text { tidal features; }\end{array}$ \\
\hline & ROME & 2000 & $\begin{array}{l}\text { Red/green shale; dolostone; } \\
\text { micrite; very variable }\end{array}$ \\
\hline & SHADY & 1600 & $\begin{array}{l}\text { Dolostone (granular); Limestone } \\
\text { at top and bottom }\end{array}$ \\
\hline AGE & FORMATION & $\begin{array}{l}\text { THICK- } \\
\text { NESS (ft) }\end{array}$ & DESCRIPTION \\
\hline
\end{tabular}

Table 1. Stratigraphic column of carbonate formations deposited as divergent continental margin (DCM) sediments between the rifting of the Rodinia supercontinent and Taconic Orogeny. Grand Caverns Natural National Landmark lies within the Conococheague Formation highlighted in yellow, after Rader and Gathright (2001). 


\section{Electrical Resistivity Theory and Background}

Subsurface resistivity is typically measured by inducing an alternating current into the ground using a pair of electrodes. Voltage is measured across a second independent pair of electrodes. The relationship between the induced currents and the measured voltages allows us to calculate the impedance, which is a complex value for which the real part is the bulk resistance and the imaginary part tells us something about how charge is stored in the subsurface.

Since four electrodes are required to obtain a single impedance measurement and several different measurements are required to interpret the resistivity structure of the subsurface, resistivity cables are designed to electrically connect significant numbers of electrodes (14 to 56 for the present survey). The cables are designed in such a way that any two electrodes can inject current while any other two electrodes measure voltage; therefore, a large number of combinations of current and voltage electrodes can be programed to be recorded for any single deployment.

There are a small number of configurations of current/voltage electrodes that are considered standard. The two configurations that we used for this study were the Schlumberger and dipole-dipole arrays (Fig. 4). The Schlumberger array includes all possible configurations of adjacent voltage electrodes (spaced $6.25 \mathrm{~m}$ apart) with current electrodes spaced symmetrically to each side at varying distances (multiples of $6.25 \mathrm{~m}$ ) (Fig. 4a). The dipole-dipole array consists of every possible configuration of voltage electrodes spaced 6.25 meters apart and current electrodes, also spaced 
6.25 meters apart to one side of the voltage electrodes such that the distance between the nearest current electrode and voltage electrode is a multiple of 6.25 meters (Fig. 4b). For a 56-electrode cable, this allows for 454 and 762 measurements to be collected for the Schlumberger and dipole-dipole arrays, respectively (Fig. 5). Increasing the distance between the current electrodes and the voltage electrodes progressively increases the depth penetration of the sampled impedances. This also means that a longer electrode line is able to resolve deeper features than a shorter line.

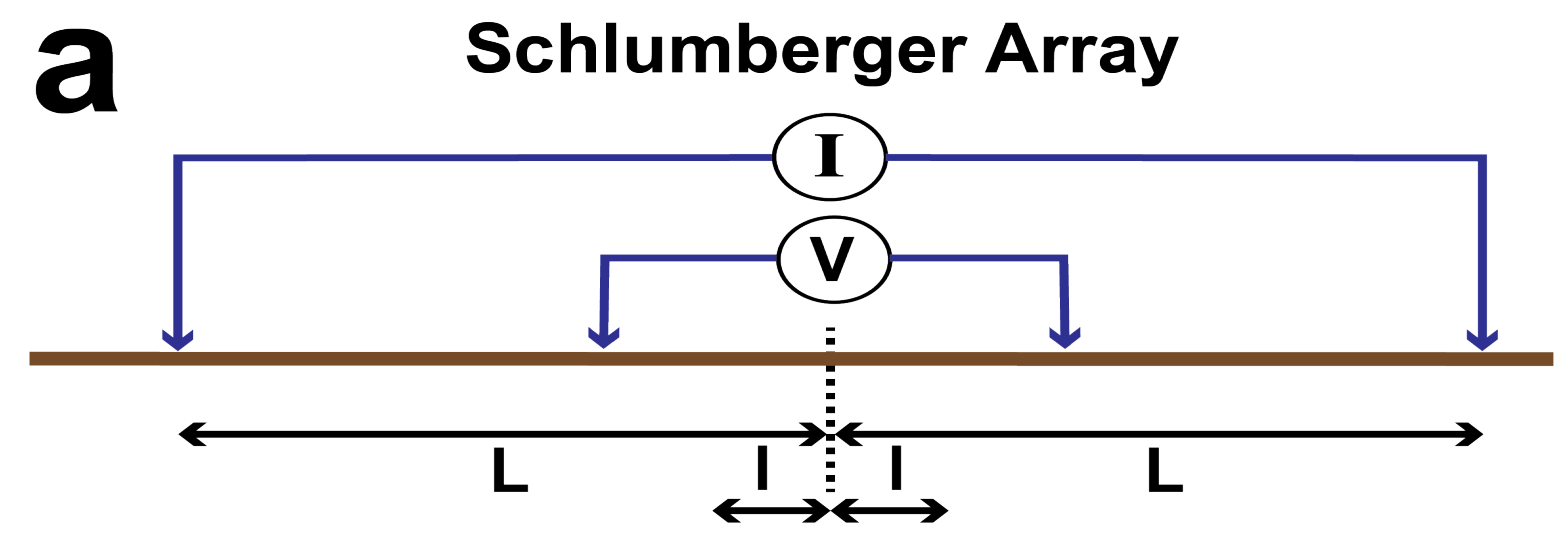

\section{Dipole-Dipole Array}

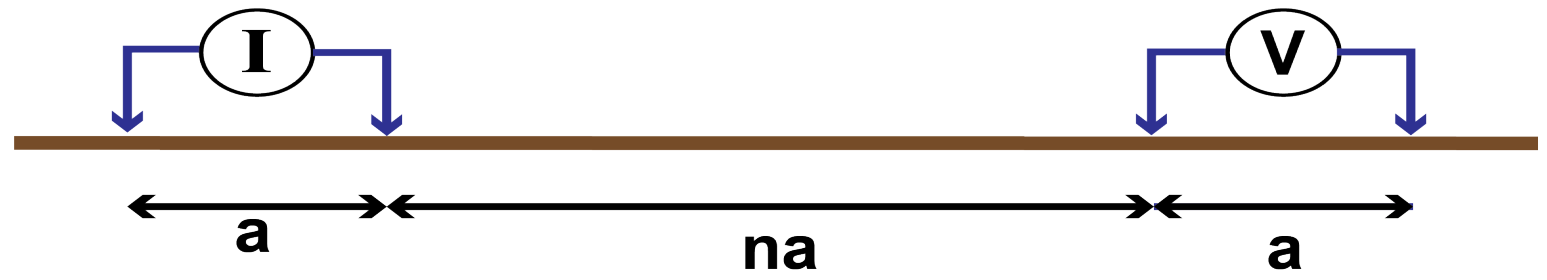

Figure 4. Schematics of the standard electrical resistivity configurations used in this study. a. Schlumberger array. b. Dipole-dipole array. 


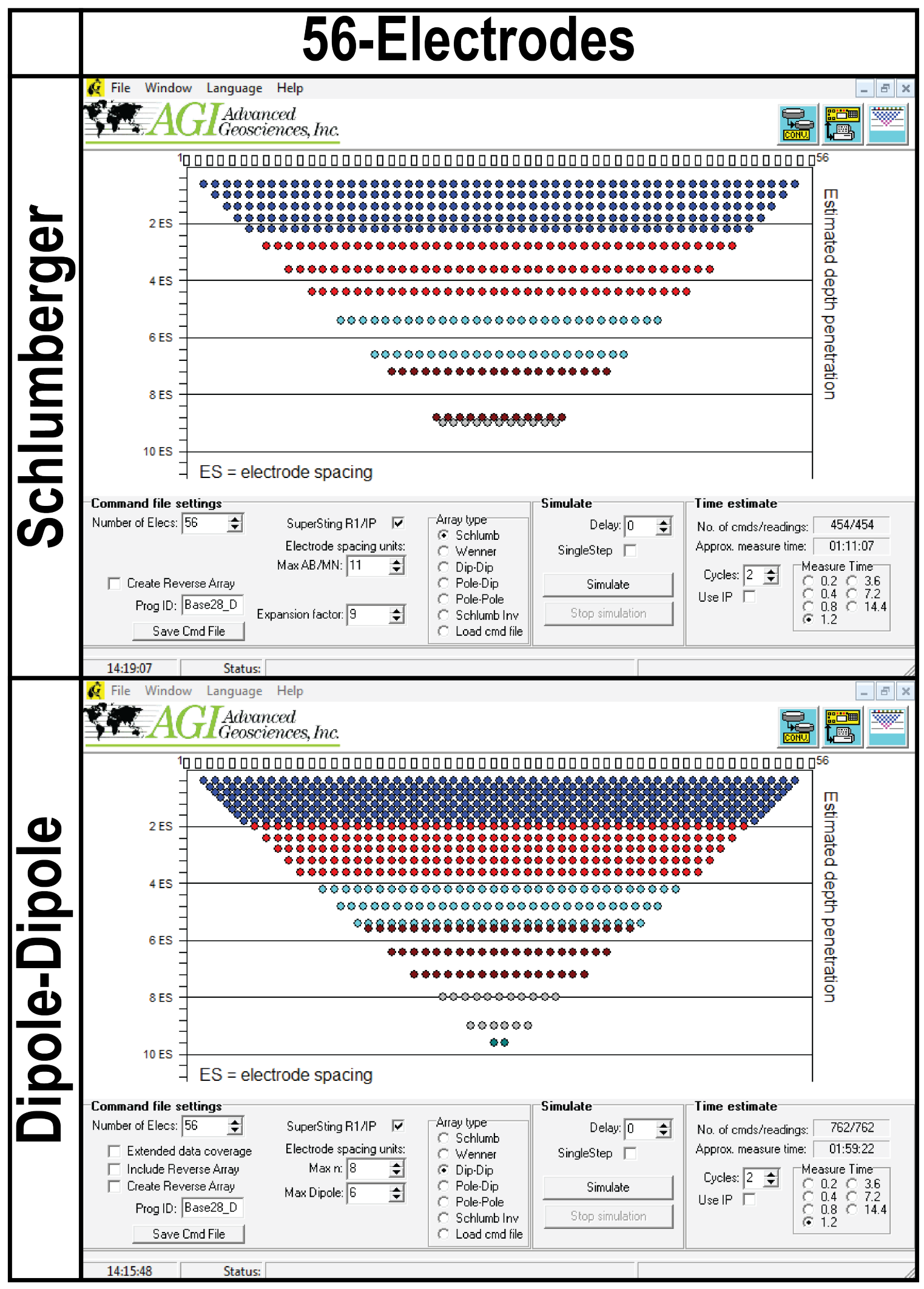

Figure 5. AGI command creator windows showing Schlumberger and dipole-dipole command file configurations for 56 electrodes (Advanced Geosystems, Inc., 2007). 
The next step is to try to find a model of subsurface distribution of resistivity that would produce a data set sufficiently similar to the calculated impedances that make up our collected data set given the same configurations of current and voltage electrodes, constrained by a priori understanding of the subsurface geology. This iterative process is known as inverse theory. Finally, we consider the geological ramifications of the resistivity distribution within our model.

Resistivity in the subsurface can be affected by a number of factors including lithology, porosity, permeability, fluid chemistry, fluid saturation, temperature, and mineralogy. Within the context of these parameters and the understanding of local geology, the subsurface distribution of resistivity is interpreted.

\section{Data \& Methods}

\subsection{Electrical Resistivity (ER) Equipment}

All ER measurements were collected with the Advanced Geosciences, Inc. (AGI) SuperSting ${ }^{\mathrm{TM}} \mathrm{Wi}-\mathrm{Fi} \mathrm{R} 1$ resistivity portable geoelectrical imager, which was used with AGI's passive multi-electrode cables and electrode relay switch box. The cables are designed such that each electrode is connected to the switch box by its own conductor. The switch box simply switches to the electrodes needed for each measurement taken during the collection of data indicated for a specific array. Each cable consists of 14 electrodes spaced 6.25 m apart. Multiple cables can be conjoined, thus enabling the deployment of longer lines. We deployed single-, double-, and quadruple-lines consisting of 14, 28, and 56 electrodes and with lengths of 84, 168, and 336 meters, respectively. 
The AGI SuperSting ${ }^{\mathrm{TM}}$ uses command files that define and communicate which array is to be used. The unit comes preloaded with command files for arrays consisting of 14 electrodes. Command files consisting of more electrodes need to be created and loaded by the user. We created Schlumberger and dipole-dipole command files for both 28 and 56 electrodes (Fig. 5).

Figure 5 shows a schematic of the ER equipment setup. The electrode cable is rolled out as straight as possible and should be situated so it is relatively centered across a feature of interest. Then, the cable is connected to the switch box, which is connected to the AGI SuperSting ${ }^{\mathrm{TM}}$. For single- and

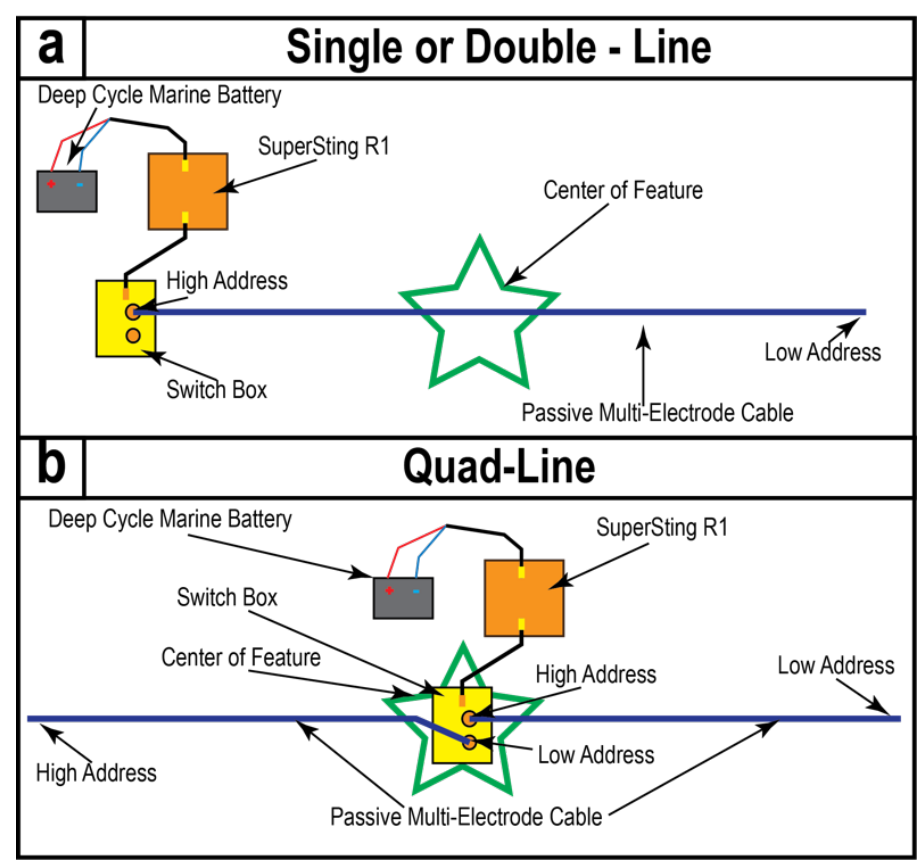

double- lines the cable end nearest the highest addressed electrode

Figure 6. Electrical resistivity schematics a. singleor double-line schematic b. quad-line schematic.

(i.e., electrode 14 or 28) is connected to the switch box. For a quad-line, the switch box and AGI SuperSting ${ }^{\mathrm{TM}}$ are centered between two sets of two conjoined cables where both the end nearest the highest address of the first set and end nearest the lowest address of the second set are connected to the switch box.

Once a line is established, two tests are conducted before deployment of an array. First, a switch test checks if there is communication between each electrode, 
the switch box, and AGI SuperSting ${ }^{\mathrm{TM}}$. Second, a contact resistance test measures the contact resistance between each pair of neighboring electrodes along the entire length of cable. Contact resistance values less than $7 \mathrm{k} \Omega$ were considered sufficient to proceed with deployment and any value less than $2 \mathrm{k} \Omega$ was regarded as excellent.

\subsection{Electrical Resistivity Deployment Locations}

Two surface features of interest, location 1 and location 2 , were identified on Cave Hill for the deployment of ER lines (Fig. 6). Location 1, a karstic swale, was identified as a possible location of unknown void spaces, and as a target that could potentially provide insight to the connection between bedrock structure and water flow patterns. Location 2 is a sinkhole located above known cave passages, and was identified as a possible location of a perched aquifer as outlined in the introduction.

Seven single-lines were placed through and near location 1 (Fig. 7). Two lines, SW01 and SW02, were laid approximately perpendicular to and across the feature. Two additional lines, SW03 and SW04, were situated approximately perpendicular to the feature and slightly north of its northern apex. Three lines approximately parallel to the feature, SW05, SW06, and SW07, were laid through the center of and adjacent to the feature to the west and east respectively. All lines at location 1 were deployed during relatively dry conditions.

Three lines, including a single, a double and a quad-line, were centered on the sinkhole at location 2 (Fig. 8). Using a roughly northeast-southwest directed single-line, six sets of Schlumberger and dipole-dipole arrays, GCDD01-06, were collected at approximately thirty minute intervals during and directly following a 
rainstorm. Two additional lines, GCDD09, which was a quad line running roughly northeast-southwest and GCDD10, which was a double-line running roughly eastwest, were centered on the sinkhole at location 2 during relatively dry conditions. A second sinkhole was also crossed by the northern section of line GCDDO9.

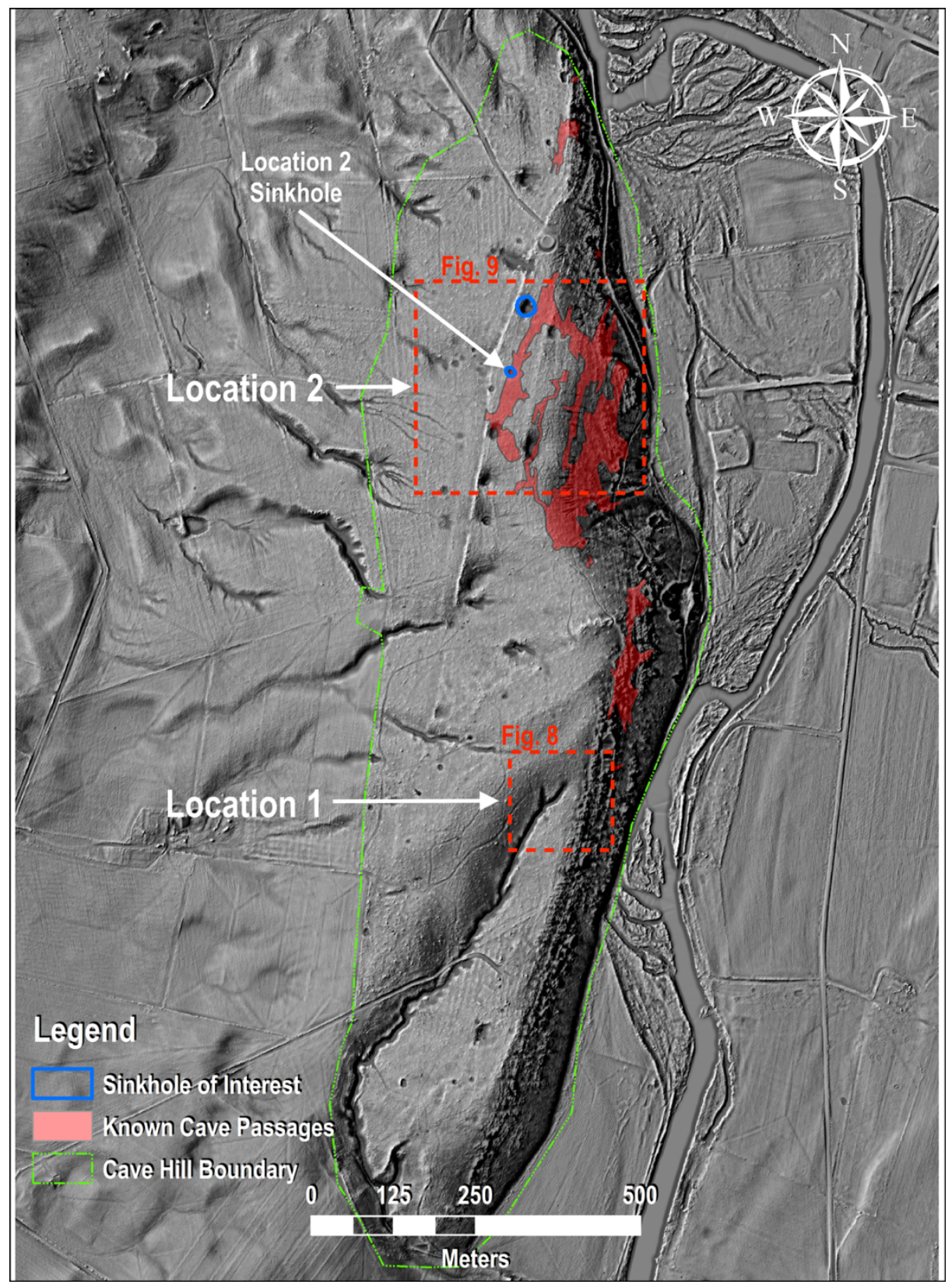

Figure 7. Locations of two surface features of interest on Cave Hill. Background image is a hillshade + topographic position index map provided by Daniel Doctor of the U.S. Geological Survey (adapted from USGS, 2016, unpublished LiDAR [image/data]). Known cave passages overlay courtesy of Daniel Doctor of the U.S. Geological Survey. 


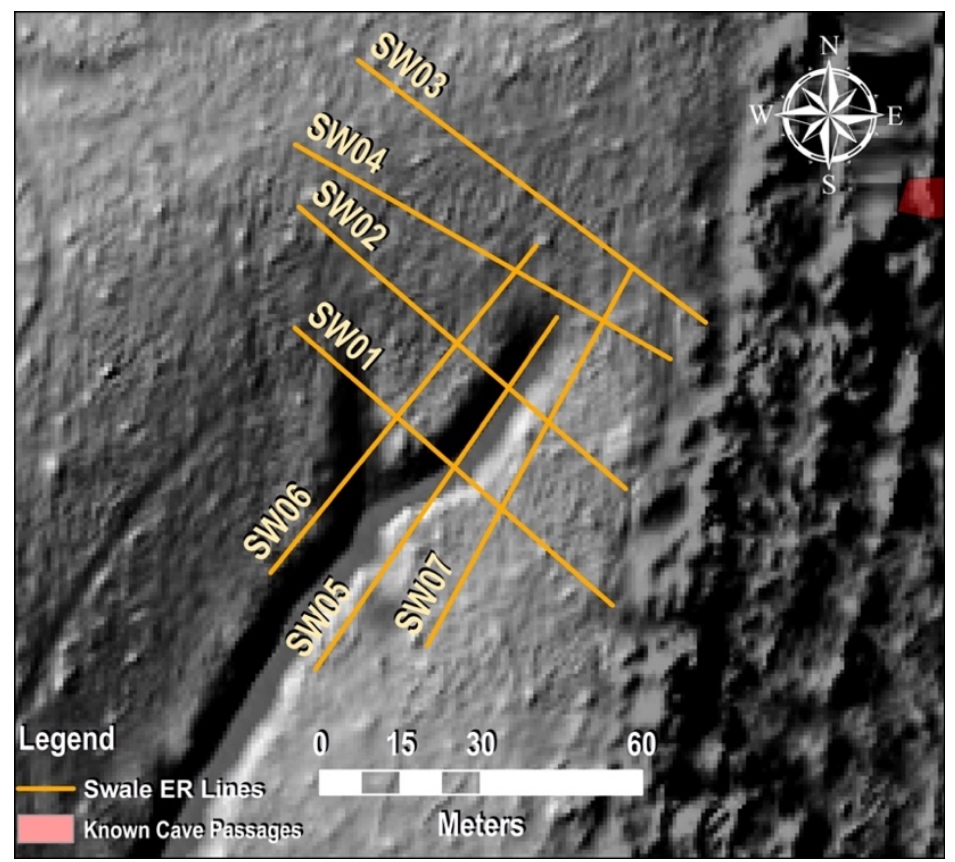

Figure 8. ER lines deployed at location1. All are single-lines situated approximately parallel and perpendicular to the swale feature. Background image is a hillshade + topographic position index map provided by Daniel Doctor of the U.S. Geological Survey (adapted from USGS, 2016, unpublished LiDAR [image/data]). Known cave passages overlay courtesy of Daniel Doctor of the U.S. Geological Survey.

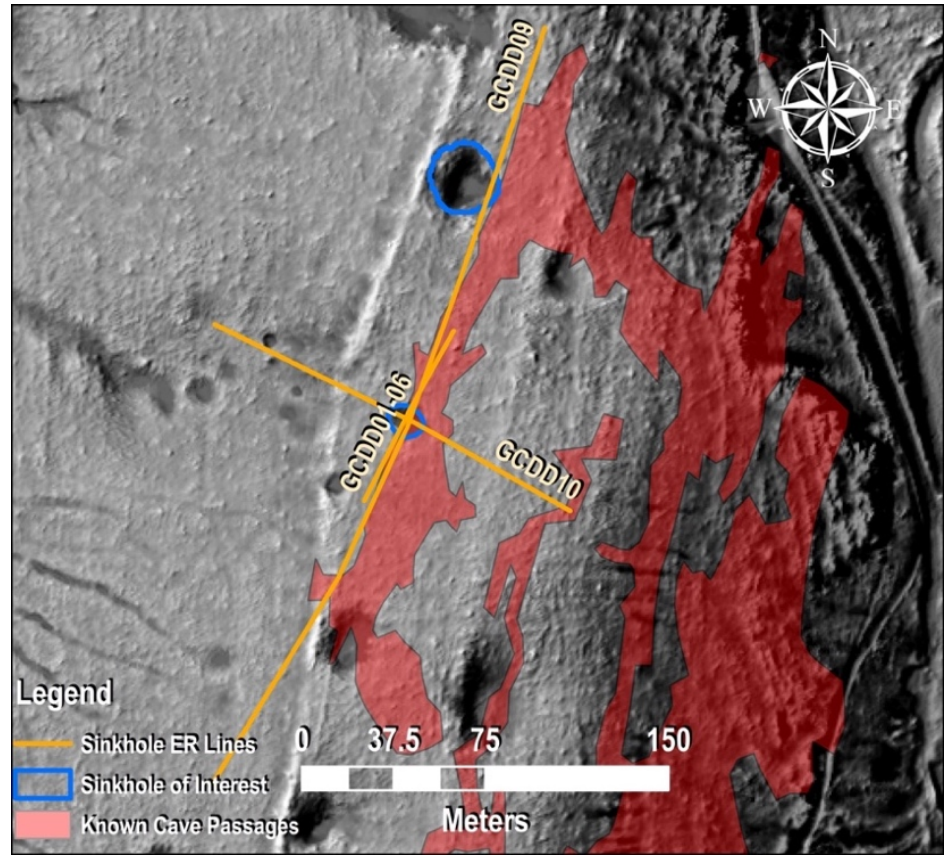

Figure 9. ER lines deployed at location 2. All lines are centered over the primary sinkhole of interest. GCDD01-06, GCDD09. and GCDD10 are a single-, quad-, and double-line, respectively. Background image is a hillshade + topographic position index map provided by Daniel Doctor of the U.S. Geological Survey (adapted from USGS, 2016, unpublished LiDAR [image/data]). Known cave passages overlay courtesy of Daniel Doctor of the U.S. Geological Survey. 
For most ER lines deployed in this project, coordinates and elevation were collected at each electrode location using a Leica Zeno 20 GPS unit (Leica Geosystems). The Zeno 20 can obtain horizontal accuracy as little as $1 \mathrm{~cm}$ and vertical accuracy of approximately three times the achieved horizontal accuracy. We were not able to collect GPS data for the first two lines at location 1 (SW01 and SW02) due to a malfunctioning and badly outdated GPS unit; the Zeno 20 was purchased in part as a response to this issue. While the new unit generally was able to collect good data for most of the electrode locations, obstructions due to weather or tree foliage complicated this issue. The suspect electrode locations and all elevation values were interpolated by using a $1 \mathrm{~m}$ high resolution airborne LiDAR-derived DEM provided by Daniel Doctor of the U.S. Geological Survey (adapted from USGS, 2016, unpublished LiDAR [image/data]) in Esri ArcGIS (Esri, Inc., 2013).

Points for the electrode positions of location 1 lines SW01-02 were placed by best recollection and the aid of the measure tool and are therefore less certain. Due to low horizontal accuracy $(>1 \mathrm{~m})$ of the acquired GPS data, some points along line SW03-06 were also repositioned with respect to the neighboring points. Relative locations of missing points along location 2 line GCDD09 were added by measuring horizontal distance from the closest collected point, while attempting to maintain approximate electrode spacing. Horizontal coordinates did not need to be adjusted for SW07, GCDD01-06, and GCDD10. For all ER lines, elevation data at each point were extracted from the DEM acquired from the USGS. Appendix B contains 
complete tables of measured point coordinates and elevations, interpolated points, and interpolated elevations.

\subsection{Electrical resistivity data processing}

Measured ER data was processed using AGI's EarthImager 2D Resistivity and IP Inversion Software (Advanced Geosciences, Inc., 2007). We preformed inversions on the Schlumberger and Dipole-Dipole data sets individually, and also on merged data sets that combined data from both arrays. The merged inversions gave better results (not unexpectedly), and we present only these.

We ran smooth model finite element inversions using Cholesky composition to solve the forward equation. We used eight mesh divisions between electrodes. The misfit parameters (RMS error and L2 norm) varied depending on the individual inversion.

While we passed all of the data through a spike removal filter as part of standard practice, two lines (SW05 and SW06) were sufficiently noisy (as determined by a cross plot of measured and predicted apparent resistivity, relative data misfit pseudosection, and data misfit histogram (Appendix C)) to require a second phase of removal of misfit data.

\subsection{Structural Geology and Geospatial Investigation}

Strike and dip measurements were obtained from 17 rock outcrops on Cave Hill. Observations of rock type and other notable characteristics such as sedimentary structure, fold patterns, and proximity to cave entrances were recorded at each location. The strike and dip data were imported into Stereonet 9.9 
(Allmendinger, Cardozo, and Fisher, 2013; Cardozo, and Allmendinger, 2013) to generate two stereonets that approximate trend and plunge of two fold axes (Fig. 9). Data were plotted as poles, the cylindrical best fit was found between the poles, then the regional fold axes were found.

Two elevation profiles across Cave Hill and perpendicular to the fold axis were exported from the Global Multi-Resolution Topography (GMRT) Grid Version 3.3 (Ryan et al., 2009) in GeoMapApp (Marine Geoscience Data System, 2013, [http://www.geomapapp.org]), which were used with the structural data to draw two cross-sections, B-B' and A-A', near the ER survey locations 1 and 2, respectively (Fig. 10). Several outcrops were present near location 2, which allowed crosssection A-A' to be developed without considering the plunge of the western fold axis; however, there were insufficient exposures near location 1 to complete an independent cross-section (B-B') there.

Since the southwestern fold axis was determined to have significant plunge, elevations at strike and dip locations needed to be corrected before they could be projected into cross-section B-B' (Appendix D). Point elevations were corrected by first finding the distance $d$ from the point, with respect to the trend of the eastern fold axis, to the cross-section profile. This was accomplished with a ruler and a scaled map of point and cross-section profile locations. The converted elevation $h^{\prime}$ is then the difference of the measured elevation $h$ and change in elevation $\Delta h$ along $d$. By letting $\Delta h=d \tan \alpha$ where $\alpha$ is the angle of the fold axis, then,

$$
h^{\prime}=h-\Delta h=h-d \tan \alpha
$$



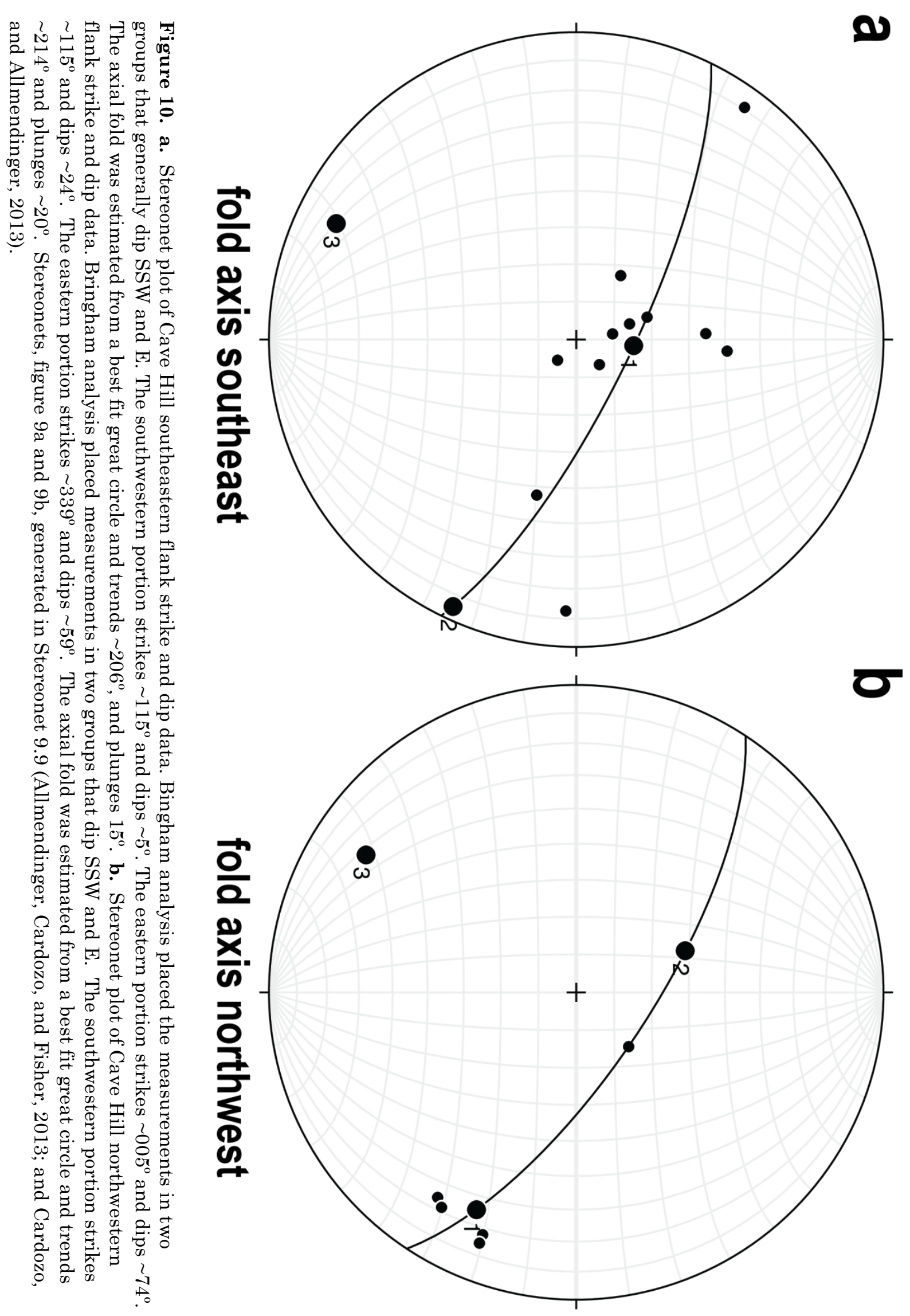


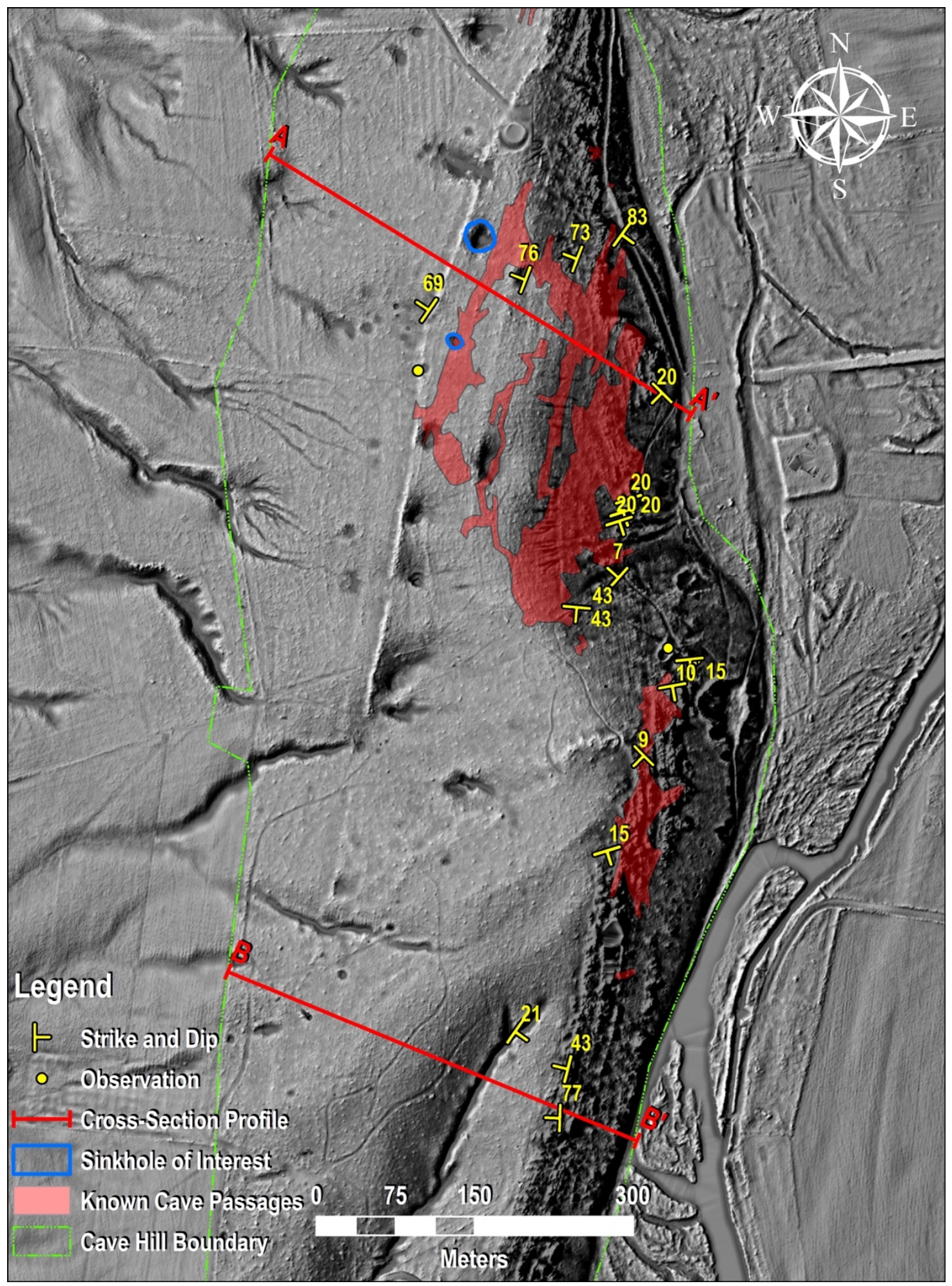

Figure 11. Strike and dip measurements and observations where used to develop two crosssections, B-B' and A-A', near study locations 1 and 2 respectively, to be correlated with surface features and ER data. Background image is a hillshade + topographic position index map provided by Daniel Doctor of the U.S. Geological Survey (adapted from USGS, 2016, unpublished LiDAR [image/data]). Known cave passages overlay courtesy of Daniel Doctor of the U.S. Geological Survey. 


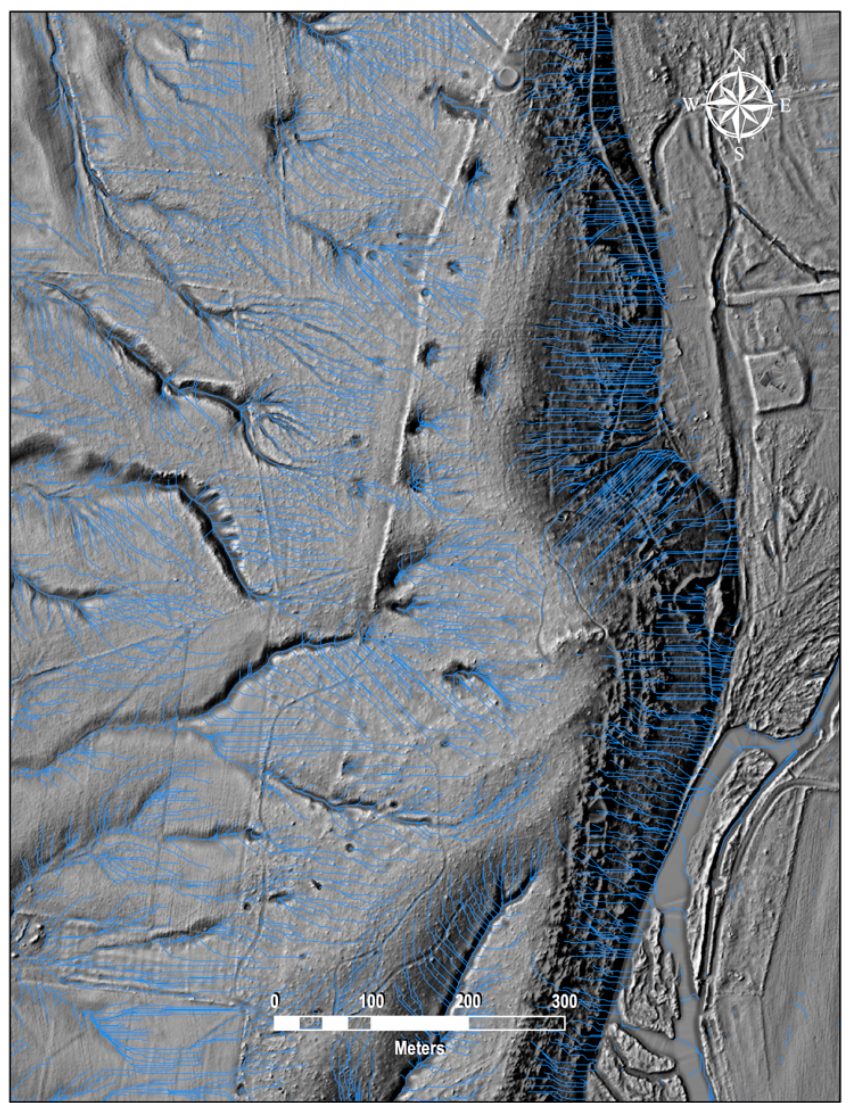

Figure 12. Polylines, created from an aerial LiDAR-derived DEM, representing the pathways that surface water is likely to take on Cave Hill. The GIS tools used, find pathways by the change in elevation between neighboring cells, and by weighting each cell by how much it contributes to downstream flow. Background image is a hillshade + topographic position index map provided by Daniel Doctor of the U.S. Geological Survey (adapted from USGS, 2016, unpublished LiDAR [image/data]).
The DEM provided by Daniel Doctor

of the U.S. Geological Survey (adapted from USGS, 2016, unpublished LiDAR [image/data]) was used in ArcGIS to create a polyline file representing the paths in which surficial water flows on Cave Hill (Fig. 11). This was accomplished with the Flow Direction and Flow Accumulation tools found within the Spatial Analyst tool box. First, the DEM was input into Flow Direction, which uses a nearest neighbor technique based on the largest change in elevation between neighboring cells to output a raster dataset representing the direction surface water is most likely to flow between cells. Next, the output of Flow Direction was used as input into Flow Accumulation which outputs a raster weighting based on how much each cell is contributing to downstream flow. From the output, cells that contributed to surficial flow were converted into polylines. The polyline result was used with a hillshade + TPI map acquired from Daniel Doctor of the U.S. Geological survey (adapted from USGS, 2016, unpublished 
LiDAR [image/data]) and the cross-sections to correlate the inverted ER profiles with the surface features.

\section{Results}

\subsection{Location 1, Electrical Resistivity}

Measured and calculated apparent resistivity pseudosections and merged Schlumberger and dipole-diploe inverted resistivity sections for each deployment at location 1 can be found in Appendix E. The maximum depth achieved with the single 14 electrode cable was slightly less than 20 meters.

All inversion models for NW to SE ER deployments (SW01M-04M) converged within six iterations with RMS $\leq 2.93 \%$ and L2 values 0.96 . SW01M produced a large contrast in resistivity values (16.0-24,311 $\Omega \mathrm{m})$ that are considerably different than the lower resistivity values yielded by SW02M-04M (41.7-8,485 $\Omega \mathrm{m})$; however, the resistivity structure is generally consistent between sections SW01M-04M.

SW04M contains characteristics common throughout the NW to SE ER deployments (SW01M-04M) (Fig. 12). Shallow depths ( 5-10 m) below the depicted topographic surface consists of average background resistivity values $(\sim 600 \Omega \mathrm{m})$. Horizontal to sub-horizontal oblong pockets of conductive materials $(\leq 250 \Omega \mathrm{m})$ are present within the background (Fig. 12, [A]). Smaller and more-ovoid patches of moderately-high resistivity materials $(<1000 \Omega \mathrm{m})$ are situated adjacent to the conductive features (Fig. 12, [B]). Deeper in the subsurface (> 5-10 m), the resistivity structure becomes layered such that resistivity increases rapidly with depth while remaining laterally homogenous (Fig. $12[\mathrm{C}]$ ). 


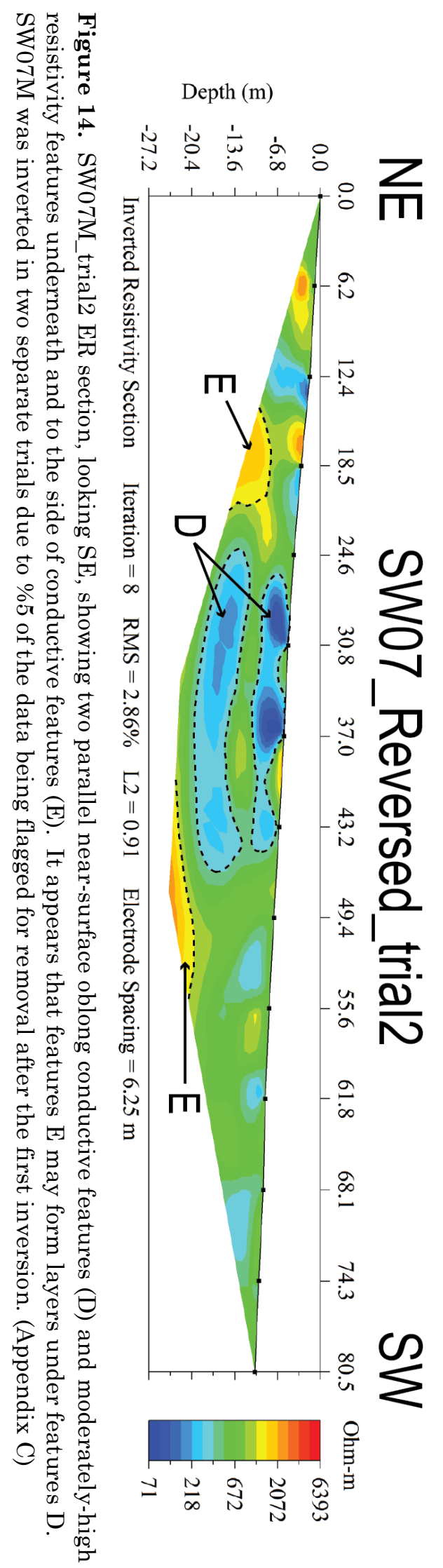

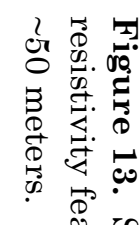
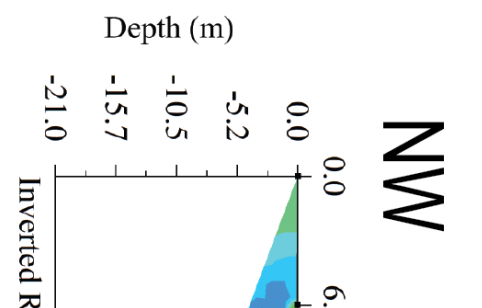

है

赵. 苨

م

造.

号.

प

궁

总.

赵

$\stackrel{+\infty}{\circ}$

苗

官空

ज丞

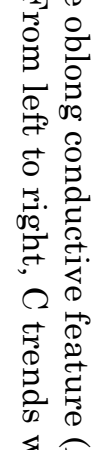

廷

官

की

藏

¿

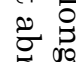

吾芒

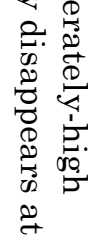
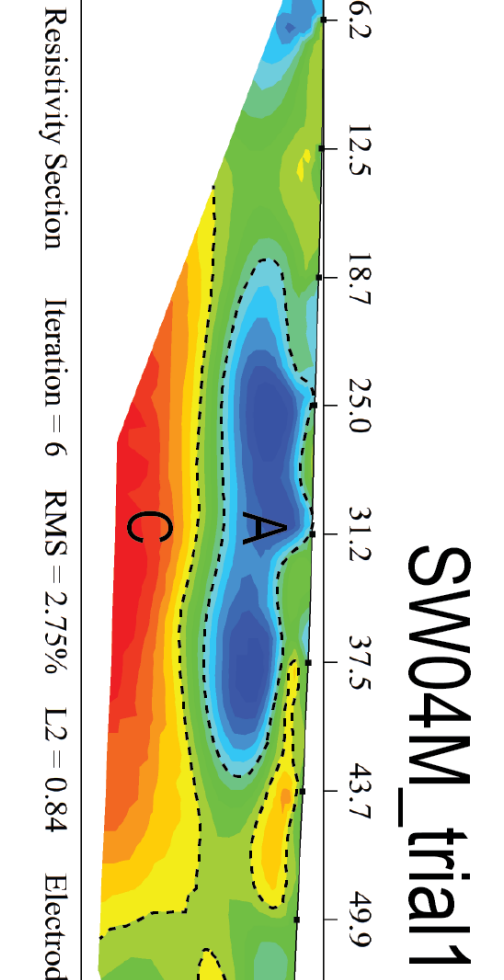

व

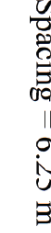
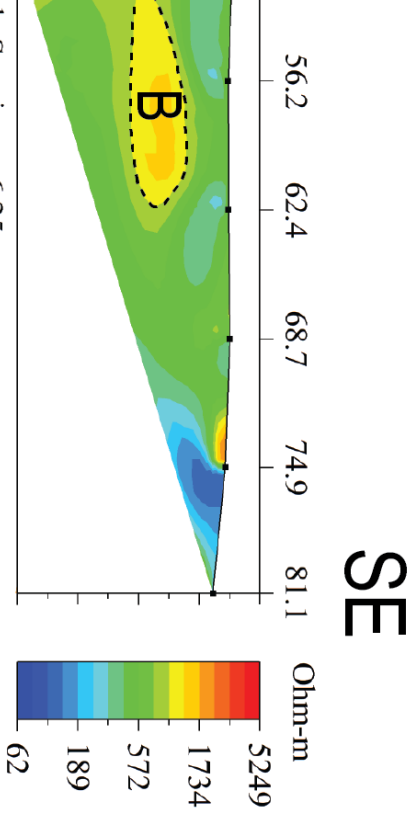
Models for NE to SW ER deployments (SW05M-07M) converged between eight and eleven iterations with RMS $\leq 3.64 \%$ and L2 values $\leq 1.47$. The models exhibit an extreme contrast in resistivity values $\left(16.5-4 \cdot 10^{5} \Omega \mathrm{m}\right)$. These sections are structurally similar to their NW to SE counterparts; however, each contain one or more unique differences. SW05M is absent of resistive near-surface materials; also, layering at depth directly opposes topography and is confined to one area between 24 and 43 meters on the horizontal axis. Both SW05M and SW06M have a single conductive layer $(<200 \Omega \mathrm{m})$ extending the entire length of their section with a vertical thickness of approximately seven meters. SW07M has two oblong conductive layers $(<250 \Omega \mathrm{m})$ oriented parallel to and above each other (Fig. 13, [D]). These features are $\sim 19.5 \mathrm{~m}$ in length and are separated by $\sim 3.5 \mathrm{~m}$ of background material ( 672 $\Omega$ m). Layering, in SW07, appears to be "cradling" the two oblong features, but there was insufficient depth penetration to reveal the full extent of this layering (Fig. 13, [E]).

\subsection{Location 2, Electrical Resistivity}

Measured and calculated resistivity pseudosections and merged Schlumberger and dipole-dipole inverted resistivity sections for each deployment at location 2 can be found in Appendix F. The maximum depths achieved were approximately 17 meters, 80 meters and 34 meters, for the single-, quad- and double- lines, GCDD01-06, GCDD09, and GCDD10, respectively.

The inversion models for the NNE to SSW ER line deployed over approximately 30 minute intervals during and directly after a precipitation event 
(GCDD01M-06M) converged at three iterations with RMS percentages $\leq 2.77$ and L2 values $\leq 0.85$. All six models show a moderate and nearly identical resistivity contrast (190-5,527 $\Omega \mathrm{m})$ and no structural differences between the ER sections. This suggests that the transit of water through the upper-subsurface ( 0 -12 m) occurs on timescales greater than the length of time in which the measurements were taken ( $\sim 6$ hours). The dataset may not be able to be used to track the transit of water in "real time," but it will help in validating the ER sections generated from the other deployments at this location. The models GCDD01M-06M will be referred to as a singular object for the remainder of the paper.

There is little difference in the resistivity structure between sections GCDD01M-06M and GCDD10M. Only the results of GCDD01-06M are discussed here, and refer to Appendix F for GCDD10. For GCDD01-06 (Fig. 14), the uppersubsurface $(<7 \mathrm{~m}$ depth) contains several horizontally oriented conductive oblong features $(<500 \Omega \mathrm{m})$ (Fig. 14, [F]). One feature ( 31 by $3.5 \mathrm{~m})$ extends entirely across the northeastern-half of the ER section and abruptly disappears at the NE edge of the sinkhole feature. A second smaller conductive feature ( 7 by $2 \mathrm{~m})$ is situated at the SE edge of the sinkhole. Below the conductive features $(\sim 7 \mathrm{~m}$ depth), a moderately-high resistive layer $(\sim 2,000 \Omega \mathrm{m})$ extends the entire length of the model mimicking topography, including the sinkhole (Fig. 14, [G]). Below the resistive layer and on either side of the sinkhole, are two resistive ovoid-shaped features $(\sim 3,000-5,455 \Omega \mathrm{m})$ oriented such that their major axes are parallel to the sides of the sinkhole (Fig. 14, $[\mathrm{H}]$ and $[\mathrm{J}])$. A homogenous resistive mass $(\sim 2,500$ 
$\Omega \mathrm{m}$ ) fills the spaces between the ovoid features (Fig. 14, [I]). The inversion model of the double-line GCDD10M shows the same pattern occurring perpendicular to GCDD01M-06M.

The three inversion model trials for the NNE to SSW 56 electrode quad-line (GCDD09M) converged at ten iterations with RMS percentages $\leq 3.63$ and L2 values $\leq 1.46$. GCDD09M produced resistivity contrasts far surpassing any ER data set acquired for this project. The maximum resistivity threshold setting was increased each trial until resistivity values no longer increased. This setting adjusts the range of the values to be displayed in the inverted ER section by assigning any resistivity values that are greater than the threshold value to the color value depicting the selected maximum resistivity. When the range of resistivity values become large, like in GCDD09, the typical smaller contrasts between different features may be assigned the same color value within the section; thus, hindering their visual, not numerical, representation from the result. Trial1 and trial2 reached the resistivity limit defined as $1 \cdot 10^{5}$ and $1 \cdot 10^{6} \Omega \mathrm{m}$ in the inversion settings for trial1 and trial2, respectively. In trial3, resistivity reached a maximum value $6.8 \cdot 10^{6} \mathrm{\Omega m}$. Minimum resistivity was close to the lowest values among all project lines from both locations $(27-28 \Omega \mathrm{m})$. Although, trial2 and trial3 show the limits of the resistivity values, the extremely high values are limited to a few small features in the section and most features within the section are less than $1 \cdot 10^{5} \Omega \mathrm{m}$; therefore, trial1 seems to preserve the best visual representation of the subsurface geometry due to the smaller range of values within the color scheme. 

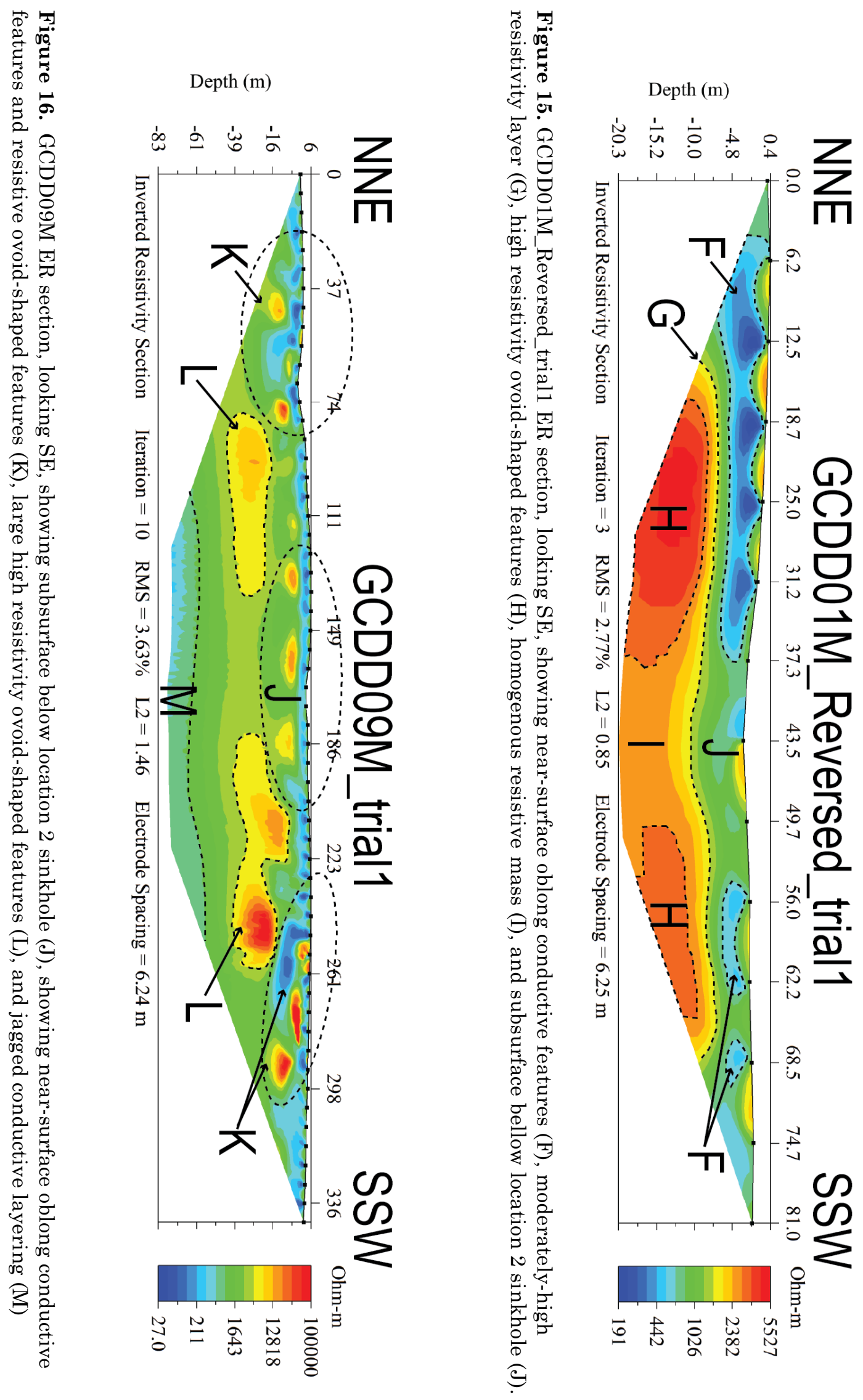
GCDD09M (Fig. 15) achieved depth penetration four times greater than the single lines ( $\sim 80 \mathrm{~m})$. The upper-subsurface ( $<7 \mathrm{~m}$ depth) contains a band ( $\sim \mathrm{m}$ thick) of horizontally to sub-horizontally oriented conductive oblong features $(<500$ $\Omega \mathrm{m})$ (Fig. 15, $[\mathrm{K}]$ and $[\mathrm{J}]$ ). The angle of orientation of the conductive bands become steeper $\left(\sim 15^{\circ}-60^{\circ}\right)$ and thickness generally increases ( $\sim 8 \mathrm{~m}$ thick) from topographic high areas towards sinkhole features at which they plunge to deeper depths ( $20 \mathrm{~m}$ depth) (Fig. 15, [K]).

As seen in GCDD01-06M, resistive ovoid shaped features ( 3,000-15,000 $\Omega \mathrm{m})$ are oriented under the conductive bands ( 10-16 m depth) such that their major axes ( 6-10 m length) are parallel to the sides of the sinkhole (Fig. 15, [K]). However, the greater depth penetration of quadline-GCDD09 reveals ( $16-50 \mathrm{~m}$ depth) larger ovoid features ( 30-50 m length) with higher resistivity $\left(\sim 3 \cdot 10^{3}-1 \cdot 10^{5}\right.$ Sm) (Fig. 15, [L]). Unlike GCDD01-06M, there is an area on the southwestern side of the section where there are two extremely-resistive ovoid features $\left(\sim 6.8 \cdot 10^{6} \Omega \mathrm{m}\right)$ oriented above the shallow conductive bands (Fig. 15, $[\mathrm{K}]$ ). The bottom of the GCDD09M section (> $50 \mathrm{~m}$ depth) has relatively homogeneous resistivity ( 1,600 $\Omega \mathrm{m})$. However, jagged conductive layering $(27-300 \Omega \mathrm{m})$ is present in the deepest portions ( 61-83 m depth) (Fig. 15, [M]).

\subsection{Structural Geology and Geospatial Investigation Results}

The stereonets (Fig. 9) suggest the fold axis on the southeastern flank of Cave Hill, near location 1 , trends $\sim 206^{\circ} \mathrm{SSW}$ and plunges $\sim 15^{\circ}$, while the fold axis on the western flank, near location 1 , trends $\sim 214^{\circ} \mathrm{SSW}$ and plunges $\sim 20^{\circ}$. 
The observations recorded suggest that bedrock near location 1 primarily consists of algal laminated dolostone and mic-sparite; however, data at this location were limited, especially west of the swale feature. Structure of the southern portion of Cave Hill was found to consist of three higher-order folds within an overall anticline (Fig. 16a). Parasitic folding was also observed in algal laminated dolostone on the southeastern flank near location 1 (Fig. 16b). The swale feature cuts through a syncline at the study location. Further South $(\sim 80 \mathrm{~m})$, the swale feature deviates westward from strike $(\sim 30 \mathrm{~m})$ and begins to cut through the antiform axial fold.

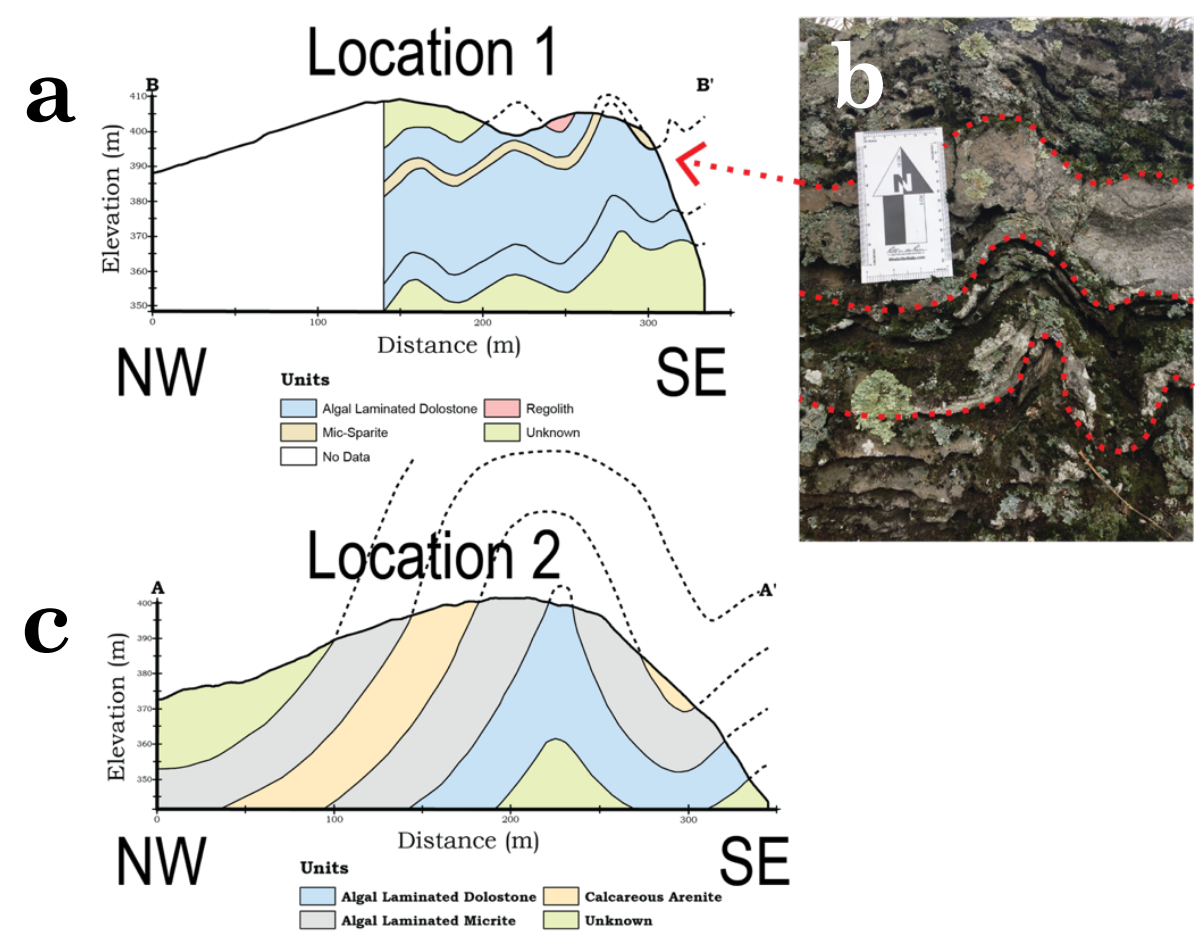

Figure 17. a. Cross-section B-B' shows high-order folding within an overall anticline. b. Parasitic folding observed in dolostone near location 1. c. Cross-section A-A' shows sub-vertical bedding and an overall anticline. Profiles, figure 16 a and c, after profiles exported from the Global MultiResolution Topography (GMRT) Grid Version 3.3 (Ryan et al., 2009) in GeoMapApp (Marine Geoscience Data System, 2013, [http://www.geomapapp.org]). 


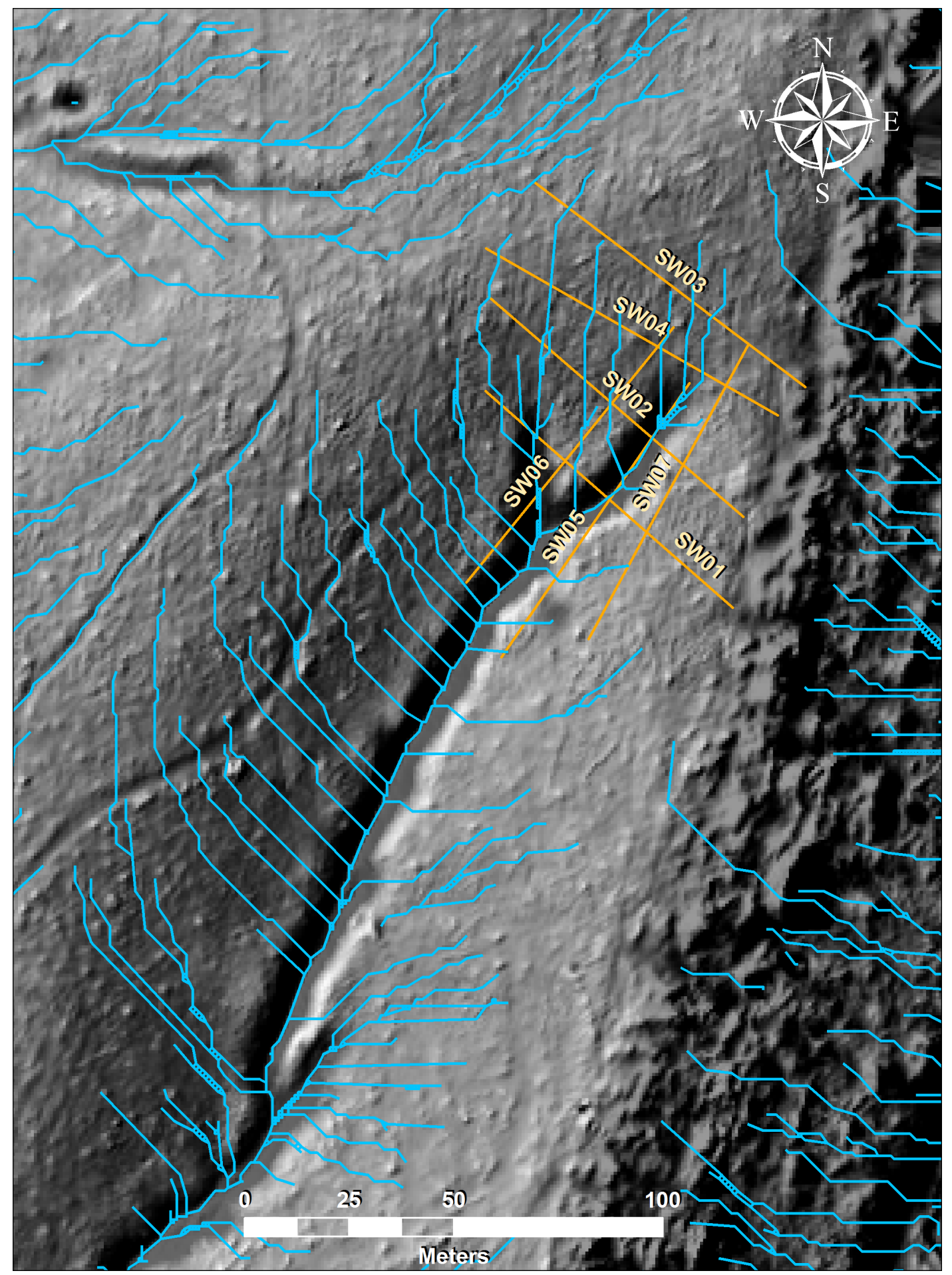

Figure 18. Stream model for location 1 showing direction of surface water flow into the karstic swale. The majority or surface water appears to enter the swale from the northwest, then the swale carries it SSW off Cave Hill and into local streams below. Electrical resistivity survey lines are labeled and shown by orange lines. Background image is a hillshade + topographic position index map provided by Daniel Doctor of the U.S. Geological Survey (adapted from USGS, 2016, unpublished LiDAR [image/data]). 


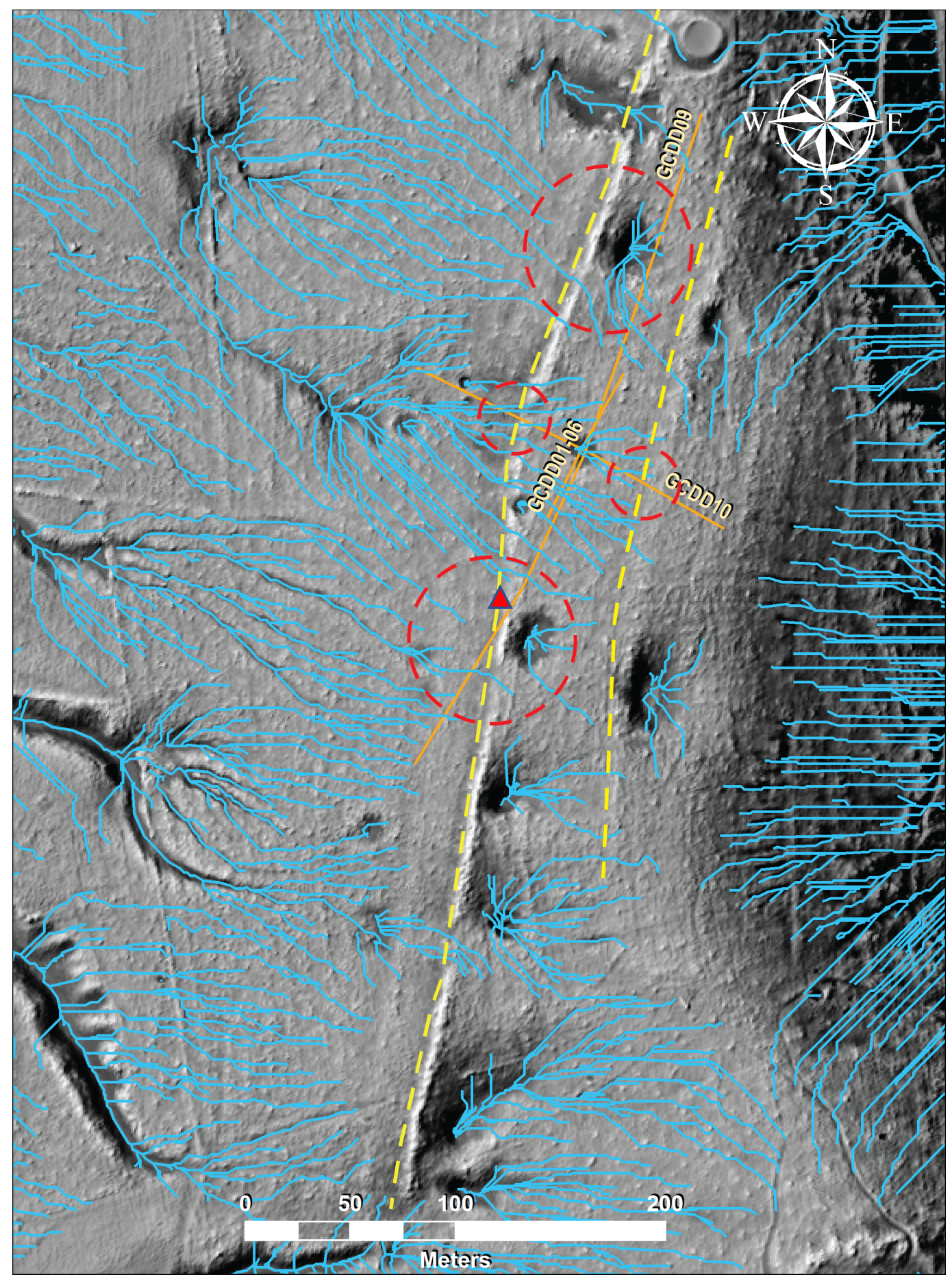

Figure 19. Stream model for location 2 showing direction of surface water flow into sinkholes along a calcareous arenite ridge to the west and suspected dolostone ridge to the west. Electrical resistivity survey lines are labeled and shown by orange lines. The confining ridges are marked by dashedyellow lines. Sections where survey lines go over or become close to ridges are circled by red-dashed circles. The triangle marks the location of calcareous arenite outcrop in which a strike and dip measurements were recorded. Background image is a hillshade + topographic position index map provided by Daniel Doctor of the U.S. Geological Survey (adapted from USGS, 2016, unpublished LiDAR [image/data]). 
The observations recorded found that bedrock near location 2 consists of algal laminated micrite, algal laminated dolostone, and calcareous arenite. Bedrock is sub-vertical, and was found to be an overall anticline with no higher-order folding observed (Fig 16c). A thick bed of micrite located between calcareous arenite to the West and algal laminated dolostone to the East lies under the ER deployment area. Survey GCDD09 crossed diagonally $\left(\sim 20^{\circ}\right)$ over the arenite bed.

The artificial streams generated from the DEM indicate that surface water flows into the swale feature (location 1) primarily from the northwest (Fig. 17). The swale deviates the surface water along strike to the SSW where it is able flow freely into a local stream. Surface water at location 2 flows to the northwest (Fig. 18); however, the calcareous arenite ridge, identified both in the field and with the aid of a hillshade + TPI map, appears to block most surface water from flowing directly into local streams. Instead, surface water is forced into the subsurface through sinkholes located along the eastern side of the ridge. There is also a second parallel ridge located to the East $(\sim 70 \mathrm{~m})$ that appears to be acting in the same manner. This ridge was undetected by the field investigation, and an observation of micrite was even made in a sinkhole directly against contact with the ridge. The westward dipping dolostone/micrite contact portrayed on the cross-section (Fig. 16c) was logically placed based on the orientation of the other units.

\section{Interpretations \& Discussion}

\subsection{Location 1, Karstic Swale}


The perpendicular and parallel inverted resistivity sections together with the surficial water flow patterns, deciphered from the DEM, and structural geometry of the bedrock gives valuable insight on the water flow patterns into the karstic swale. The entire extent and geometry of features could not be observed at this location due to the shallow depth penetration $(\sim 20 \mathrm{~m})$ of the short 14-electrode ER lines. However, the data is robust enough to interpret groundwater behavior. It suggests that source of groundwater beneath the swale feature's northern apex is sourced from locations between the east and north, and input of westerly sourced water to this location is blocked by some material and/or factor that is not observable by electrical resistivity.

The highly conductive $(<200 \Omega \mathrm{m})$ oblong-features seen throughout the ER sections in the upper-subsurface $(<12 \mathrm{~m}$ depth) are indicative of water-saturated permeable carbonates in the epikarstic zone, which Williams (1983) defines as the uppermost zone in the subsurface of a karst landscape where dissolution has occurred and is ongoing. Further infiltration of water into the water table is hindered by surrounding carbonates that are minimally permeable, have few or no karst features, and are of moderate-resistivity $(\sim 1,000-4,000 \Omega \mathrm{m})$, which in turn begin to dissolve, and thus develop karst features. Water from the epikarstic zone slowly percolates into rock of limited permeability through joints and along bedding planes. Void spaces develop in areas where water passes, which raises the permeability and resistivity $(<4000 \Omega \mathrm{m})$ of the bedrock. If a void space becomes too 
large, it will collapse because it can no longer support the weight of the material above it.

The best way to understand the swale feature is to begin by evaluating the ER sections that are approximately perpendicular to the swale in order from the northeast to southwest (i.e., SW03, SW04, SW02, and SW01), then compare these with the ER sections that are approximately parallel to the swale (i.e. SW05 and SW07).

Both, SW03 and SW04 have an area of water saturated permeable rock, which are situated bellow and/or beside two small resistive $(<1000 \Omega \mathrm{m})$ features (Fig. 19, [SW03] and [SW04]). Below these near surface features may be a layer of limited permeability rock ( 500-1,000 $\Omega$ m) overlaying a high-resistivity $(<4,000$ $\Omega m)$ area that is possibly a void space. SW03 seems to show groundwater intruding into a concaved area, which may be a collapsed void space, from the north to northwestern section of the hill (Fig. 19, [SW03], horizontal 18.7 to $37.5 \mathrm{~m}$ ). This area has little to no surface water influence from the east and northeast.

Features in SW04 are generally horizontally oriented (Fig 19, [SW04]). It contains one area of saturated rock atop a single void space (Fig 19, [SW04], horizontal 18.7 to $43.7 \mathrm{~m}$ ). It is significantly thicker than the saturated area seen within SW03, which likely is the primary source of water to this location. This source is based on trend of plunge of the fold axis $\left(\sim 15^{\circ}\right)$, change in elevation, DEM stream model, and absence of a clear western source. The saturated rock appears to be causing the karstification of bedrock to its southeast towards the swale feature 
as seen by its encroachment between underlying permeable rock and a small blotch of permeable rock above (Fig. 19, [SW04], horizontal 37.5 to $49.9 \mathrm{~m}$ ). This may imply that groundwater from this point may not have a clear path to the northern apex of the swale feature. If the space beneath the area of water saturation in SW04 is in fact a void space, then it may eventually cave in and likely take a similar geometry as SW03; furthermore, it may cause the swale feature, as seen from the surface, to encroach further north.

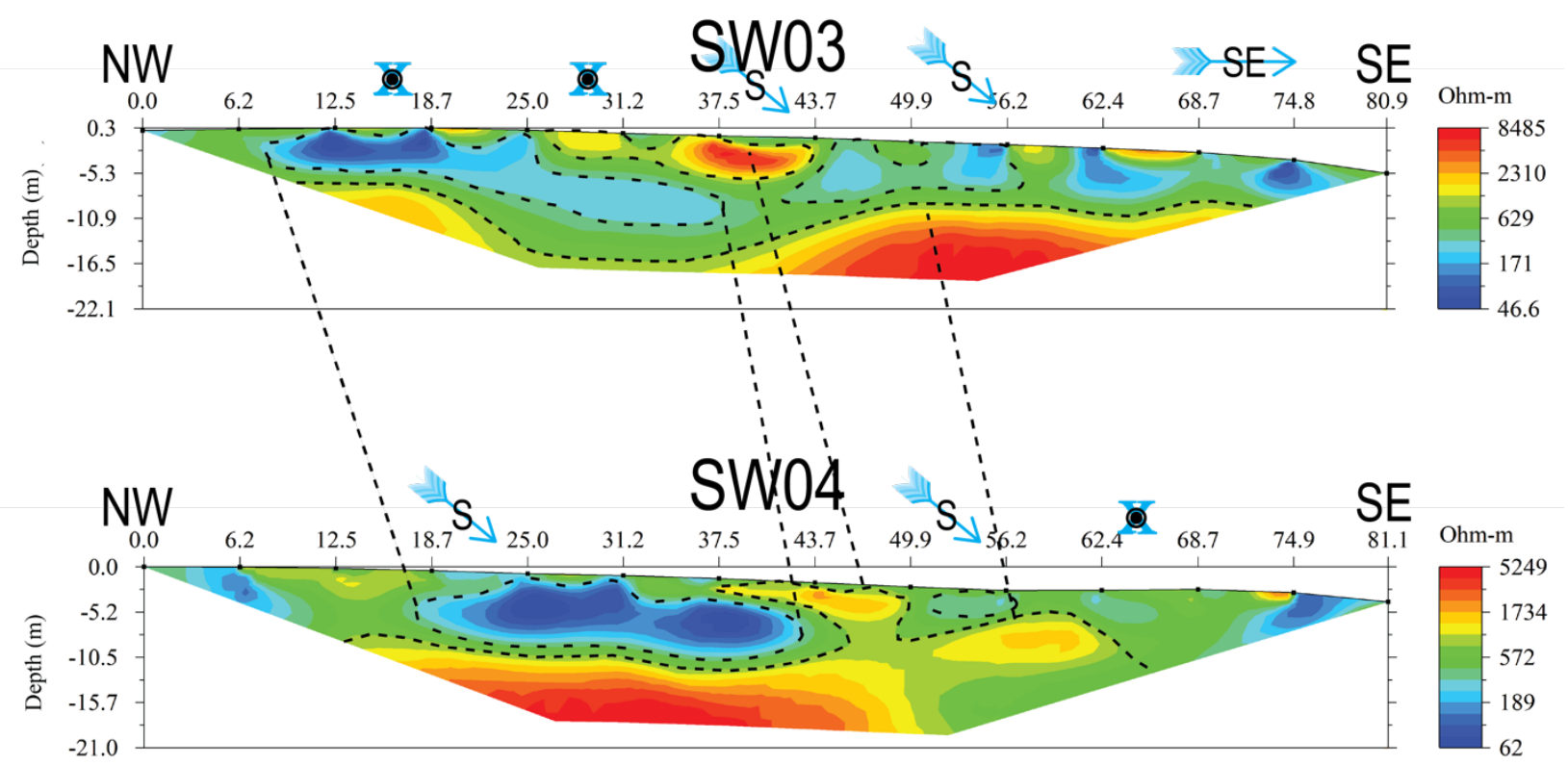

Figure 20. Correlated ER sections SW03 and SW04, location 1. Dashed-lines are drawn around significant and between corresponding features. Arrows signify direction in which surface water would flow as modeled by the streams (Fig. 17). For both sections, the horizontal distance between 43.7 and $56.2 \mathrm{~m}$ is approximately in line with the width of the swale.

SW02 is underlain by a layer of moderate-resistivity $(\sim 2,000 \Omega \mathrm{m})$ rock oriented concave down across the swale feature (Fig. 20, [SW02]). The depth of the ER section does not allow for the identification of any void spaces within the underlying concavity and it cannot be concluded, but it may be possible, that the concavity is due to a collapsed void space. The concave could be normal bedrock 
orientation because structure across the swale in this location is a high-order syncline. The ER section seems to show saturated ground protruding into the concave from the southeast and directly from the surface (Fig. 20, [SW02], horizontal $43 \mathrm{~m}$ ). There is area of saturation comparable in size to the one seen in SW04 on the western side of the swale (Fig, 20, [SW02], horizontal 12.4 to $31.1 \mathrm{~m}$ ). This saturation does not appear to protrude into the concave area beneath the swale.

SW02 also shows two high-resistivity $(\sim 2,000-7,582 \Omega \mathrm{m})$ circular-features situated near the surface on either side of the swale that were likely permeable rock with solutionally-enlarged joints, bedding planes, and/or fractures, the result of interaction with the saturated groundwater (Fig. 20, [SW02], horizontal $31.1 \mathrm{~m}$ and $49 \mathrm{~m}$ ). The feature on the northwestern side may be a cavity, and this could possibly allow for the percolation of groundwater to the surface. Further karstification may lead to future horizontal expansion of the swale and the opening of a clear path for this water to flow into the concave area. SW01 also shows a similar feature $(\sim 2000 \Omega \mathrm{m})$ on its northwestern side (Fig. 20, [SW01], horizontal 33 m). It is also possible that these may be connected as a conduit which extends between a four ER sections that are approximately perpendicular to the swale, which are the small ovoid resistive features connected with a dashed line (Fig. 19, [SW04] and [SW03]). 

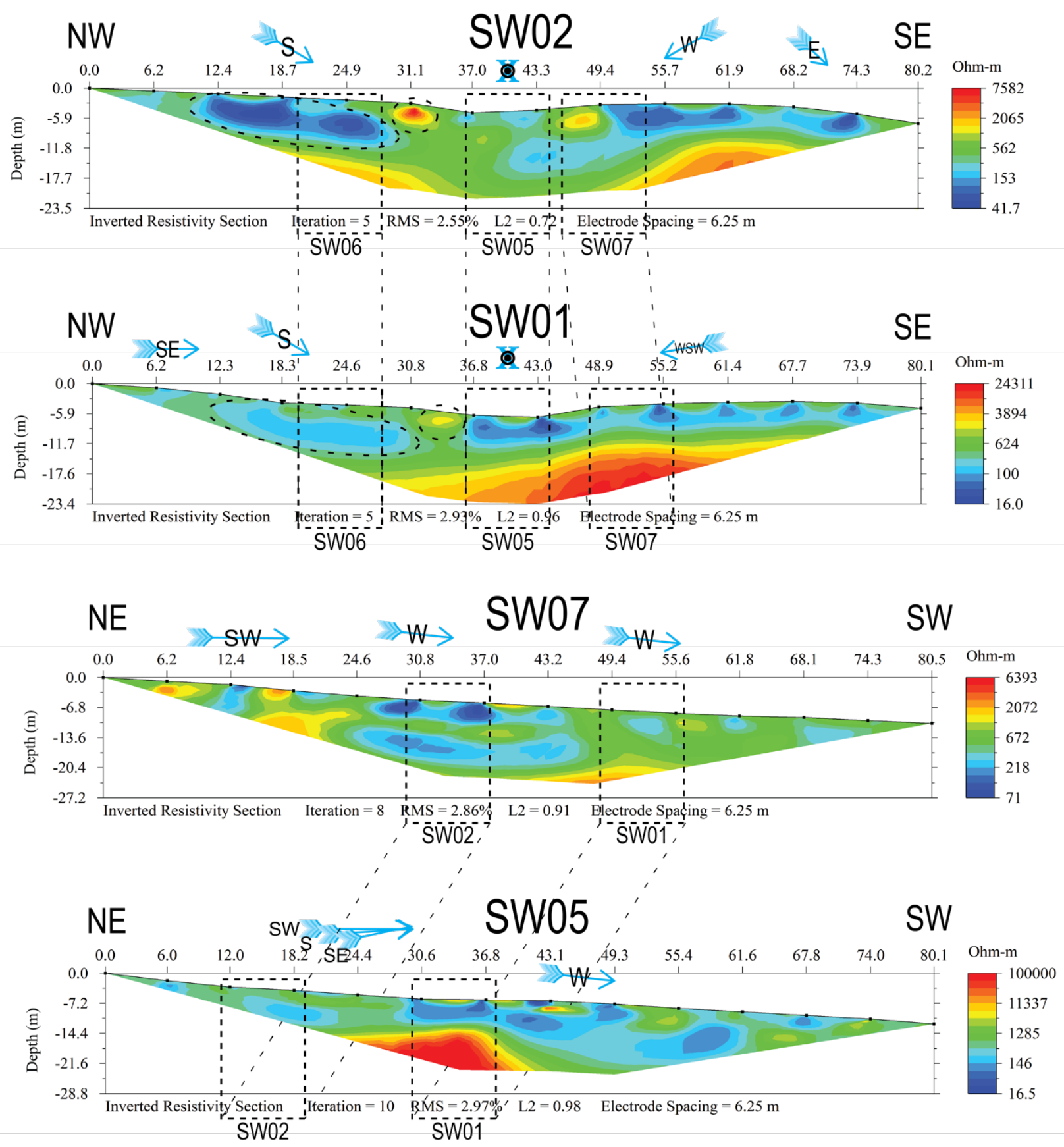

Figure 21. Correlated ER sections SW02, SW01, SW07, and SW05, location 1. Intersections with perpendicular lines are labeled and marked by dashed-boxes. Arrows signify direction in which surface water would flow as modeled by the streams (Fig. 17). SW05 is approximately parallel and centered within the swale feature between 0 and 40 meters, horizontal. SW07 runs approximately parallel to and along the upper rim/edge of the eastern flank of the swale. The swale feature is located between the horizontal distances 31.1 and $39.4 \mathrm{~m}$ for SW02 and SW01. SW07 does not pass through the swale, and SW05 is within the swale between 0 and $36.8 \mathrm{~m}$. 
Northwestern saturation is present in SW01, but still appears not to be sourcing water freely and directly beneath the feature (Fig. 20, [SW01], horizontal 12.3 to $30.8 \mathrm{~m}$ ); although, it does appear that some seepage is beginning to occur at this point. The western saturation has been traced through a ER sections that run approximately perpendicular to the swale (Fig. 19 [SW04] and [SW03]; Fig. 20. [SW02] and [SW01]); furthermore, it appears that access to the subsurface beneath the swale by western water is being blocked. SW06 is situated approximately parallel to the swale on its western flank (Fig. 17). The end of SW06 enters the swale just south of its intersection with SW01, which is also just after the swale deviates course westward (Fig. 17; Fig. 20, [SW01]). SW06 has a continuous band saturation across the section, which suggest that western sourced groundwater flows along the western flank of the swale and enters the subsurface beneath the swale after the swale deviates its course (Fig. 21).

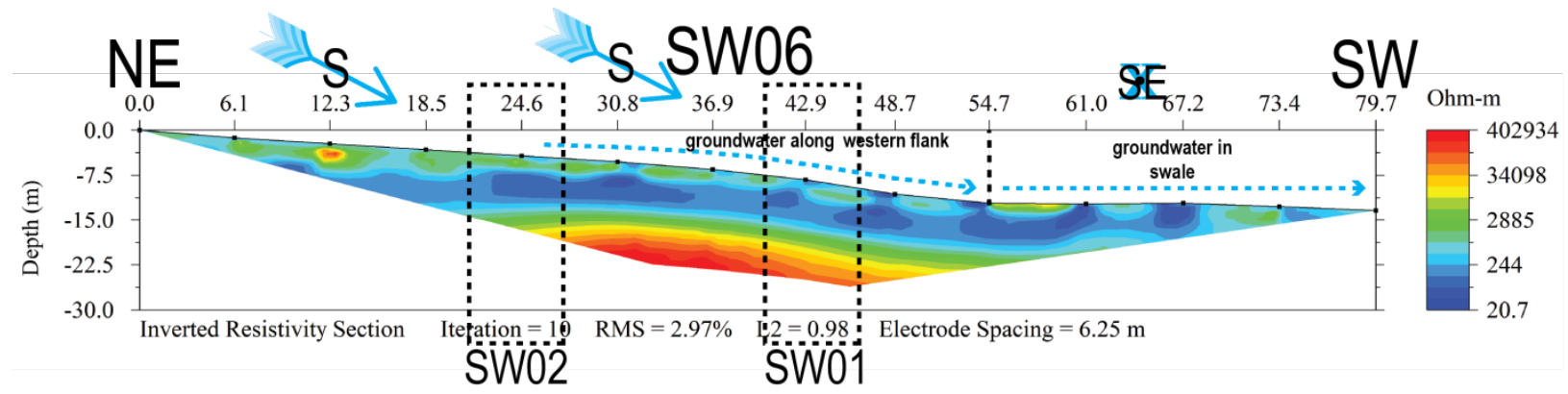

Figure 22. ER section SW06 has a continuous zone of saturation in the upper-subsurface, which, when correlated between SW03, SW04, SW02, and SW01 (Fig. 19; and Fig. 20), it can be assumed that western sourced ground water only enters the subsurface beneath the swale after the swale deviates its course westward (Fig. 17).

SW04 also has a high resistivity zone $\left(\sim 4 \cdot 10^{5} \Omega \mathrm{m}\right)$ at depth, which may be open-air void space (Fig. 21, horizontal 27 to $42.9 \mathrm{~m}$ ). SW04 also showed a void space underneath the western saturation (Fig. 29, [SW02], horizontal 18.7 to 43.7 
m), and SW03 may have a collapsed void beneath the western saturation (Fig. 29, [SW01], horizontal 18.7 to $37.5 \mathrm{~m}$ ). Since SW06 is roughly perpendicular to SW03 and SW04, and if the they all contain void space in which has been the result of heavy saturation, then the western flank of the swale could experience an entire collapse in the future.

A layer of saturation seen in SW01 extends from the southeast into the ground beneath and across the entire width of the ground beneath the swale feature (Fig. 20, [SW01]). There is void space underneath the southeastern side of the swale with a high resistivity value $(\sim 24,311 \Omega \mathrm{m})$ suggesting the possible presence of an open-air cave (Fig. 20, [SW01], horizontal 43 to $55 \mathrm{~m}$ ), and the same void space can be seen in SW05, which modeled a higher resistivity value $\left(<1 \cdot 10^{5}\right)$, at the intersection with SW01 (Fig. 20, [SW05]).

SW05 also indicates the presence of a large volume of saturated rock above the void (Fig. 20, [SW05], horizontal 30.6 to $61.6 \mathrm{~m}$ ). The source of the saturation can be traced between SW01, SW02, and SW07 (Fig. 20, [SW01, [SW02] and [SW07]). Also, the void space is located beside a location where the direction of the swale abruptly changes course (Fig. 20, [SW05], horizontal 35 to $40 \mathrm{~m}$ ). SW07 suggests that this void space may extend northeastward along the eastern flank of the swale; however, this is an assumption based off the location of saturation, which appears to have dissolved the bedrock into a canoe like shape ((Fig. 20, [SW07], horizontal 24.6 and $46 \mathrm{~m}$ ). The modeled streams indicate a moderate to high input of surface flow into the area south of SW02 due to the convergence of surface water 
from all northerly directions (Fig. 17). This suggests the area is highly susceptible to the erosional effects of both surficial water flow and groundwater saturation.

Figure 22 and 23 summarize how groundwater likely flows with respect to the four ER sections that are approximately perpendicular to the swale feature; note that water along the eastern flank either flows directly to the river or quickly into the swale feature. The northwestern sourced groundwater flows into the concave at SW03 (Fig. 22, [A]), then it is quickly routed to SW04 where its flow into the northern apex of the swale is blocked (Fig. 22, [B]). This area becomes super saturated and causes new karstification through slow seepage towards the swale feature and likely void space below. However, most western groundwater moves slowly from SW04 to SW02 based on the assumption that an area denser in conductive values (i.e., dark blue color values) suggests that the area remains highly saturated due to the inability to freely flow from the area (Fig. 22, [B] and $[\mathrm{C}])$.

At SW02, water flows in the swale from the northeast and into the swale from the east (Fig. 22, [C]; Fig. 23, [C]). Groundwater west of the swale begins to move more moderately towards SW01 (Fig. 22, [C] and [D]; Fig. 23 [C] and [D]). Then, it is rapidly emplaced beneath the swale feature, which has deviated its course slightly westward (Fig. 22, [D], Fig. 23, [D]). Due to the deviated course, north and eastern water is forced around a bend where it finally joins course with the eastern water. A significant void space is being formed beneath the bend on the 
eastern side of the swale (Fig. 23, [E]), which could cause further horizontal

expansion of the swales eastern flank.

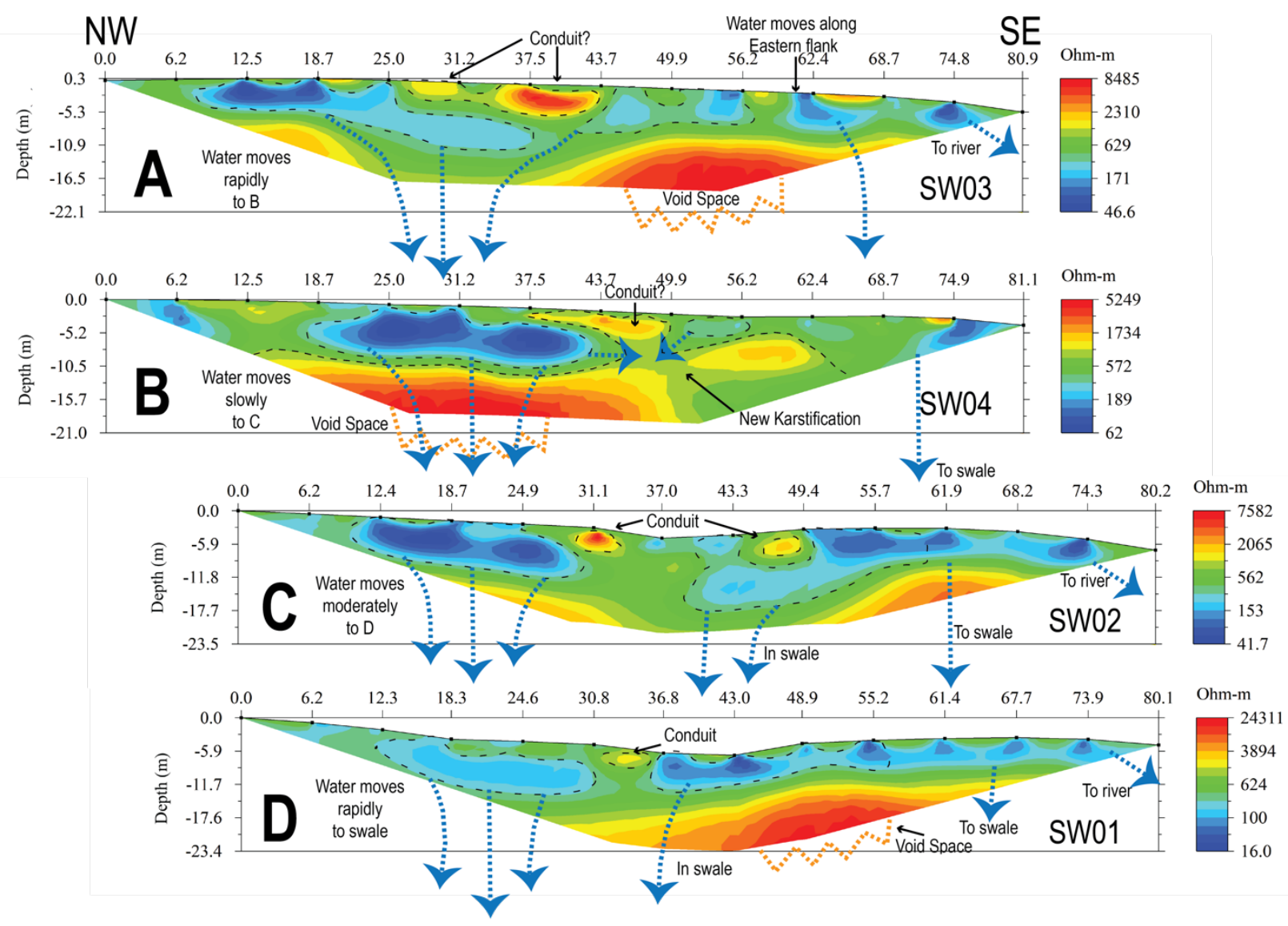

Figure 23. A-D are interpreted ER sections showing the water flow patterns through the swale feature. Northern and eastern groundwater can enter the swale near the northern apex.

Groundwater from the northwest is blocked from entering the swale's northern apex at B. It flows along the eastern bank to where the swale has undergone a deviation in its course. 


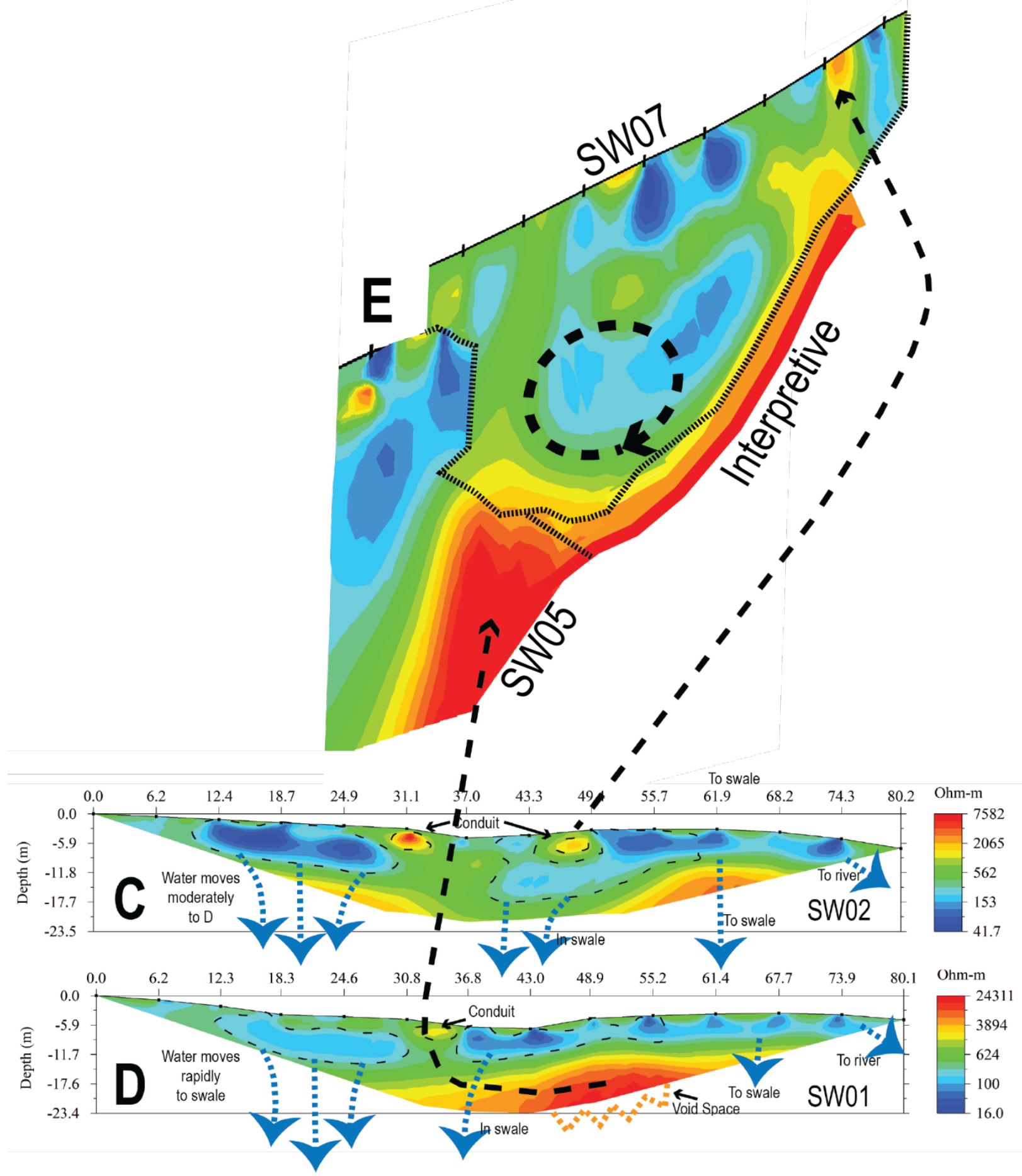

Figure 24. Interpretive mosaic of SW05 and SW07 [E] and their relative locations to SW01 [D] and SW02 [C]. Water from within the swale and water intruding from the east have formed a void beneath a bank where the swale deviates its course westward. SW07 may have a void space extending the length of its section, which has been interpreted in the mosaic. 


\subsection{Location 2, Caverns}

Figure 24 shows the ER section GCDD09 overlain on a TPI+hillshade image of location 2. Figure 25 shows the same for GCDD10, and will be referenced as supplement to GCDD09 as needed. The present location of known cave passages beneath the surface is overlain on the map in red (map provided by Daniel Doctor of the U.S. Geological Survey, 2016). The trend of the axial fold antiform is depicted by the yellow arrow and the cross-section profile A-A' location by a green line. Stars mark the location where strike and dip measurements were taken. Red dashed lines represent the western boundaries of the two confining layers, sandstone to west and dolostone to the east. Blue dashed lines are marked around sinkholes which that capture surface water, and blue arrows mark locations that do not impede the flow of water off the hill. The extent of the ER sections is marked by solid orange lines and electrode locations with points. Important areas of the ER sections (lettered A-J) are partitioned out with black-dashed lines between respective electrode locations on the maps and ER sections. Locations of certain features that correlate between GCDD09 and GCDD10 are circled by yellow dashed line.

The results indicate that two steeply dipping confining layers (Fig. $16 \mathrm{c}$; and Fig. 18) hinder the expulsion of surface and groundwater from the northwestern portion of Cave Hill. The 56-electrode ER section GCDD09 provided an image with depth penetration past the capillary fringe and into the water table approximately 61 to 73 meters below the surface (Fig. 24), which was confirmed by the elevation 
distance between the river and study location. It captured two portions of the cavern complex sitting between the water table ( $73 \mathrm{~m}$ depth) and below the epikarstic zone, which contains a network of perched aquifers ( $16 \mathrm{~m}$ depth) (Fig. 24). The aquifers found are situated under three sinkholes along the eastern side of a sandstone ridge which dips $\sim 70^{\circ} \mathrm{NW}$ (Fig. $24,[\mathrm{~A}],[\mathrm{B}]$, and [F]). Other aquifers are likely to exist beneath sinkholes along a second dolostone ridge approximately 50 meters to the east (Fig. 18; Fig. 24). These aquifers are likely providing water to the caverns below both through slow seepage and direct conduits.

Partition A bounds a large sinkhole at the surface ( 40 m diameter) (Fig. 24, [A]). A confining U-shaped layer ( $\sim 21 \mathrm{~m}$ depth) holds a perched aquifer beneath the sinkhole. On each side of the perched aquifer, two high-resistivity bodies $(<5,000$ $\Omega m)$ may be conduits that can feed water directly to the caverns below. A second smaller perched aquifer is nestled atop the caverns ( $16 \mathrm{~m}$ depth) aside boundary A/B (Fig. 24, [A] and [B]).

The Glossary of Geology defines endokarst as the entire area beneath the subsurface where dissolution has occurred and is ongoing (Neuendorf, Mehl, and Jackson, 2011). At partition B ( 16 to $50 \mathrm{~m})$, caverns cover the extent of the endokarst that lies bellow the epikarst (Fig. 24, [B]). Above the caverns is a Ushaped confining layer in the epikarst that likely holds a perched aquifer during wet periods. Currently, groundwater across this area flows into one of the perched aquifers within partition $\mathrm{A}$ and/or directly into the caverns below through a conduit seen on the B/C boundary (Fig. 24, [A], [B], and [C]). 
Partition C covers the central portion of the GCDD09 ER section (Fig. 24, $[\mathrm{C}]$ ), and the sinkhole within this portion, located at the intersection between GCDD01-06, GCDD09, and GCDD10, was the primary target for this study and the location of the USGS oxygen isotope and soil moisture study. This sinkhole sits above a currently dry perched aquifer in the epikarst and above and between two portions of the cavern complex in the endokarst bellow (Fig. 24, [B], [C], and [D]).

The aquifer beneath the primary sinkhole (Fig. 24, [C]) may be dry due to one, some, or all the following reasons. First, surface water has eroded and penetrated the sandstone ridge directly to the northwest, thus the ridge is no longer diverting any surface water towards the sinkhole (Fig. 18; Fig. 24, [C], [D], and [E], horizontal 167.5 to $242 \mathrm{~m}$ ). Second, the interpreted conduit beneath partition boundary C/D diverts surface water directly into the caverns (Fig. 24, [C] and [D], horizontal $186 \mathrm{~m}$ ). Third, the aquifer has been turned into a conduit itself through karstification, which has opened towards the caverns southeast of the sinkhole (Fig. 25, $[\mathrm{H}])$. The blue arrow stemming from the ER section marks the electrode of GCDD09 that is located above the section of caverns in which the conduit may lead. Depth markers within the partition correspond to the depth that caverns are seen in GCDD09. However, the geometry of GCDD10 insinuates that the conduit may lead to the southeast.

Both partitions D and E mark J-shaped perched aquifers which sit directly above the cavern system (Fig. 24, [D] and[E]). There is a small sinkhole along the calcareous arenite boundary at $\mathrm{D}$. The aquifer beneath likely feeds into the caverns 
directly through the conduit on the C/D boundary or by slow seepage. The location of this is also marked by a blue arrow beneath partition $\mathrm{H}$ (Fig. 25, $[\mathrm{H}])$ ). The perched aquifer at partition $\mathrm{E}$ does not appear to have direct conduit access, thus it likely feeds into the caverns by slow seepage.

Partition F extends over the calcareous arenite confining boundary and behind a fourth sinkhole (Fig. 24, [F]). A large mass of water is confined between the calcareous arenite and the caverns bellow. At the surface, strike and dip of this unit measured $215,69^{\circ} \mathrm{NW}$ and the location is marked by a green star on the $\mathrm{D} / \mathrm{E}$ boundary in figure 24, [D], [E]. However, the exact behavior of this unit in the subsurface was not captured in this ER section or in GCDD10. Referring to partition G (Fig. 25, [G]), we see the calcareous arenite abruptly disappears within the first 16 meters as it does in GCDD09 (Fig. 24, [F], horizontal 248 to $255 \mathrm{~m}$ ). Also, on the western side of the unit, there are two highly-resistive bodies $\left(<10 \cdot 10^{6}\right.$ $\Omega \mathrm{m}$ ), which are most likely open air caves (Fig. 24, [F], horizontal 248 to $298 \mathrm{~m}$ ). The aquifer sourced from the sinkhole on the eastern side of the ridge appears to extend beneath the calcareous arenite to the area between the two caves (Fig. 24, [F], horizontal 248 to $280 \mathrm{~m}$ ). The extent and behavior of this calcareous arenite boundary should be subject of another investigation. 


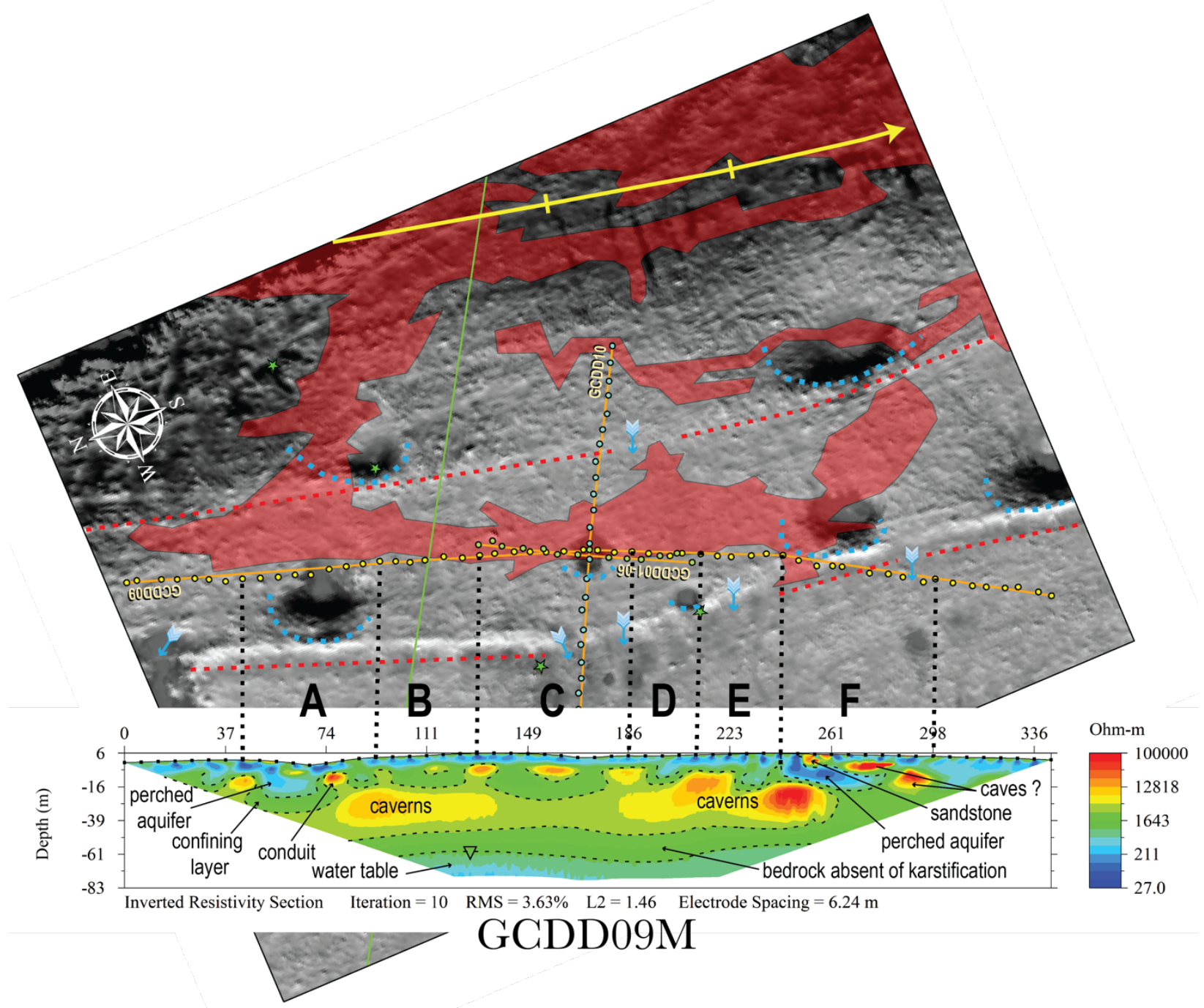

Figure 25. Interpreted ER section GCDD09 and hillshade + TPi image of the location two study area. Known cave passages are overlaid in red. The 56-electrode array captured an image to water table beneath Cave Hill $(\sim 61 \mathrm{~m})$. Two large sections of caverns sit underneath perched aquifers that are recharged through the sinkholes at the surface. The aquifers likely provide water to the caverns both through slow seepage and directly by conduits. The ER section is partitioned out with letters A$\mathrm{F}$ by correlation between the map, epikarstic and endokarstic layers. Background image is a hillshade + topographic position index map provided by Daniel Doctor of the U.S. Geological Survey (adapted from USGS, 2016, unpublished LiDAR [image/data]). Known cave passages overlay courtesy of Daniel Doctor of the U.S. Geological Survey. 


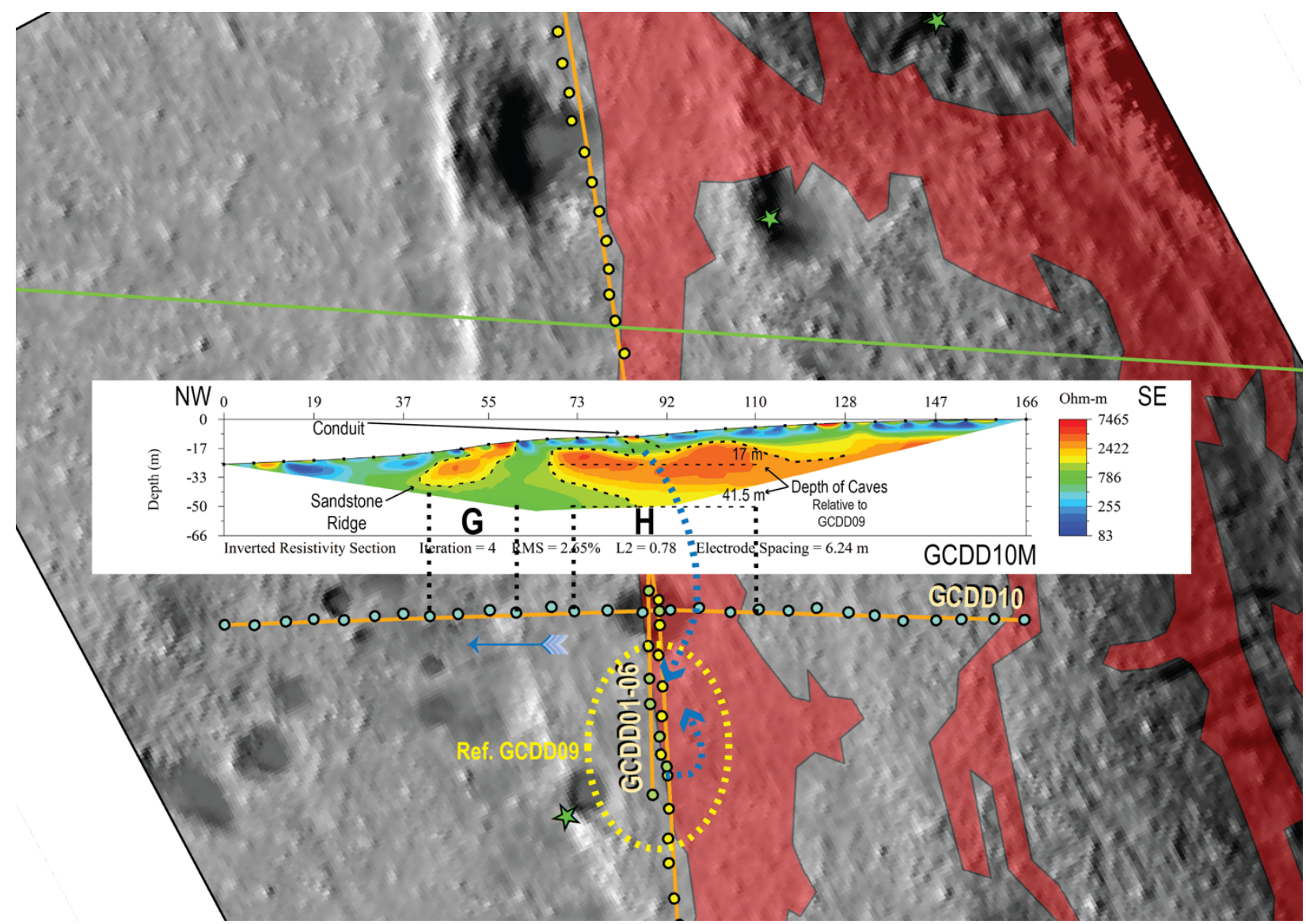

Figure 26. Interpreted ER section GCDD10 and hillshade + TPi image of the location two study area. Known cave passages are overlaid in red. The depth of the Caverns captured by GCDD09 are relative to the surface. Important correlations to GCDD09 are circled in yellow and marked with blue-dashed arrows. Partition G marks the confining sandstone layer, which disappears in both ER sections. Partition $\mathrm{H}$ marks the area beneath the central study location, which may contain a conduit to the Caverns. Background image is a hillshade + topographic position index map provided by Daniel Doctor of the U.S. Geological Survey (adapted from USGS, 2016, unpublished LiDAR [image/data]). Known cave passages overlay courtesy of Daniel Doctor of the U.S. Geological Survey.

\subsection{Conclusions}

The structural investigation indicates that the southern portion of Cave Hill generally consists of shallowly to moderately dipped algal laminated dolostone beds $\left(\sim 45^{\circ}\right)$ (Fig. 16 a and b). The swale feature generally follows the trend of an antiform ( $\sim 216^{\circ} \mathrm{SSW}$, w.r.t. true North) at approximately the same angle as the plunge of the axial fold $\left(\sim 15^{\circ}\right)$. One thin bed $(\sim 2 \mathrm{~m})$ of mic-sparite was observed that exists beneath the swale feature at a depth shallow enough to affect the features geometry 
if a void space within that bed were to form and collapse; although not observed in the field, there are likely other thin beds of sparite/micrite in the upper-subsurface beneath the swale. This along with the indication that most surface water can escape relatively freely from the southern portion of Cave Hill (Fig. 17), suggests that large caverns and/or caves are not likely present in the southern portion of Cave Hill; furthermore, the open-air/ highly permeable void spaces that do develop likely consist of long narrow conduit-like passages, which when collapsed, would resemble the long and narrow linear pattern of the swale feature seen at the surface.

The structural investigation indicates that the northern portion of Cave Hill generally consists of sub vertically dipped $\left(<70^{\circ}\right)$ bedding in which algal laminated micrite beds are confined between calcareous arenite and/or dolostone (Fig. 16 c). The calcareous arenite and dolostone beds does not undergo dissolution as readily as the micrite dominated rock, and they form two ridges, along the northwestern flank of Cave Hill; calcareous arenite to the west and dolomite to the east (Fig. 18; and Fig. 24).

The plunge of the antiform axial fold in the northern section $\left(\sim 20^{\circ} \mathrm{SSW}\right)$ is steeper than the one estimated for the southern section, but surface water generally flows northwest in the direction of the steeply dipped beds (Fig. 18). The ridges act as a barrier to the flow of surface water of the northwestern side of Cave Hill, and the water is quickly absorbed into the ground beneath sinkholes, which have formed along the eastern side of the ridges. The dissolution that is the result of this process 
has allowed for the formation the enormous cavern complex we see today, Groundwater east of the ridges either finds its way through the ridges, into perched aquifers where it slowly seeps into the caverns bellow, or is carried directly to the caverns through a conduit.

This research has uncovered and verified a few things about Cave Hill; however, it has raised more questions than it has answered. The overall geometry of void spaces beneath the swale feature and the full distribution of perched aquifers and void spaces against the ridges were not revealed. Then, there is a question about the area of Cave Hill that transitions between the two bedding geometry types.

Strike measurements of the middle section of Cave Hill do not follow the same SSW-NNE trend as the sections to the north and south (Fig. 26, [A]). This could be due to measurements being taken close to a fold axis where there is relatively shallow dip, which may not give valid strike and dip measurements. However, one set of measurements recorded approximately west-east strike and dip of $43^{\circ}$ south, which should be sufficient dip to record a valid strike measurement (Fig. 26, [A]). Cave Hill appears to be S-shaped when viewing it from an aerial perspective (Fig. 26). This may suggest that the abrupt change in bedding geometry from the southern to northern section of Cave Hill is due to bending in the fold axes or the possible existence of a fault, but this cannot be confirmed from the image due to the inability to accurately trace the northern and southern ridges into the middle section. 
The ridge along the southeastern flank is generally consistent with trend of plunge ( 214 $\left.{ }^{\circ} \mathrm{SSE}\right)$ (Fig. 26, [B] to [C]). In the middle portion of Cave Hill, the ridge along the southeastern flank appears that it could deviate westward (Fig. 26, [C] to [D]). The northeastern flank follows the estimated trend of the fold axis for only a short distance before also appearing to deviate eastward to the south, but this deviation seems less sudden than what was is seen with the southeastern flank (Fig. 26, [D] to [E]). The western most flank can be traced through the middle section, and has a slight eastward deviation (Fig. 26, [F] to [G]); however, it does not completely mimic the hypothetical S-shape deviation pattern. The western most flank also shows a clear westward deviation to the north (Fig, 26, [F] to [G']).

An extensive resistivity survey conducted on the middle portion of the hill may help to verify or refute the existence of a fault and/or extensive bending of fold axes. Figure 27 shows several possible combinations of overlapping ER quad-lines that could be applied to future studies on Cave Hill. Completing these lines would help to answer the questions that pertain the southern and northern sections separately, and the unclear transition between the two portions of the hill. 


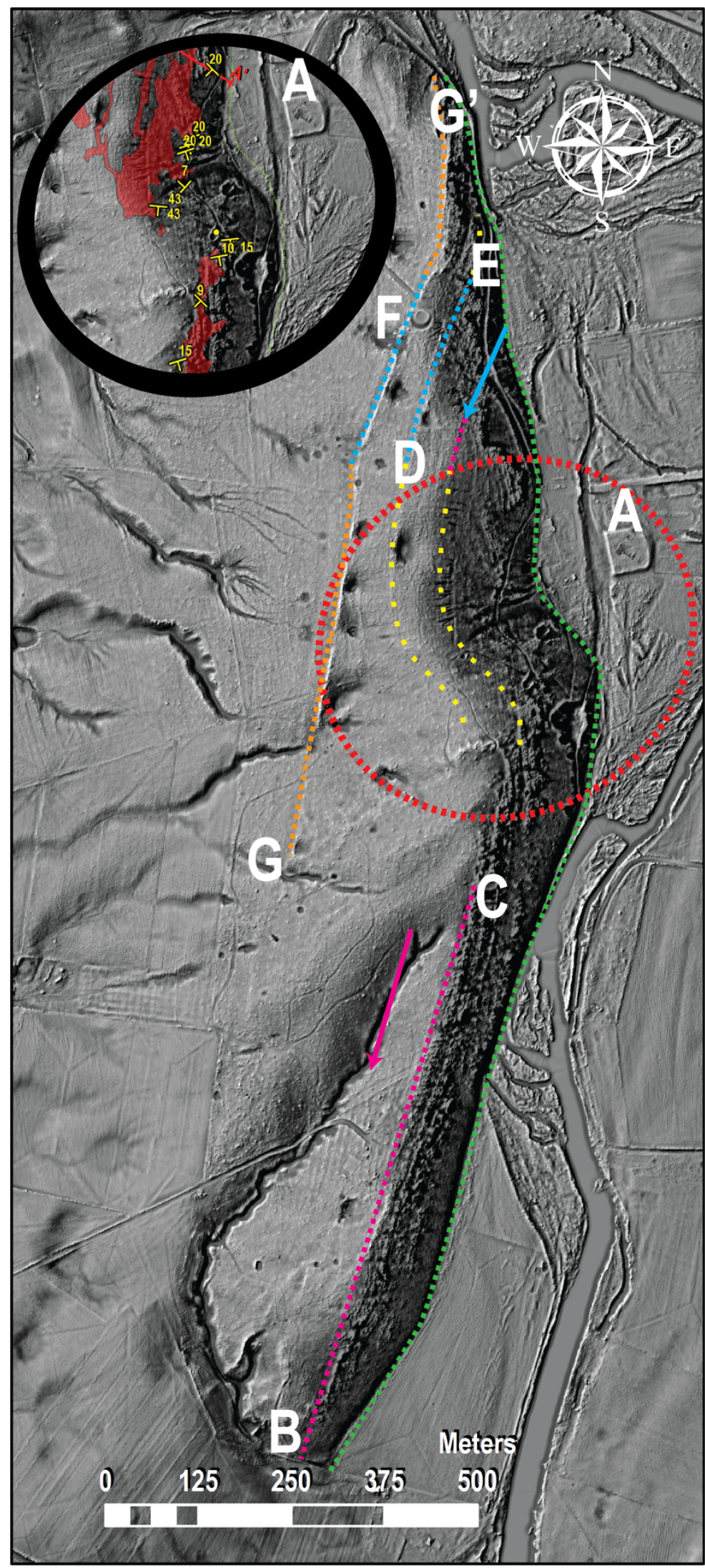

Figure 27. Interpretive fold axis trend of Cave Hill using strike and dip measurements and hillshade + TPI image. The measurements and image suggest the fold axes may be bent or faulted in the middle portion of the hill. [A] circled in red and projected out of the main image marks the location of southern dipped beds, strike is symbolized and dip is numerically expressed in the projected image in yellow, and known cave passages are overlaid in the projected image in red. Solid arrowed lines are estimated fold axes shortened to match the trend visible by the hillshade image, southern fold axis in magenta and northern in blue. Portions of ridges which mimic or deviate from the trend of one of the estimated fold axes are marked by dashed lines. Dashed lines corresponding in color to a fold axis are placed on ridges which approximately follow the same trend as the fold axis. Yellow dashed lines are placed on ridges that have a questionable deviation in trend from a fold axis. Orange dashed lines are placed on ridges that do show deviation in trend from a fold axis. A green dashed line marks the eastern boundary of Cave Hill. Background image is a hillshade + topographic position index map provided by Daniel Doctor of the U.S. Geological Survey (adapted from USGS, 2016, unpublished LiDAR [image/data]). Known cave passages overlay courtesy of Daniel Doctor of the U.S. Geological Survey. 
EM was anticipated to be used to further investigate perched aquifers identified by the ER sections; however, this was unable to be completed. EM was deployed at two different locations above suspected perched aquifers revealed by ER section GCDD09, but the electrode locations in the ER section used were later determined to be reversed. One of the EM deployments ultimately was not situated over a perched aquifer. The other EM deployment was conducted in the primary sinkhole of interest where the center electrode of GCDD09 was located. There was no groundwater present above the confining layer at the time of the ER deployment, but the confining layer had a similar geometry to the others which contain perched aquifers. An evaluation of the EM data may give better insight to this confining layer. Figure 28 highlights the locations where these two EM deployments were conducted as well as potential future deployments above perched aquifers identified in ER section GCDD09. 


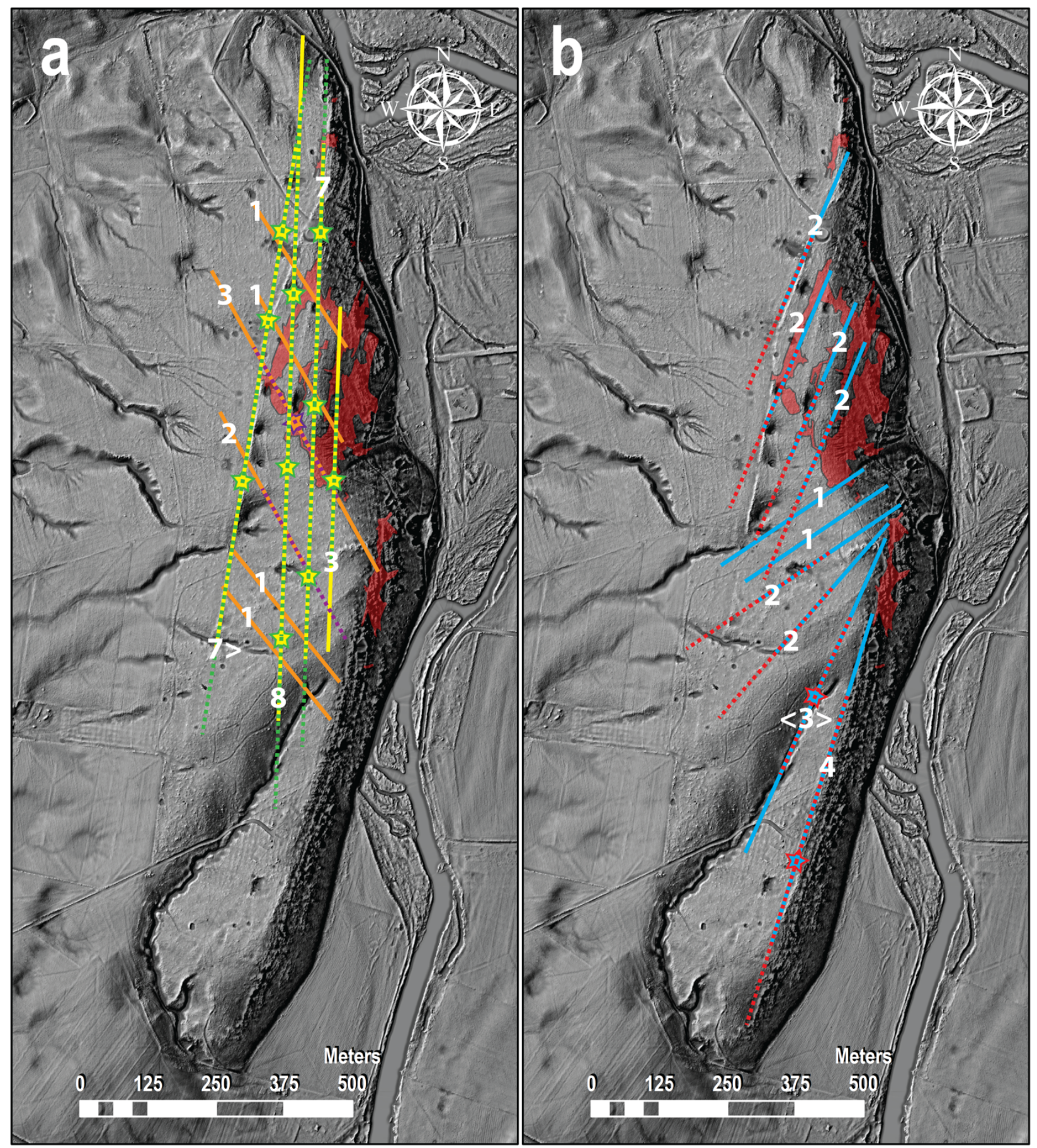

Figure 28. Possible combinations of overlapping ER quad-lines on Cave hill. The amount of ER lines per transect are displayed, and angular brackets, $\langle>$, suggest that the same number of parallel lines could be deployed adjacent and to the one depicted and in the direction of the brackets apex. stars mark two end to end lines with a third centered between. a. possible combinations of northsouth quad-lines in green and yellow and northwest-southeast quad-lines in orange, 41 lines total. b. possible combinations of southwest-northeast quad-lines in blue and red, 27 lines total. Background image is a hillshade + topographic position index map provided by Daniel Doctor of the U.S. Geological Survey (adapted from USGS, 2016, unpublished LiDAR [image/data]). Known cave passages overlay courtesy of Daniel Doctor of the U.S. Geological Survey. 


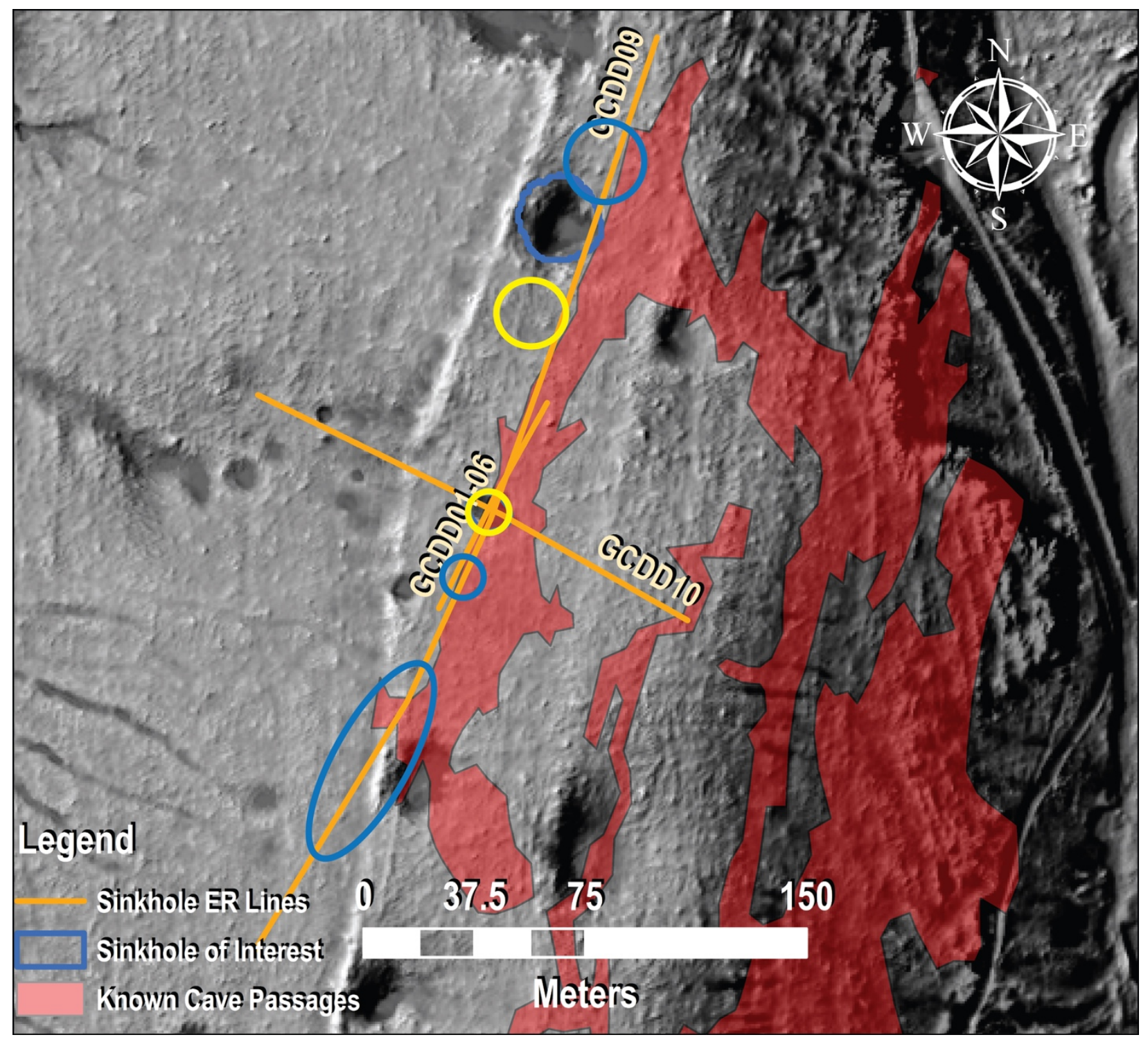

Figure 29. Conducted and future EM deployment locations based on perched aquifers identified by ER section GCDD09. Conducted deployments highlighted in yellow and potential future deployments in blue. Background image is a hillshade + topographic position index map provided by Daniel Doctor of the U.S. Geological Survey (adapted from USGS, 2016, unpublished LiDAR [image/data]). Known cave passages overlay courtesy of Daniel Doctor of the U.S. Geological Survey. 


\section{Appendix A}

\begin{tabular}{|c|c|c|c|c|}
\hline \multicolumn{5}{|c|}{$\begin{array}{l}\text { Table of Stratigraphic Formation Symbols } \\
\text { for the Shenandoah Valley, Virginia }\end{array}$} \\
\hline Symbol $^{1}$ & Stratigraphic Formation & Period & Rock Type 1 & Rock Type 2 \\
\hline Dsoz & $\begin{array}{l}\text { Lower Devonian, Silurian and } \\
\text { Upper Ordovician Formations } \\
\text { Undivided }\end{array}$ & $\begin{array}{l}\text { Ordovician- } \\
\text { Devonian }\end{array}$ & sandstone & shale \\
\hline $\mathrm{DSu}$ & $\begin{array}{l}\text { Ridgeley Sandstone, } \\
\text { Helderberg and Cayugan } \\
\text { Groups }\end{array}$ & $\begin{array}{l}\text { Silurian- } \\
\text { Devonian }\end{array}$ & limestone & sandstone \\
\hline $\mathrm{DSz}$ & $\begin{array}{l}\text { Lower Devonian and Silurian } \\
\text { Formations Undivided }\end{array}$ & $\begin{array}{l}\text { Silurian- } \\
\text { Devonian }\end{array}$ & sandstone & limestone \\
\hline $\mathrm{Db}$ & Brallier Formation & Devonian & shale & siltstone \\
\hline Dch & Chemung Formation & Devonian & shale & sandstone \\
\hline Dhs & Hampshire Formation & Devonian & sandstone & limestone \\
\hline Dma & Mahantango Formation & Devonian & sandstone & siltstone \\
\hline Dmn & $\begin{array}{l}\text { Millboro Shale and Needmore } \\
\text { Formation }\end{array}$ & Devonian & black shale & shale \\
\hline Dmrn & $\begin{array}{l}\text { Marcellus Shale and } \\
\text { Needmore Formation }\end{array}$ & Devonian & black shale & shale \\
\hline Mpo & Pocono Formation & Mississippian & sandstone & shale \\
\hline $\mathrm{O}[\mathrm{co}$ & Conococheague Formation & $\begin{array}{l}\text { Cambrian- } \\
\text { Ordovician }\end{array}$ & limestone & $\begin{array}{l}\text { dolostone } \\
\text { (dolomite) }\end{array}$ \\
\hline $\mathrm{Ob}$ & Beekmantown Group & Ordovician & $\begin{array}{l}\text { dolostone } \\
\text { (dolomite) }\end{array}$ & limestone \\
\hline Oeln & $\begin{array}{l}\text { Edinburg Formation, } \\
\text { Lincolnshire and New Market } \\
\text { Limestones }\end{array}$ & Ordovician & limestone & black shale \\
\hline $\mathrm{Om}$ & $\begin{array}{l}\text { Martinsburg and Oranda } \\
\text { Formations }\end{array}$ & Ordovician & shale & sandstone \\
\hline Oun & $\begin{array}{l}\text { Juniata, Oswego, } \\
\text { Martinsburg (Reedsville and } \\
\text { Dolly Ridge), and Eggleston } \\
\text { Formations }\end{array}$ & Ordovician & shale & mudstone \\
\hline $\mathrm{Oz}$ & $\begin{array}{l}\text { Upper and Middle Ordovician } \\
\text { Formations Undivided }\end{array}$ & Ordovician & shale & sandstone \\
\hline $\mathrm{SOz}$ & $\begin{array}{l}\text { Silurian and Upper } \\
\text { Ordovician Formations } \\
\text { Undivided }\end{array}$ & $\begin{array}{l}\text { Ordovician- } \\
\text { Silurian }\end{array}$ & sandstone & shale \\
\hline Skrt & $\begin{array}{l}\text { Keefer, Rose Hill, and } \\
\text { Tuscarora Formations }\end{array}$ & Silurian & arenite & shale \\
\hline $\mathrm{Sm}$ & Massanutten Sandstone & Silurian & arenite & quartzite \\
\hline Yal & Alkali Feldspar Leucogranite & Proterozoic Y & granite & \\
\hline Yc & Charnockite & Proterozoic Y & granitic & \\
\hline
\end{tabular}

\footnotetext{
1 The open bracket ( [ ) stands for the Cambrian symbol ( $\subset$ ).
} 


\begin{tabular}{|l|l|l|l|l|}
\hline & & & gneiss & \\
\hline Ygn & $\begin{array}{l}\text { Leucocratic Granulite and } \\
\text { Gneiss }\end{array}$ & Proterozoic Y & granulite & gneiss \\
\hline Yhg & Megacrystic Charnockite & Proterozoic Y & granite & \\
\hline Y] & Leucocharnockite & Proterozoic Y & granite & \\
\hline Ypg & Layered Pyroxene Granulite & Proterozoic Y & granulite & \\
\hline Zsr & Swift Run Formation & Proterozoic Z & phyllite & sandstone \\
\hline$[$ Zc & Catoctin Formation & $\begin{array}{l}\text { Proterozoic Z - } \\
\text { Cambrian }\end{array}$ & meta-basalt & \\
\hline$[\mathrm{ch}$ & Chilhowee Group & Cambrian & quartzite & conglomerate \\
\hline$[\mathrm{e}$ & Elbrook Formation & Cambrian & $\begin{array}{l}\text { dolostone } \\
\text { (dolomite) }\end{array}$ & limestone \\
\hline$[\mathrm{r}$ & Rome Formation & Cambrian & shale & siltstone \\
\hline$[\mathrm{s}$ & Shady Dolomite & $\begin{array}{l}\text { dolostone } \\
\text { (dolomite) }\end{array}$ & limestone \\
\hline$[\mathrm{wb}$ & Waynesboro Formation & Cambrian & $\begin{array}{l}\text { dolostone } \\
\text { (dolomite) }\end{array}$ & shale \\
\hline$[\mathrm{wbt}$ & $\begin{array}{l}\text { Waynesboro Formation and } \\
\text { Tomstown Dolomite }\end{array}$ & Cambrian & $\begin{array}{l}\text { dolostone } \\
\text { (dolomite) }\end{array}$ & Shale \\
\hline basalt & $\begin{array}{l}\text { Valley and Ridge Igneous } \\
\text { Intrusions; Basalt }\end{array}$ & $\begin{array}{l}\text { Jurassic- } \\
\text { Tertiary }\end{array}$ & $\begin{array}{l}\text { basalt } \\
\text { andesite }\end{array}$ \\
\hline
\end{tabular}




\section{Appendix B}

\begin{tabular}{|l|l|l|l|l|l|l|l|}
\hline \multicolumn{7}{|c|}{ SW03 Electrode Points Interpolation Table } \\
\hline $\begin{array}{c}\text { Elect- } \\
\text { rode }\end{array}$ & $\begin{array}{c}\text { Accu- } \\
\text { racy } \\
\text { (m) }\end{array}$ & $\begin{array}{c}\text { Measured X } \\
\text { (WGS) }\end{array}$ & $\begin{array}{c}\text { Measured Y } \\
\text { (WGS) }\end{array}$ & $\begin{array}{c}\text { Measured Z } \\
\text { (m) }\end{array}$ & $\begin{array}{c}\text { Interpolated X } \\
\text { (WGS) }\end{array}$ & $\begin{array}{c}\text { Interpolated Y } \\
\text { (WGS) }\end{array}$ & DEM Z (m) \\
\hline 1 & 4.069 & -78.83604346 & 38.253727 & 438.2988072 & -78.83677248 & 38.25420107 & 415.6294861 \\
\hline 2 & 4.907 & -78.83604566 & 38.25374739 & 433.9782526 & -78.83671673 & 38.25416628 & 415.8006897 \\
\hline 3 & 5.18 & -78.83610137 & 38.25382432 & 425.4229634 & -78.83666085 & 38.25413139 & 415.9284668 \\
\hline 4 & 3.875 & -78.83615505 & 38.25382479 & 426.0976457 & -78.83660482 & 38.25409642 & 415.9408569 \\
\hline 5 & 4.86 & -78.83621196 & 38.25386461 & 423.9124034 & -78.8365487 & 38.25406139 & 415.680481 \\
\hline 6 & 4.725 & -78.83630458 & 38.25390671 & 439.6710157 & -78.83649258 & 38.25402636 & 415.2668762 \\
\hline 7 & 4.025 & -78.83632086 & 38.25393154 & 425.8032335 & -78.83643691 & 38.25399161 & 414.9538269 \\
\hline 8 & 4.685 & -78.83636871 & 38.25398093 & 417.2178414 & -78.83638113 & 38.25395679 & 414.7227478 \\
\hline 9 & 4.475 & -78.83643728 & 38.25402319 & 419.6051695 & -78.8363252 & 38.25392188 & 414.2515564 \\
\hline 10 & 4.997 & -78.83647475 & 38.25400177 & 425.3191617 & -78.83626938 & 38.25388704 & 413.8841553 \\
\hline 11 & 4.781 & -78.83655426 & 38.25401167 & 440.0737472 & -78.83621356 & 38.2538522 & 413.445221 \\
\hline 12 & 4.231 & -78.83661833 & 38.25412036 & 432.874719 & -78.83615721 & 38.25381702 & 412.9315796 \\
\hline 13 & 4.824 & -78.83668076 & 38.25415053 & 419.3555357 & -78.83610143 & 38.2537822 & 412.0229187 \\
\hline 14 & 4.73 & -78.83673606 & 38.25417614 & 420.0548656 & -78.83604566 & 38.25374739 & 410.3747864 \\
\hline
\end{tabular}

\begin{tabular}{|l|l|l|l|l|l|l|l|}
\hline \multicolumn{7}{|c|}{ SW04 Electrode Points Interpolation Table } \\
\hline $\begin{array}{c}\text { Elect- } \\
\text { rode }\end{array}$ & $\begin{array}{c}\text { Accu- } \\
\text { racy } \\
\text { (m) }\end{array}$ & $\begin{array}{c}\text { Measured X } \\
\text { (WGS) }\end{array}$ & $\begin{array}{c}\text { Measured Y } \\
\text { (WGS) }\end{array}$ & $\begin{array}{c}\text { Measured Z } \\
(\mathbf{m})\end{array}$ & $\begin{array}{c}\text { Interpolated X } \\
\text { (WGS) }\end{array}$ & $\begin{array}{c}\text { Interpolated Y } \\
\text { (WGS) }\end{array}$ & DEM Z (m) \\
\hline 1 & 2.975 & -78.83691045 & 38.25406197 & 411.3275984 & -78.83691045 & 38.25406197 & 414.0082398 \\
\hline 2 & 3.694 & -78.83684237 & 38.2540039 & 420.7666914 & -78.8368456 & 38.25403112 & 413.9821777 \\
\hline 3 & 3.001 & -78.83672271 & 38.25394803 & 427.0716258 & -78.83678459 & 38.2540021 & 413.8293457 \\
\hline 4 & 2.92 & -78.8366737 & 38.25395921 & 421.1152018 & -78.83672387 & 38.25397322 & 413.5713806 \\
\hline 5 & 3.746 & -78.83662731 & 38.25393962 & 412.3471354 & -78.83666266 & 38.2539441 & 413.2163696 \\
\hline 6 & 3.377 & -78.83657038 & 38.25386617 & 413.3663647 & -78.83660286 & 38.25391565 & 413.009552 \\
\hline 7 & 3.173 & -78.83650769 & 38.25388071 & 416.7659977 & -78.83654179 & 38.25388661 & 412.661377 \\
\hline 8 & 4.096 & -78.83642389 & 38.25388894 & 401.6927499 & -78.83648107 & 38.25385773 & 412.1903992 \\
\hline 9 & 3.24 & -78.83642797 & 38.25385651 & 413.8917273 & -78.83641997 & 38.25382866 & 411.6951599 \\
\hline 10 & 2.889 & -78.8364014 & 38.25368433 & 456.8800309 & -78.83635884 & 38.25379959 & 411.2733154 \\
\hline 11 & 8.615 & -78.83628896 & 38.25375174 & 411.3124591 & -78.83629785 & 38.25377057 & 411.2946167 \\
\hline 12 & 4.029 & -78.83620608 & 38.25374326 & 418.2679933 & -78.83623644 & 38.25374136 & 411.4075623 \\
\hline 13 & 3.239 & -78.83615515 & 38.25371247 & 412.8139499 & -78.83617618 & 38.2537127 & 411.0333862 \\
\hline 14 & 3.148 & -78.8360887 & 38.25365652 & 418.702307 & -78.83611566 & 38.25368375 & 409.9656677 \\
\hline
\end{tabular}

\begin{tabular}{|l|l|l|l|l|l|l|l|}
\hline \multicolumn{7}{|c|}{ SW05 Electrode Points Interpolation Table } \\
\hline $\begin{array}{c}\text { Elect- } \\
\text { rode }\end{array}$ & $\begin{array}{c}\text { Accu- } \\
\text { racy } \\
(\mathbf{m})\end{array}$ & $\begin{array}{c}\text { Measured X } \\
\text { (WGS) }\end{array}$ & $\begin{array}{c}\text { Measured Y } \\
\text { (WGS) }\end{array}$ & $\begin{array}{c}\text { Measured Z } \\
(\mathbf{m})\end{array}$ & \multicolumn{2}{|c|}{$\begin{array}{c}\text { Interpolated X } \\
\text { (WGS) }\end{array}$} & \multicolumn{2}{c|}{$\begin{array}{c}\text { Interpolated Y } \\
\text { (WGS) }\end{array}$} & DEM Z (m) \\
\hline 1 & 4.5 & -78.83684715 & 38.25328367 & 412.5666669 & -78.83689369 & 38.25318087 & 398.3211975 \\
\hline 2 & 4.054 & -78.83680432 & 38.25330198 & 406.161682 & -78.83685087 & 38.253223 & 399.4664917 \\
\hline 3 & 3.936 & -78.83675896 & 38.25337356 & 400.166253 & -78.83680897 & 38.25326448 & 400.2505493 \\
\hline 4 & 4.276 & -78.83670095 & 38.25340726 & 414.5240745 & -78.83676458 & 38.25330837 & 401.1347351 \\
\hline 5 & 3.748 & -78.83666685 & 38.25344206 & 411.029452 & -78.83671418 & 38.25335131 & 401.9290161 \\
\hline 6 & 3.723 & -78.83663332 & 38.25348779 & 406.8665338 & -78.83666976 & 38.25339638 & 402.9770813 \\
\hline 7 & 4.72 & -78.83659239 & 38.25350513 & 419.252434 & -78.83662474 & 38.25343608 & 403.7044983 \\
\hline 8 & 3.678 & -78.83652084 & 38.25355802 & 409.9930529 & -78.83658035 & 38.25347997 & 403.8985291 \\
\hline
\end{tabular}




\begin{tabular}{|l|l|l|l|l|l|l|l|}
\hline 9 & 3.634 & -78.83648735 & 38.25361001 & 412.4256155 & -78.83654046 & 38.25352513 & 404.1115418 \\
\hline 10 & 3.68 & -78.83646522 & 38.25366093 & 412.4318306 & -78.83650282 & 38.25357092 & 405.132782 \\
\hline 11 & 3.664 & -78.83637649 & 38.25367543 & 409.0657907 & -78.83646667 & 38.25361735 & 406.2034302 \\
\hline 12 & 3.61 & -78.83635147 & 38.25374275 & 417.2329412 & -78.83643432 & 38.25366324 & 406.9664307 \\
\hline 13 & 3.728 & -78.83633771 & 38.25380615 & 417.3594271 & -78.83639886 & 38.25371206 & 408.4790039 \\
\hline 14 & 3.704 & -78.83628634 & 38.25384071 & 417.5472642 & -78.83636341 & 38.25376028 & 410.2723694 \\
\hline
\end{tabular}

\begin{tabular}{|c|c|c|c|c|c|c|c|}
\hline \multicolumn{8}{|c|}{ SW06 Electrode Points Interpolation Table } \\
\hline $\begin{array}{l}\text { Elect- } \\
\text { rode }\end{array}$ & $\begin{array}{c}\text { Accu- } \\
\text { racy } \\
\text { (m) }\end{array}$ & $\begin{array}{c}\text { Measured X } \\
\text { (WGS) }\end{array}$ & $\begin{array}{c}\text { Measured Y } \\
\text { (WGS) }\end{array}$ & $\begin{array}{c}\text { Measured Z } \\
(\mathbf{m})\end{array}$ & $\begin{array}{c}\text { Interpolated X } \\
\text { (WGS) }\end{array}$ & $\begin{array}{c}\text { Interpolated Y } \\
\text { (WGS) }\end{array}$ & DEM Z (m) \\
\hline 1 & 3.837 & -78.83693486 & 38.25330956 & 407.3852694 & -78.83698589 & 38.25334458 & 399.907898 \\
\hline 2 & 6.865 & -78.8368912 & 38.25337065 & 404.1850106 & -78.83693805 & 38.25338722 & 400.5484314 \\
\hline 3 & 3.24 & -78.83682662 & 38.25341243 & 405.3139174 & -78.83689408 & 38.25342738 & 401.0957031 \\
\hline 4 & 3.922 & -78.83681887 & 38.25344741 & 416.6824651 & -78.83684927 & 38.25346831 & 400.8707275 \\
\hline 5 & 3.219 & -78.83679477 & 38.25348177 & 409.3681919 & -78.83680532 & 38.25350845 & 401.0626831 \\
\hline 6 & 3.421 & -78.83672683 & 38.2535304 & 407.0762794 & -78.83675979 & 38.25355003 & 402.7197266 \\
\hline 7 & 3.275 & -78.8366816 & 38.25356494 & 409.5149355 & -78.83671508 & 38.25359086 & 405.1816101 \\
\hline 8 & 4.788 & -78.83667144 & 38.25362233 & 410.153316 & -78.83666991 & 38.25363211 & 406.7475281 \\
\hline 9 & 5.103 & -78.83662743 & 38.25368536 & 417.9284712 & -78.83662488 & 38.25367324 & 407.9828186 \\
\hline 10 & 4.626 & -78.83658452 & 38.25370382 & 425.4177997 & -78.8365803 & 38.25371395 & 408.954895 \\
\hline 11 & 4.564 & -78.83654893 & 38.2537787 & 410.0204268 & -78.83653489 & 38.25375542 & 409.9763794 \\
\hline 12 & 5.063 & -78.83647695 & 38.25377617 & 420.3380555 & -78.83649042 & 38.25379603 & 410.9480591 \\
\hline 13 & 3.056 & -78.83643676 & 38.25385168 & 414.4750084 & -78.83644553 & 38.25383703 & 411.9129028 \\
\hline 14 & 3.112 & -78.8363659 & 38.25387989 & 417.5140539 & -78.83639882 & 38.25387968 & 413.198822 \\
\hline
\end{tabular}

\begin{tabular}{|l|l|l|l|l|l|}
\hline \multicolumn{7}{|c|}{ SW07 Electrode Points Interpolation Table } \\
\hline & $\begin{array}{c}\text { Accuracy } \\
\text { (m) }\end{array}$ & $\begin{array}{c}\text { Measured X } \\
\text { (WGS) }\end{array}$ & $\begin{array}{c}\text { Measured Y } \\
\text { (WGS) }\end{array}$ & $\begin{array}{c}\text { Measured Z } \\
\text { (m) }\end{array}$ & DEM Z (m) \\
\hline 1 & 0.025 & -78.83665378 & 38.25321607 & 403.7872817 & 402.9119873 \\
\hline 2 & 0.022 & -78.83661859 & 38.25326479 & 404.2768335 & 403.5241089 \\
\hline 3 & 0.532 & -78.83657551 & 38.25331662 & 407.1995698 & 404.2385254 \\
\hline 4 & 0.021 & -78.83655197 & 38.25336263 & 405.3744433 & 404.5239563 \\
\hline 5 & 0.021 & -78.83651601 & 38.2534102 & 405.9335933 & 405.171051 \\
\hline 6 & 0.703 & -78.83647925 & 38.25346522 & 409.722184 & 405.929718 \\
\hline 7 & 0.033 & -78.83644843 & 38.25350915 & 409.5040454 & 406.7532044 \\
\hline 8 & 0.034 & -78.83641938 & 38.25355857 & 409.8737251 & 407.5138245 \\
\hline 9 & 0.019 & -78.8363867 & 38.25360339 & 409.8156394 & 408.1489258 \\
\hline 10 & 0.028 & -78.83634453 & 38.25365197 & 409.9126318 & 409.0856934 \\
\hline 11 & 0.026 & -78.8363048 & 38.2536994 & 411.7762955 & 410.2386169 \\
\hline 12 & 0.134 & -78.83624976 & 38.25374893 & 421.3903598 & 411.6100769 \\
\hline 13 & 0.293 & -78.83622692 & 38.25378998 & 417.0270353 & 412.3597107 \\
\hline 14 & 0.021 & -78.83619912 & 38.25384008 & 414.0717224 & 413.2416382 \\
\hline
\end{tabular}

\begin{tabular}{|l|c|c|l|l|l|}
\hline \multicolumn{7}{|c|}{ GCDD01-06 Electrode Points Interpolation Table } \\
\hline & $\begin{array}{c}\text { Accuracy } \\
\text { (m) }\end{array}$ & $\begin{array}{c}\text { Measured X } \\
\text { (WGS) }\end{array}$ & $\begin{array}{c}\text { Measured Y } \\
\text { (WGS) }\end{array}$ & $\begin{array}{c}\text { Measured Z } \\
(\mathbf{m})\end{array}$ & DEM Z (m) \\
\hline Electrode & 0.309 & -78.83739242 & 38.2590991 & 398.2061106 & 394.1900635 \\
\hline 1 & 0.351 & -78.83732964 & 38.25913035 & 400.66099 & 394.341919 \\
\hline 2 &
\end{tabular}




\begin{tabular}{|l|l|l|l|l|l|}
\hline 3 & 0.291 & -78.83731544 & 38.25918961 & 398.1586989 & 394.0958557 \\
\hline 4 & 0.298 & -78.83729478 & 38.25924627 & 398.5424727 & 393.8347168 \\
\hline 5 & 0.246 & -78.83726502 & 38.25928992 & 398.6359554 & 393.8656006 \\
\hline 6 & 0.22 & -78.83723154 & 38.2593451 & 399.2936598 & 393.4415588 \\
\hline 7 & 0.036 & -78.83716673 & 38.25939081 & 399.9569614 & 392.9602356 \\
\hline 8 & 0.286 & -78.83716967 & 38.25943031 & 398.7900574 & 393.6126709 \\
\hline 9 & 0.29 & -78.83713209 & 38.25949454 & 399.772404 & 394.9227905 \\
\hline 10 & 0.294 & -78.83708634 & 38.25952886 & 398.5330338 & 395.5932922 \\
\hline 11 & 0.023 & -78.83704976 & 38.25959055 & 399.6225621 & 396.0577393 \\
\hline 12 & 0.059 & -78.83700691 & 38.25964627 & 399.8886321 & 396.3844299 \\
\hline 13 & 0.181 & -78.83696498 & 38.25967053 & 398.3938408 & 396.65448 \\
\hline 14 & 0.187 & -78.83695566 & 38.25971755 & 398.1718087 & 396.2907715 \\
\hline
\end{tabular}

\begin{tabular}{|c|c|c|c|c|c|}
\hline \multicolumn{6}{|c|}{ GCDD09 Electrode Points Interpolation Table } \\
\hline Electrode & $\begin{array}{c}\text { Accuracy } \\
(\mathrm{m})\end{array}$ & $\begin{array}{c}\text { Measured X } \\
\text { (WGS) }\end{array}$ & $\begin{array}{c}\text { Measured Y } \\
\text { (WGS) }\end{array}$ & $\begin{array}{c}\text { Measured Z } \\
(\mathbf{m})\end{array}$ & DEM Z (m) \\
\hline 1 & 0.224 & -78.83649959 & 38.26082547 & 392.5313784 & 389.7948608 \\
\hline 2 & 0.033 & -78.83650434 & 38.26078971 & 394.9449324 & 390.0802918 \\
\hline 3 & 0.288 & -78.83654044 & 38.26071659 & 394.1506685 & 390.4938049 \\
\hline 4 & 0.289 & -78.83656894 & 38.26066688 & 394.598105 & 390.8081055 \\
\hline 5 & 0.252 & -78.83659744 & 38.26061557 & 395.7050092 & 391.2645874 \\
\hline 6 & 0.024 & -78.83662382 & 38.26057091 & 392.0229848 & 391.4723511 \\
\hline 7 & 0.246 & -78.83665997 & 38.26052818 & 395.0677972 & 391.5449524 \\
\hline 8 & 0.028 & -78.83667914 & 38.26046851 & 392.3211111 & 391.5760498 \\
\hline 9 & 0.033 & -78.8367123 & 38.26041455 & 396.5171235 & 391.2811279 \\
\hline 10 & 0.06 & -78.83673304 & 38.26035939 & 394.5231001 & 390.578186 \\
\hline 11 & 0.071 & -78.83675656 & 38.26030562 & 393.3216113 & 389.5390625 \\
\hline 12 & 0.091 & -78.83677974 & 38.26025745 & 393.0231464 & 387.972168 \\
\hline 13 & 0.271 & -78.83679653 & 38.26020146 & 390.8082303 & 389.1753845 \\
\hline 14 & 0.252 & -78.83681229 & 38.26014325 & 394.2305474 & 390.8504028 \\
\hline 15 & 0.022 & -78.83683054 & 38.26008661 & 396.8120819 & 392.3803101 \\
\hline 16 & 0.057 & -78.8368535 & 38.26003572 & 398.1039579 & 393.0957642 \\
\hline 17 & 0.018 & -78.83687583 & 38.25998842 & 394.0762781 & 393.5158691 \\
\hline 18 & 0.154 & -78.83690118 & 38.25994354 & 398.9687485 & 393.8464356 \\
\hline 19 & 0.115 & -78.83692657 & 38.25989653 & 402.0352004 & 394.3364563 \\
\hline 20 & 0.182 & -78.83694645 & 38.25983964 & 397.8336022 & 395.171814 \\
\hline 21 & 0.294 & -78.83698117 & 38.25978042 & 399.2529026 & 395.5921021 \\
\hline 22 & 0.026 & -78.83699664 & 38.25972661 & 396.4824497 & 395.9786377 \\
\hline 23 & 0.19 & -78.83702192 & 38.25967915 & 399.0504852 & 396.1086426 \\
\hline 24 & 0.186 & -78.83704319 & 38.2596223 & 397.8185665 & 396.0265808 \\
\hline 25 & 0.12 & -78.83706913 & 38.25957278 & 397.8021657 & 395.7996521 \\
\hline 26 & 0.086 & -78.83709712 & 38.25952238 & 397.5357164 & 395.396759 \\
\hline 27 & 0.158 & -78.83713138 & 38.25946883 & 399.2057103 & 394.8550415 \\
\hline 28 & 0.193 & -78.83715682 & 38.259411 & 394.4326833 & 393.2019959 \\
\hline 29 & 0.03 & -78.83718329 & 38.25936416 & 393.6948175 & 393.0103455 \\
\hline 30 & $<$ null >* & -78.83721707 & 38.2593176 & 394.1885655 & 393.9676514 \\
\hline 31 & 0.039 & -78.8372512 & 38.2592674 & 394.6823133 & 394.3553467 \\
\hline 32 & 0.023 & -78.83728008 & 38.2592163 & 394.8099036 & 394.1480103 \\
\hline 33 & 0.793 & -78.83732583 & 38.25915732 & 401.4539768 & 394.1910095 \\
\hline 34 & 0.026 & -78.83734021 & 38.25911435 & 394.900695 & 394.4719238 \\
\hline 35 & 0.281 & -78.83737556 & 38.25906468 & 395.7812631 & 394.8728333 \\
\hline 36 & 0.285 & -78.83741011 & 38.25901192 & 397.3975696 & 395.1816711 \\
\hline 37 & 0.023 & -78.83744119 & 38.25897062 & 395.9961315 & 395.3259277 \\
\hline 38 & $<$ null $>*$ & -78.83746642 & 38.25891332 & 398.2731295 & 395.6531677 \\
\hline 39 & $<$ null $>*$ & -78.83748895 & 38.25886724 & 397.922776 & 395.8720093 \\
\hline 40 & 2.283 & -78.83752633 & 38.25881497 & 398.6234888 & 395.9248047 \\
\hline 41 & $<$ null $>*$ & -78.83756579 & 38.25877448 & 397.359126 & 395.7531128 \\
\hline 42 & 0.028 & -78.83761729 & 38.25872833 & 396.0947632 & 395.3870544 \\
\hline 43 & 0.045 & -78.83764946 & 38.25868569 & 398.3813212 & 395.2350464 \\
\hline 44 & 0.033 & -78.83766296 & 38.25865277 & 399.3905859 & 395.1055603 \\
\hline 45 & 0.283 & -78.83773902 & 38.25857816 & 400.8103175 & 394.8631897 \\
\hline
\end{tabular}




\begin{tabular}{|l|l|l|l|l|l|}
\hline 46 & 0.393 & -78.83777071 & 38.25852824 & 397.1771314 & 394.7058106 \\
\hline 47 & 0.034 & -78.83780915 & 38.25848576 & 395.2140935 & 394.5358582 \\
\hline 48 & 0.051 & -78.83786792 & 38.25842911 & 398.0760989 & 394.0229797 \\
\hline 49 & 0.031 & -78.83787895 & 38.25838866 & 394.7458959 & 394.1111755 \\
\hline 50 & 0.034 & -78.83791853 & 38.2583417 & 394.5056812 & 393.7759705 \\
\hline 51 & 0.29 & -78.83796617 & 38.25828718 & 401.3886851 & 393.2749329 \\
\hline 52 & 0.033 & -78.8379912 & 38.25824723 & 393.9362921 & 393.1659546 \\
\hline 53 & 0.273 & -78.8380267 & 38.25819433 & 398.7785038 & 392.8896179 \\
\hline 54 & 0.189 & -78.83804753 & 38.25815111 & 397.4920744 & 392.8037415 \\
\hline 55 & 0.411 & -78.83809911 & 38.25809957 & 396.7021814 & 392.1688843 \\
\hline 56 & 0.288 & -78.83813344 & 38.25806652 & 393.0921435 & 391.74823 \\
\hline
\end{tabular}

$*<$ null $>$ indicates an interpolated point.

\begin{tabular}{|c|c|c|c|c|c|}
\hline \multicolumn{7}{|c|}{ GCDD10 Electrode Points Interpolation Table } \\
\hline & $\begin{array}{c}\text { Accuracy } \\
\text { Electrode }\end{array}$ & $\begin{array}{c}\text { Measured X } \\
\text { (WGS) }\end{array}$ & $\begin{array}{c}\text { Measured Y } \\
\text { (WGS) }\end{array}$ & $\begin{array}{c}\text { Measured Z } \\
(\mathbf{m})\end{array}$ & DEM Z (m) \\
\hline 1 & 0.028 & -78.83807304 & 38.25975837 & 377.7391336 & 377.0694275 \\
\hline 2 & 0.026 & -78.83801117 & 38.25973484 & 378.3816671 & 377.8136292 \\
\hline 3 & 0.044 & -78.83794737 & 38.25971074 & 379.6060257 & 378.6238098 \\
\hline 4 & 0.025 & -78.83788505 & 38.25968789 & 379.750481 & 379.2658081 \\
\hline 5 & 0.027 & -78.83782316 & 38.25966166 & 380.7024879 & 380.0577393 \\
\hline 6 & 0.044 & -78.83775764 & 38.25963935 & 381.8898853 & 381.0479736 \\
\hline 7 & 0.027 & -78.83769739 & 38.25961405 & 382.796512 & 382.1622009 \\
\hline 8 & 0.051 & -78.8376395 & 38.25958866 & 384.9306358 & 383.74823 \\
\hline 9 & 0.042 & -78.83757903 & 38.25956544 & 386.6144949 & 385.5639038 \\
\hline 10 & 0.026 & -78.8375173 & 38.25954332 & 388.5937409 & 388.0659485 \\
\hline 11 & 0.029 & -78.83745995 & 38.25951481 & 390.3227558 & 389.7697754 \\
\hline 12 & 0.25 & -78.83738505 & 38.25949484 & 393.8444195 & 391.2911072 \\
\hline 13 & 0.274 & -78.83734263 & 38.2594661 & 395.327808 & 391.9629822 \\
\hline 14 & 0.03 & -78.83727426 & 38.25943512 & 393.2833219 & 392.7526856 \\
\hline 15 & 0.026 & -78.83720532 & 38.25940349 & 393.2336044 & 392.6613464 \\
\hline 16 & 0.546 & -78.83714029 & 38.25938381 & 395.1820805 & 393.5989075 \\
\hline 17 & 0.053 & -78.83707952 & 38.25935606 & 396.2842574 & 395.3562927 \\
\hline 18 & 0.032 & -78.83702564 & 38.25932574 & 397.6313008 & 396.9958801 \\
\hline 19 & 0.027 & -78.83696371 & 38.25930062 & 398.4746485 & 397.9064636 \\
\hline 20 & 0.033 & -78.83690418 & 38.25927574 & 404.8331803 & 398.8129578 \\
\hline 21 & 0.032 & -78.83684417 & 38.25924833 & 405.5144829 & 399.6606751 \\
\hline 22 & 0.229 & -78.836785 & 38.25921406 & 404.5791626 & 400.5784607 \\
\hline 23 & 0.284 & -78.83673009 & 38.25918601 & 404.934733 & 401.0968628 \\
\hline 24 & 0.192 & -78.83667894 & 38.25915404 & 408.8896174 & 401.5058594 \\
\hline 25 & 0.279 & -78.83661477 & 38.25912576 & 410.2955003 & 401.9500122 \\
\hline 26 & 0.28 & -78.83656064 & 38.25910545 & 411.6259108 & 402.3065186 \\
\hline 27 & 0.191 & -78.83649169 & 38.25907156 & 409.3591861 & 402.5003967 \\
\hline 28 & 0.112 & -78.83642661 & 38.25904756 & 409.4456063 & 402.6680298 \\
\hline
\end{tabular}




\section{Appendix C}

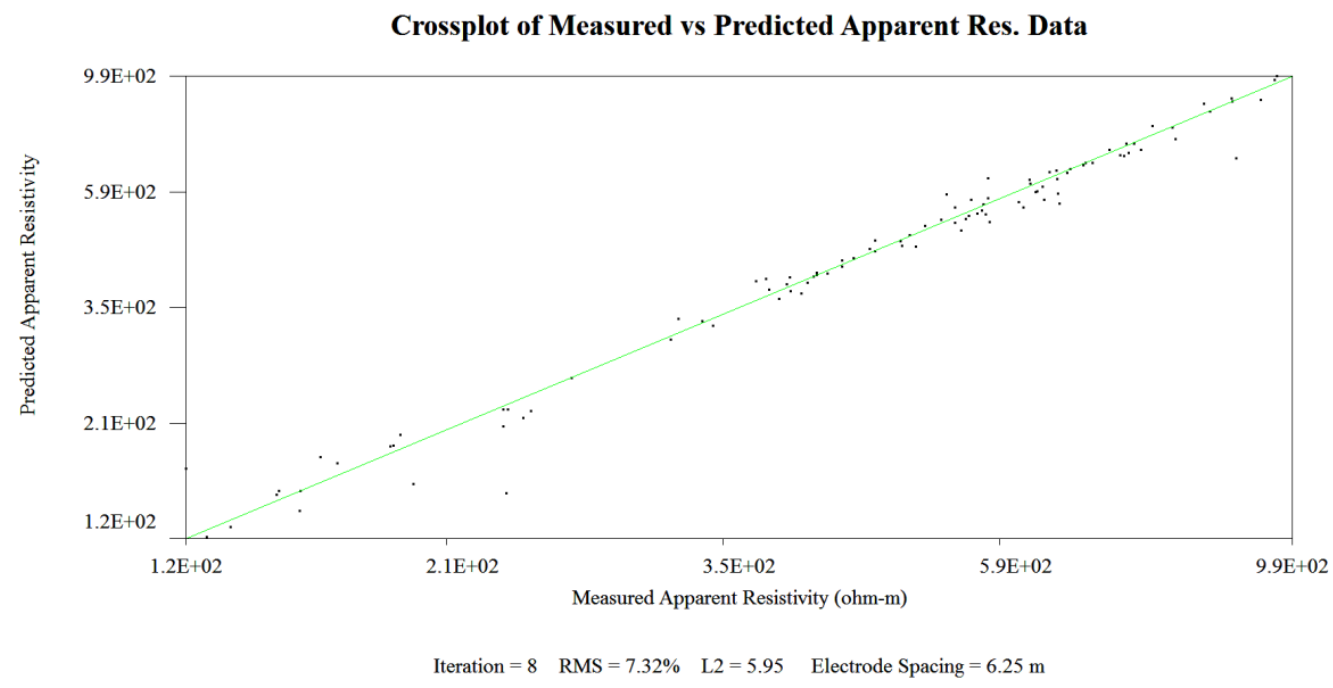

Crossplot for SW05 shows there are outlier data points that may need to be removed.

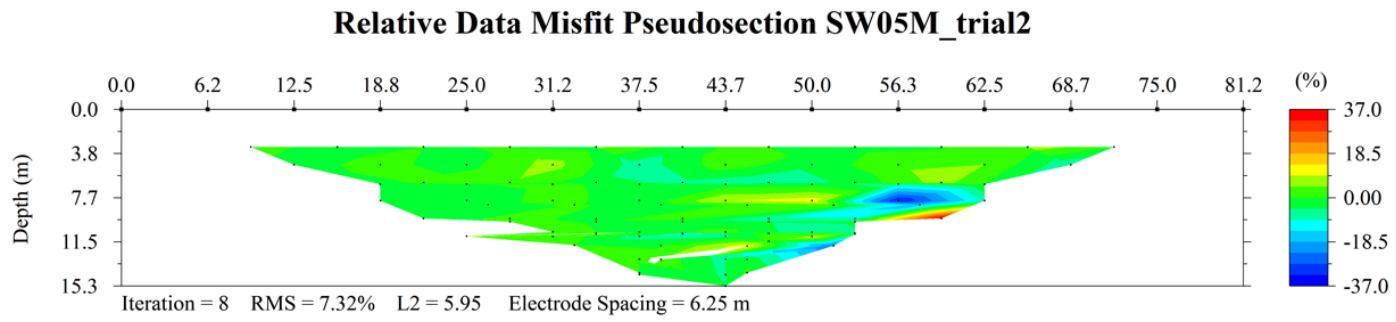

The relative data misfit pseudosection for SW05 shows there is substantial misfit data between 43 and 62.5 meters.

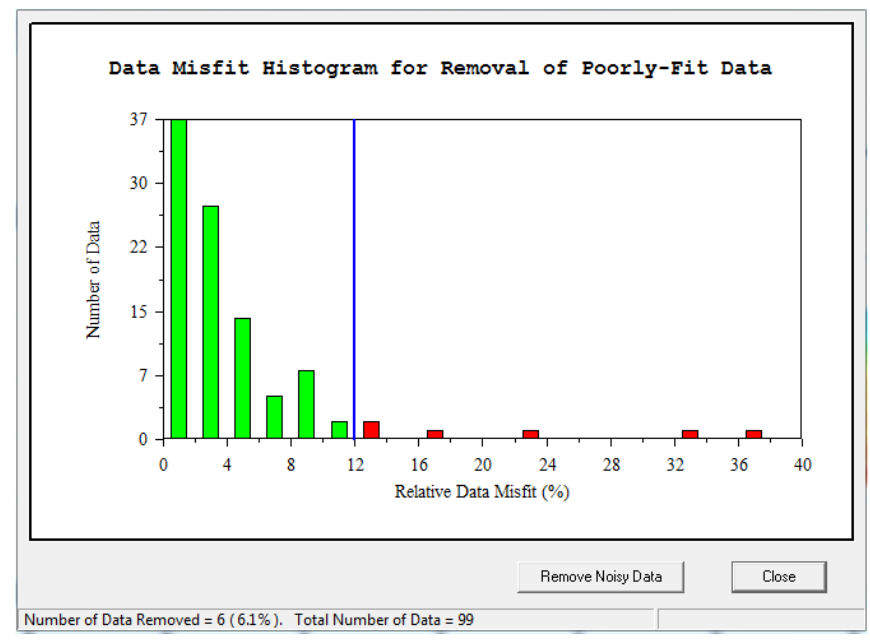

The data misfit histogram for SW05 indicates $6.1 \%$ of the data has been flagged for removal. 


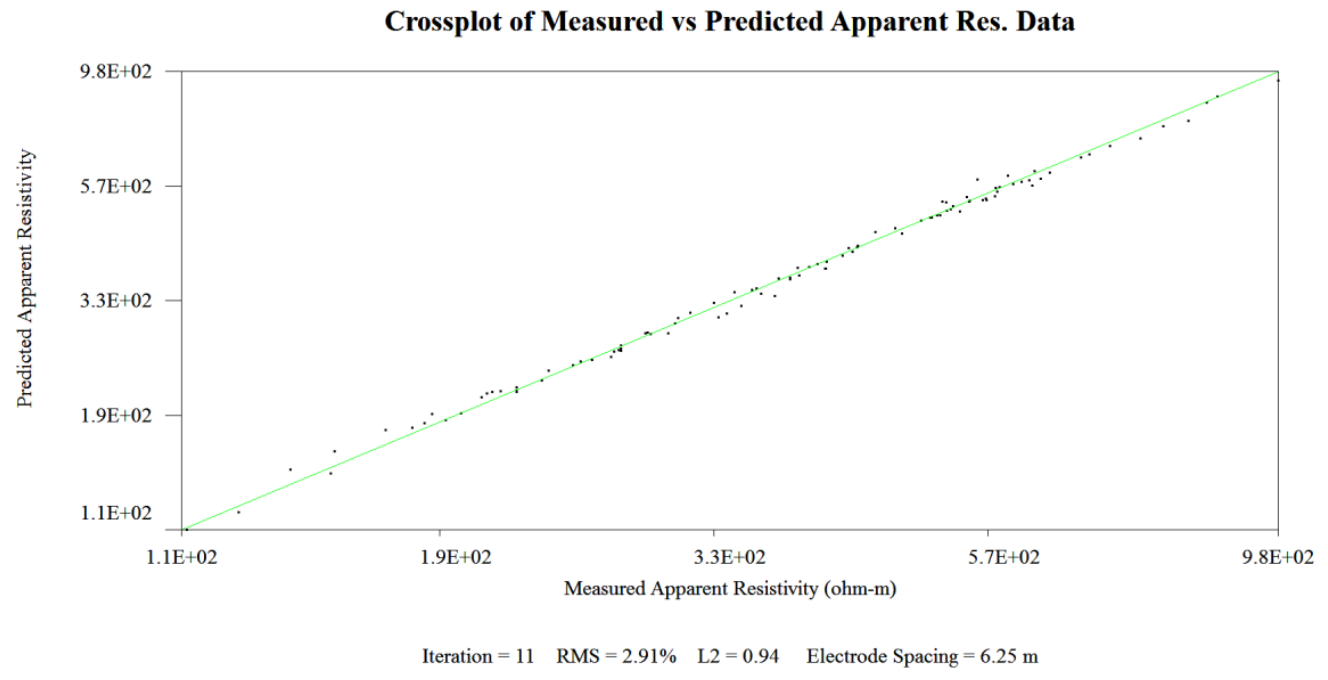

Cossplot for SW06 shows few data outliers indicating that misfit data removal may or may not be necessary.

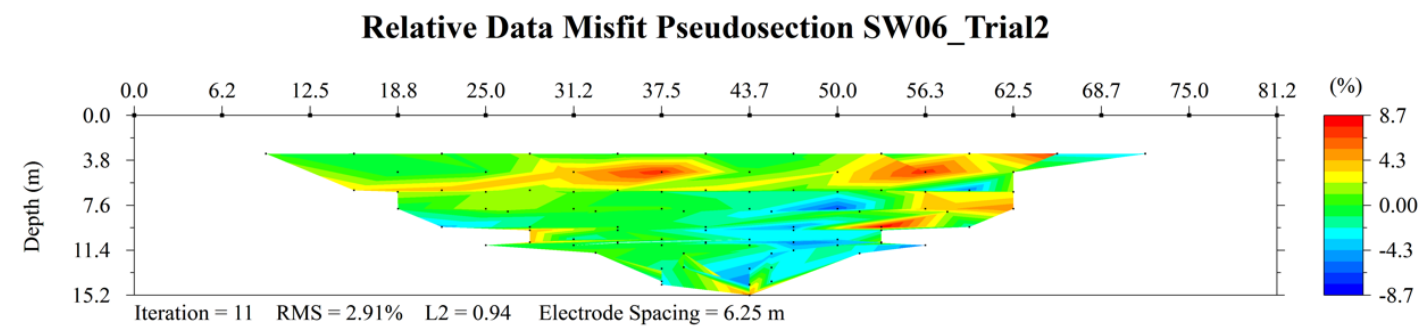

The relative data misfit pseudosection for SW06 suggests noise from misfit data may be minor to moderate due to a general spread of $\sim 8 \%$ relative data misfit outliers throughout the profile. Removal of misfit data may slightly improve the results.

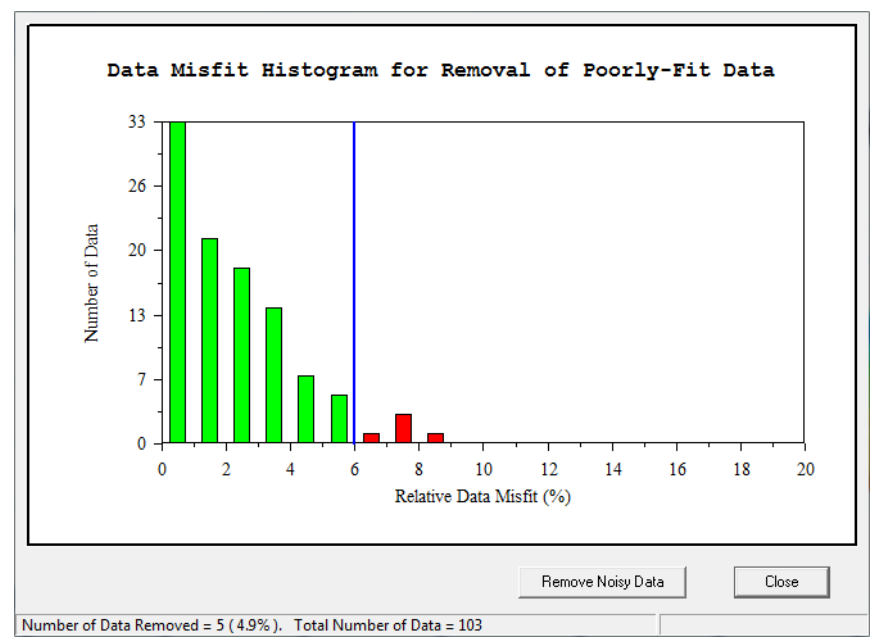

The data misfit histogram for SW06 indicates $4.9 \%$ of the data has been flagged for removal. 


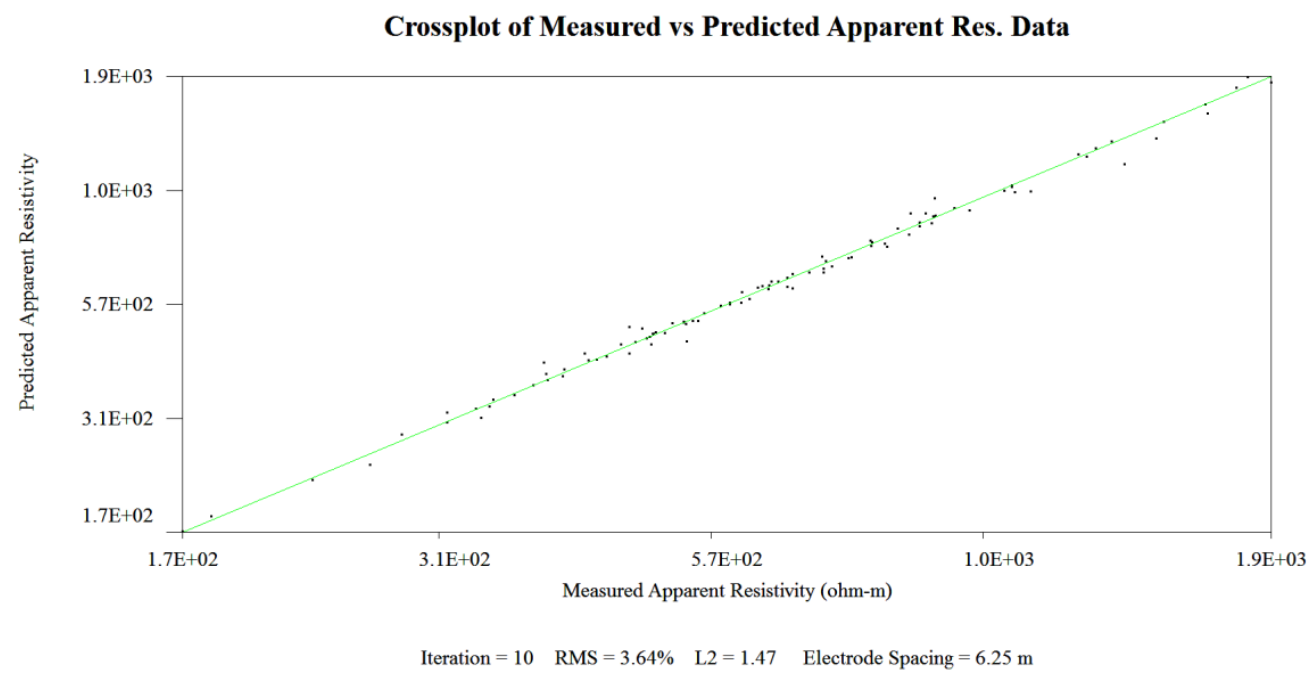

Cossplot for SW07 shows some data outliers indicating that misfit data removal may be necessary.

Relative Data Misfit Pseudosection SW07_trial1

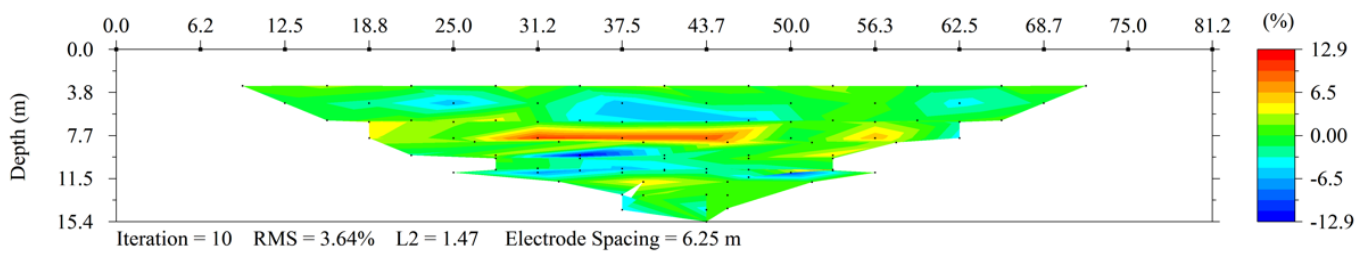

The relative data misfit pseudosection for SW07 suggests noise from misfit data may be moderate due to a general concentration of $\sim 12 \%$ relative data misfit outliers between 25 and 50 meters in the profile. Removal of misfit data may improve the results.

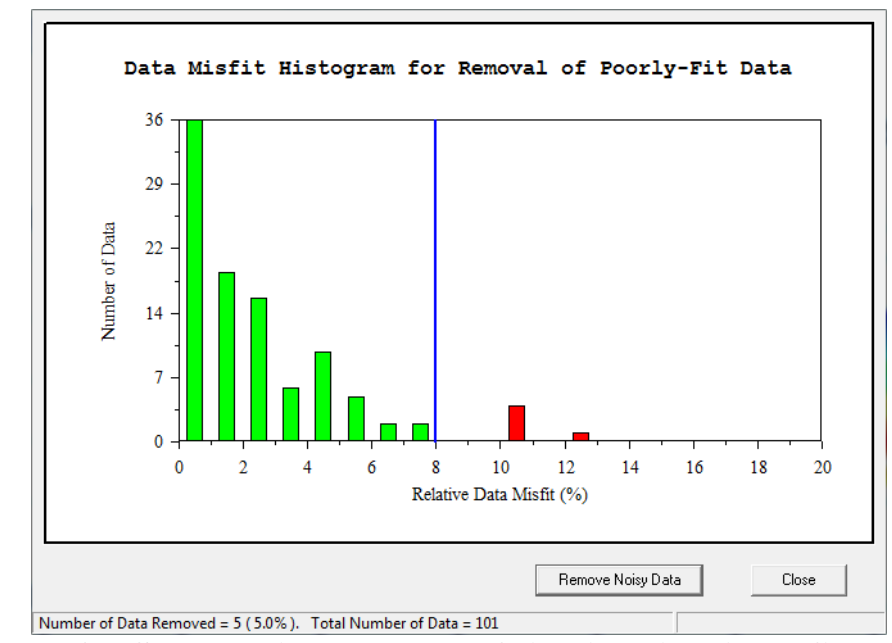

The data misfit histogram for SW06 indicates 5.0\% of the data has been flagged for removal. 


\section{Appendix D}

\begin{tabular}{|c|c|c|c|c|c|c|c|}
\hline \multicolumn{8}{|c|}{ Strike \& Dip Data Point Elevation / Fold Axis Interpolation Table } \\
\hline $\begin{array}{l}\text { Accu- } \\
\text { racy } \\
(\mathrm{m})\end{array}$ & $\begin{array}{l}\text { Measured } \\
\text { X (WGS) }\end{array}$ & $\begin{array}{l}\text { Measured } \\
\text { Y (WGS) }\end{array}$ & $\begin{array}{l}\text { Measured } \\
\text { Z (m) }\end{array}$ & $\begin{array}{l}\text { D to Cross } \\
\text { Section (m) }\end{array}$ & $\begin{array}{c}\text { Converted } \\
\text { Elevation }(\mathrm{m})\end{array}$ & Strike/ Dip & Obseervation \\
\hline 0.321 & $\begin{array}{c}- \\
78.83553491\end{array}$ & 38.25738313 & 381.0212529 & 487.3239437 & 250.4431957 & $222 / 7$ & sparite \\
\hline 0.048 & $\begin{array}{c}- \\
78.83495689\end{array}$ & 38.25672931 & 388.4478476 & 439.4366197 & 270.7011602 & $<$ null >* & ALD \\
\hline 0.196 & 78.83465911 & 38.25662483 & 374.9869699 & 442.2535211 & 256.4854961 & $<$ null >* & $\begin{array}{c}\text { micrite under } \\
\text { ALM }\end{array}$ \\
\hline 9.451 & $\begin{array}{c}- \\
78.83470084\end{array}$ & 38.25659407 & 375.1781991 & 436.6197183 & 258.1862982 & $<$ null >* & $\begin{array}{c}\text { contact } / \mathrm{w} \\
\text { FID5 ALM blw } \\
\sim 1 \mathrm{~m} \text { srite }\end{array}$ \\
\hline 0.323 & $\begin{array}{c}- \\
78.83472197\end{array}$ & 38.25656784 & 382.1211905 & 433.8028169 & 265.884076 & $84 / 15$ & $\begin{array}{c}\text { srite at } \mathrm{P}, \sim 8 \mathrm{~m} \\
\text { abve }=\mathrm{ALD} \mathrm{w} / \\
\text { chert nod, } \sim 2 \mathrm{~m} \\
\text { blw }=\mathrm{ALM}\end{array}$ \\
\hline 0.03 & $\begin{array}{c}- \\
78.83491188 \\
\end{array}$ & 38.25634847 & 395.6698432 & 402.8169014 & 287.7353797 & $80 / 10$ & ALD \\
\hline 0.182 & $\begin{array}{c}- \\
78.83530674 \\
\end{array}$ & 38.25577483 & 423.3692776 & 332.3943662 & 334.3044756 & $135 / 9$ & ALD \\
\hline 0.025 & $\begin{array}{c}- \\
78.83565323\end{array}$ & 38.25495265 & 420.5329063 & 236.6197183 & 357.1308439 & $73 / 15$ & ALD \\
\hline 0.057 & -78.8366508 & 38.25345146 & 406.9670593 & 50.70422535 & 393.3809031 & $35 / 21$ & $\begin{array}{l}\mathrm{ALD}, \text { light } \\
\text { grey }\end{array}$ \\
\hline 0.03 & $\begin{array}{c}- \\
78.83623149\end{array}$ & 38.25317776 & 404.4435095 & 36.61971831 & 394.6312856 & $194 / 43$ & $\begin{array}{l}\text { mic-sparite, } \\
\text { grey, no def. } \\
\text { grain size. }\end{array}$ \\
\hline 0.027 & $\begin{array}{c}- \\
78.83633055 \\
\end{array}$ & 38.25275148 & 399.5469198 & 11.26760563 & 402.5660656 & $182 / 77$ & $\begin{array}{l}\text { ALDs with } \\
\text { chert nodules }\end{array}$ \\
\hline 0.338 & 78.83594571 & 38.25703597 & 410.7193209 & 436.6197183 & 293.72742 & $95 / 43$ & $\begin{array}{c}\text { AIMs with } \\
\text { chert nodules }\end{array}$ \\
\hline 0.333 & $\begin{array}{c}- \\
78.83594627 \\
\end{array}$ & 38.25703548 & 410.5988429 & 436.6197183 & 293.606942 & $95 / 43$ & $\begin{array}{c}\text { AlMs with } \\
\text { chert nodules }\end{array}$ \\
\hline
\end{tabular}

$*<$ null $>$ indicates the absence of a strike and dip measurement 


\section{Appendix E}
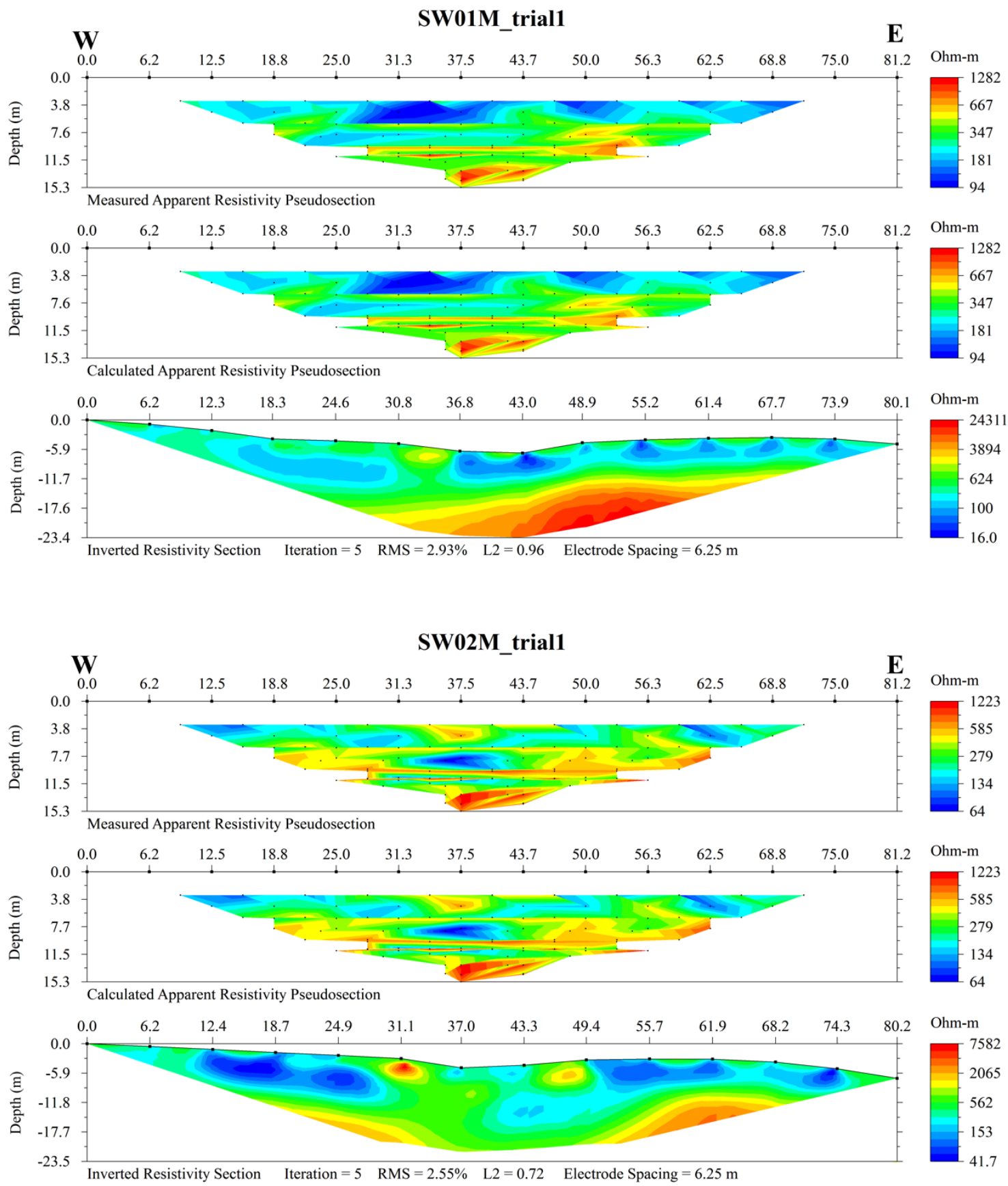

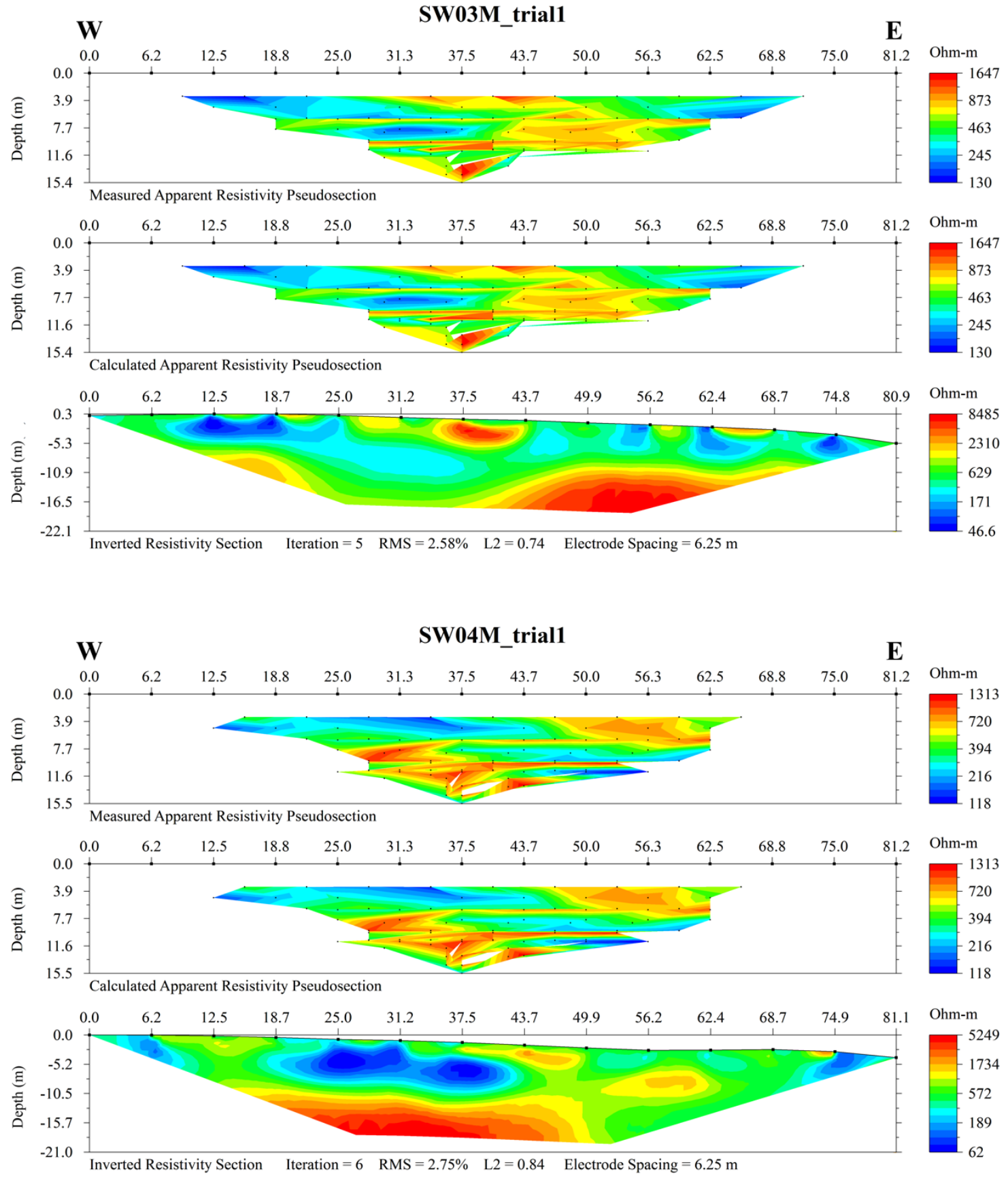

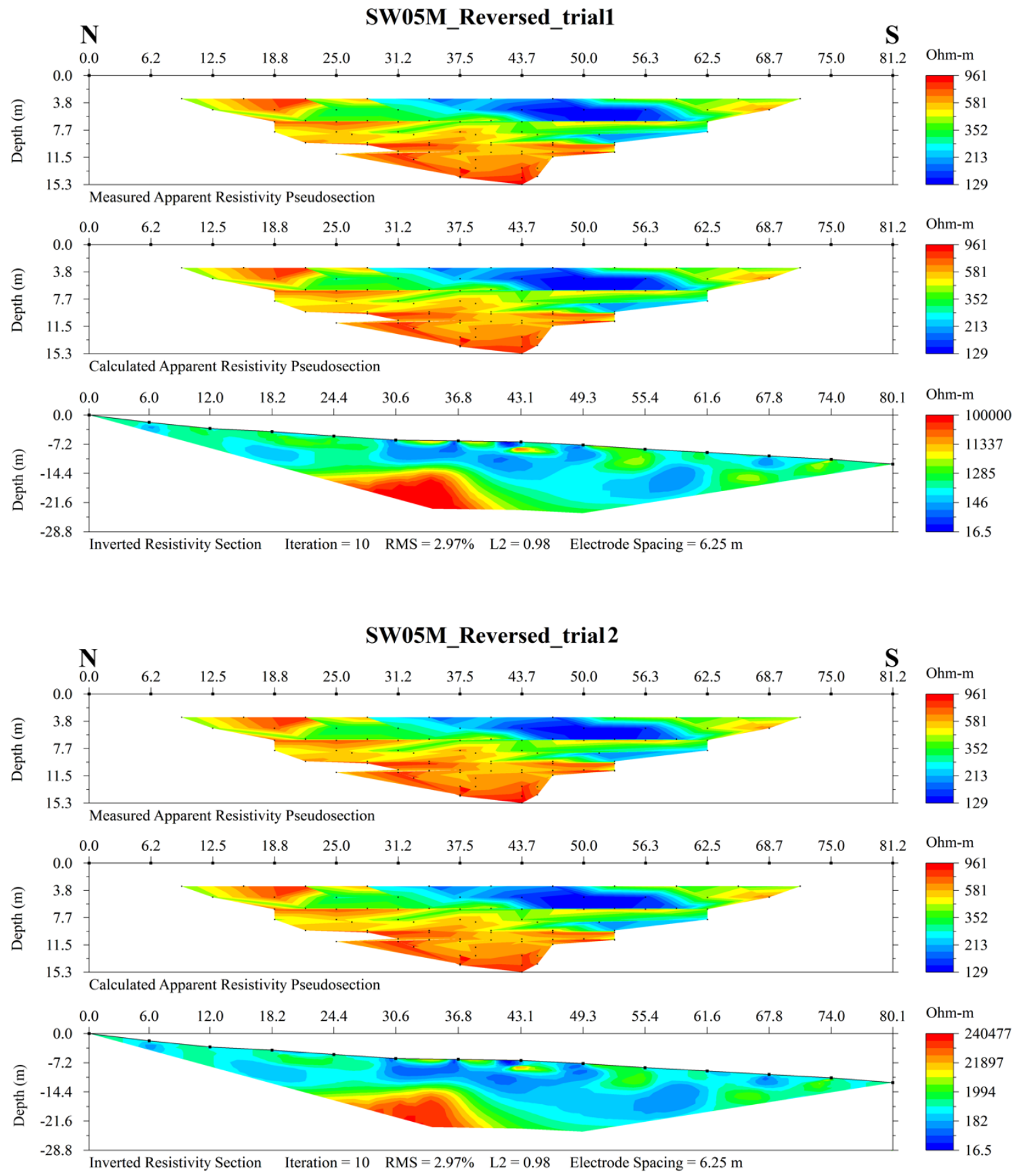

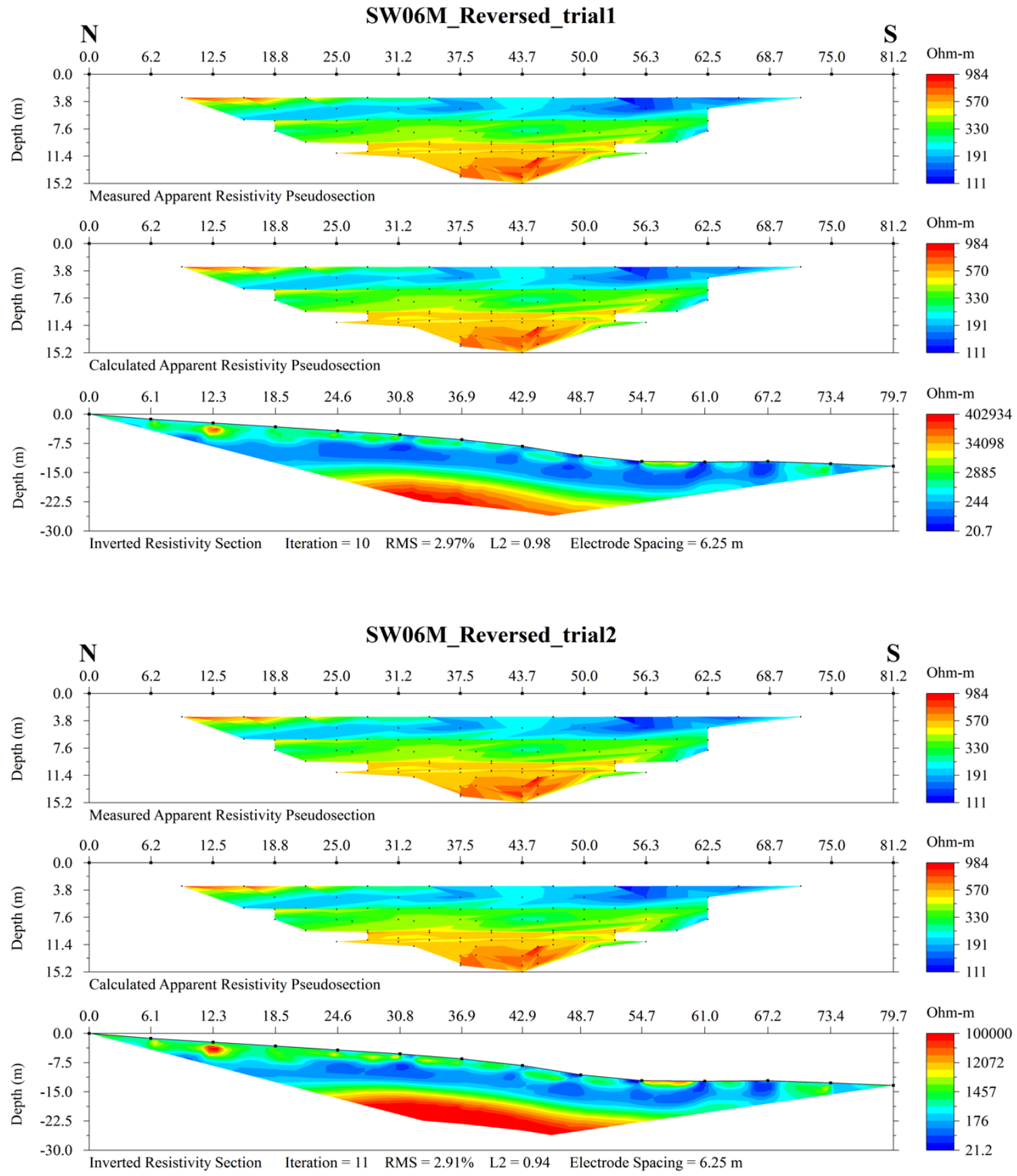

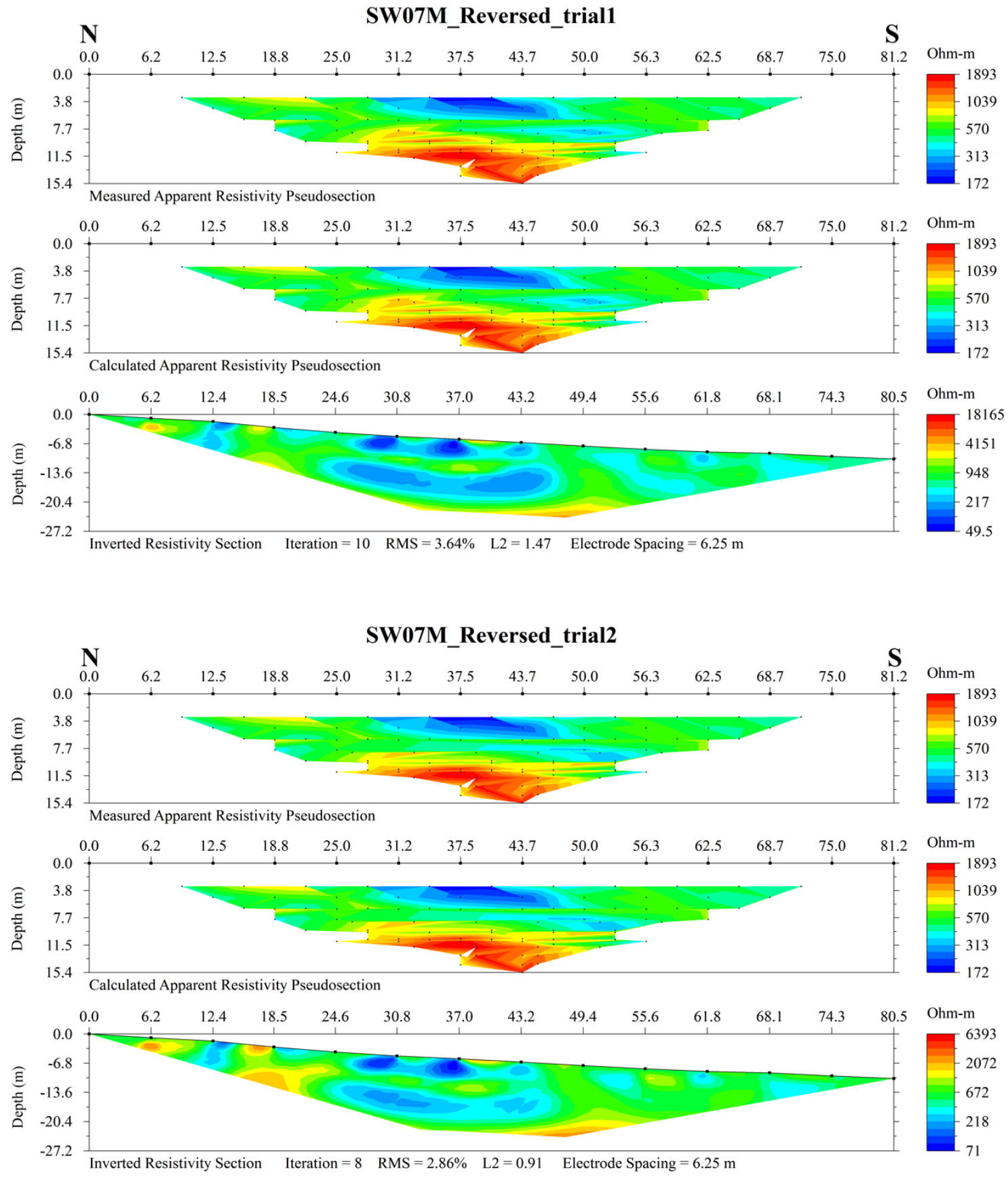


\section{Appendix F}
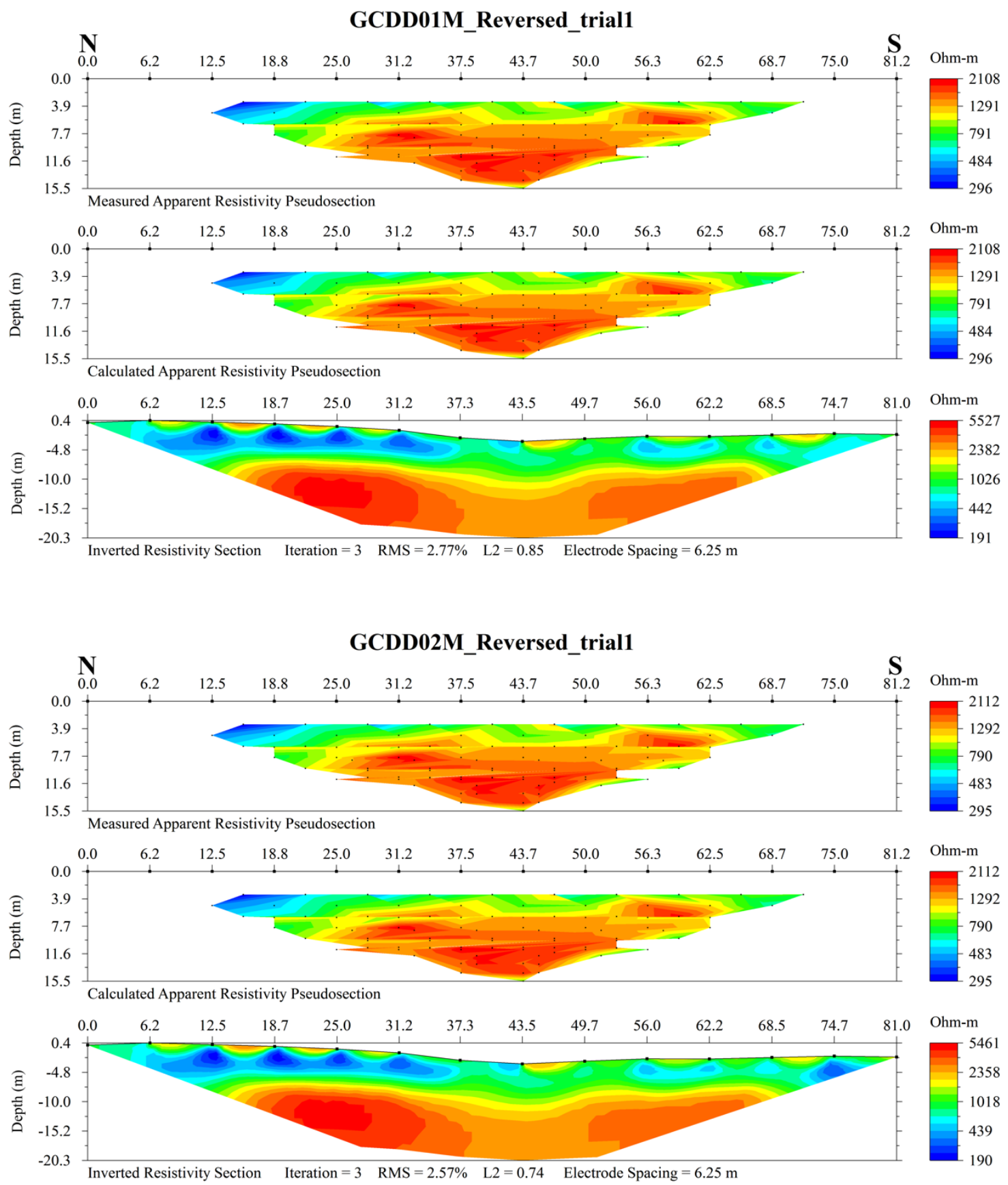

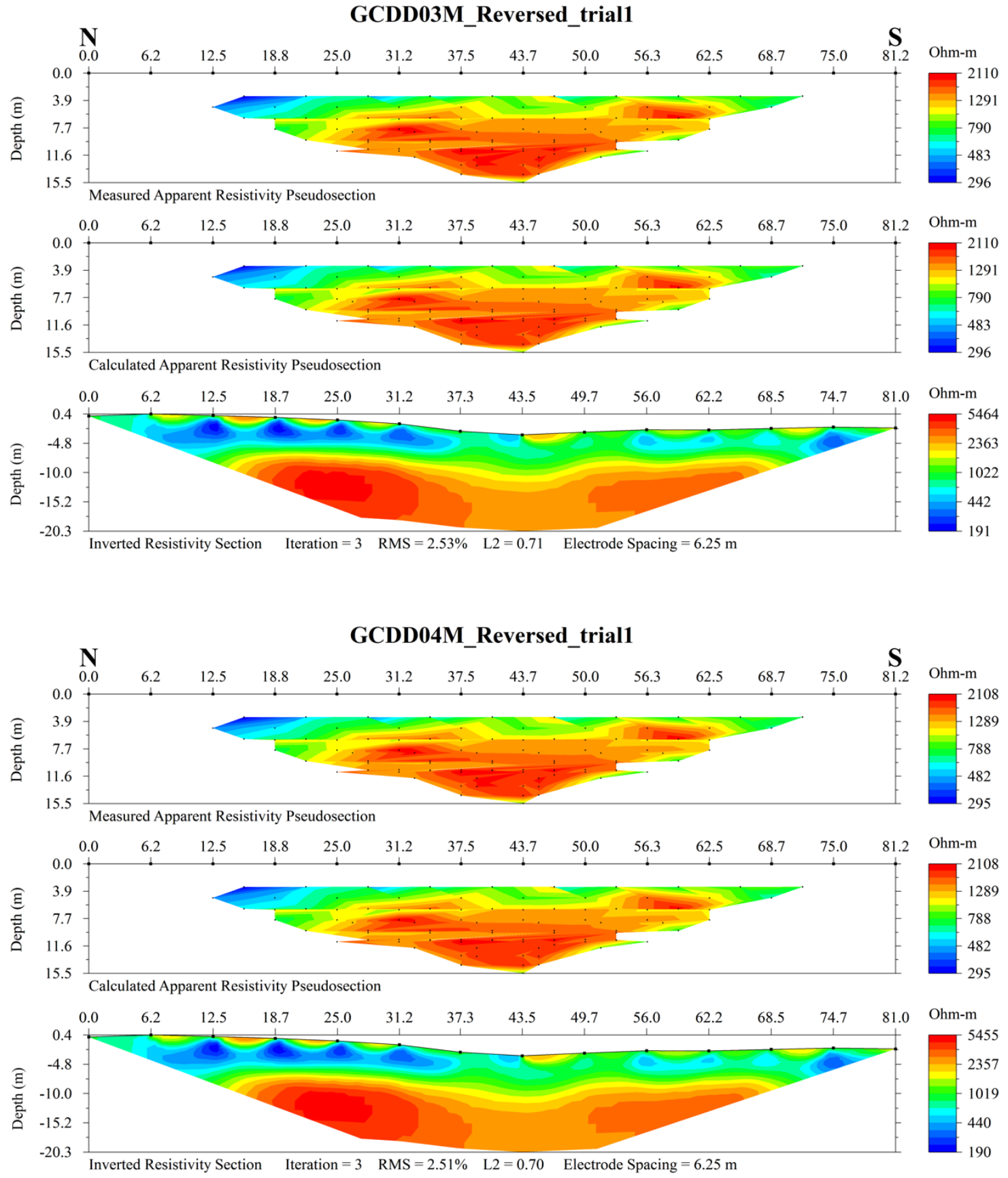

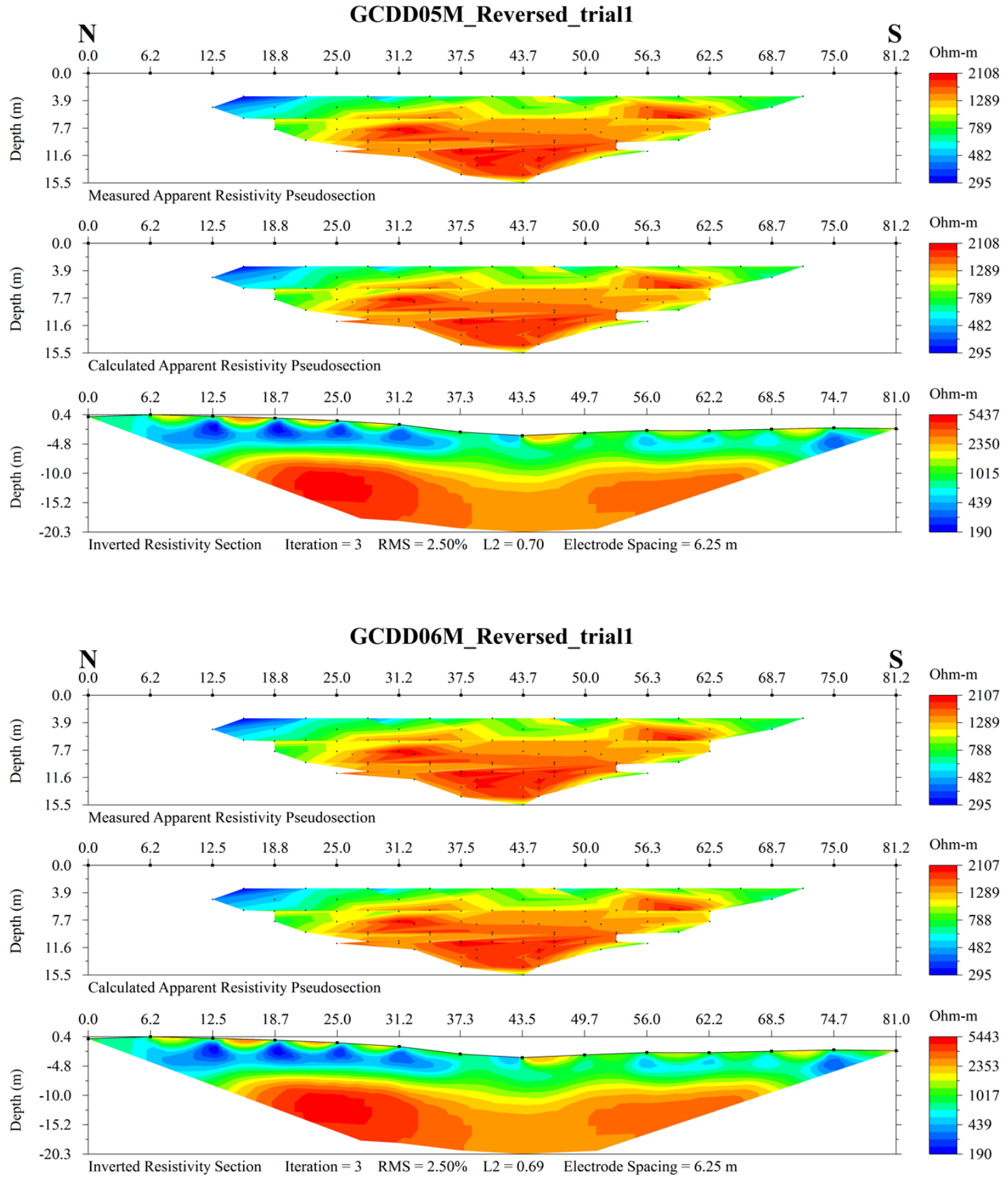

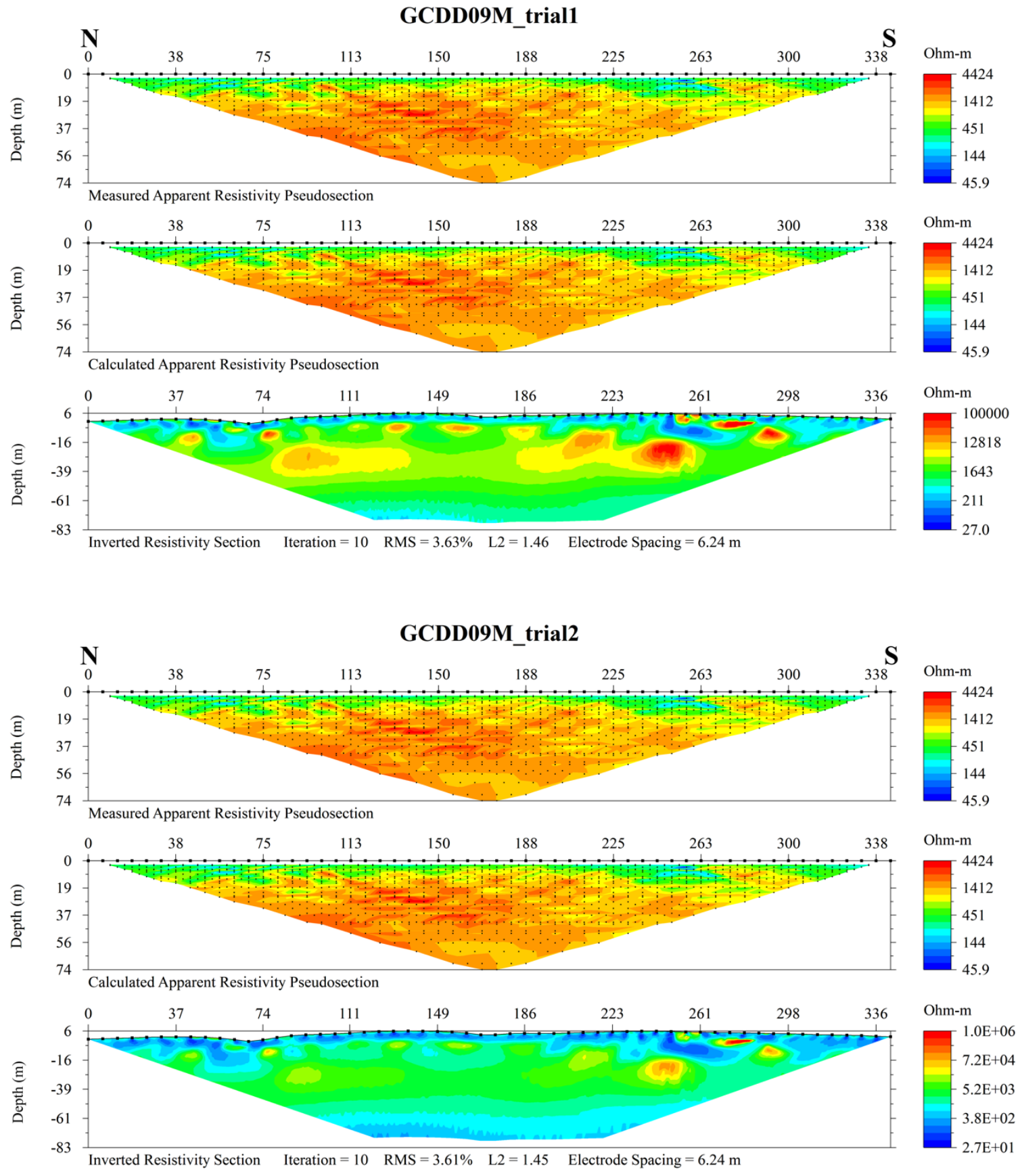

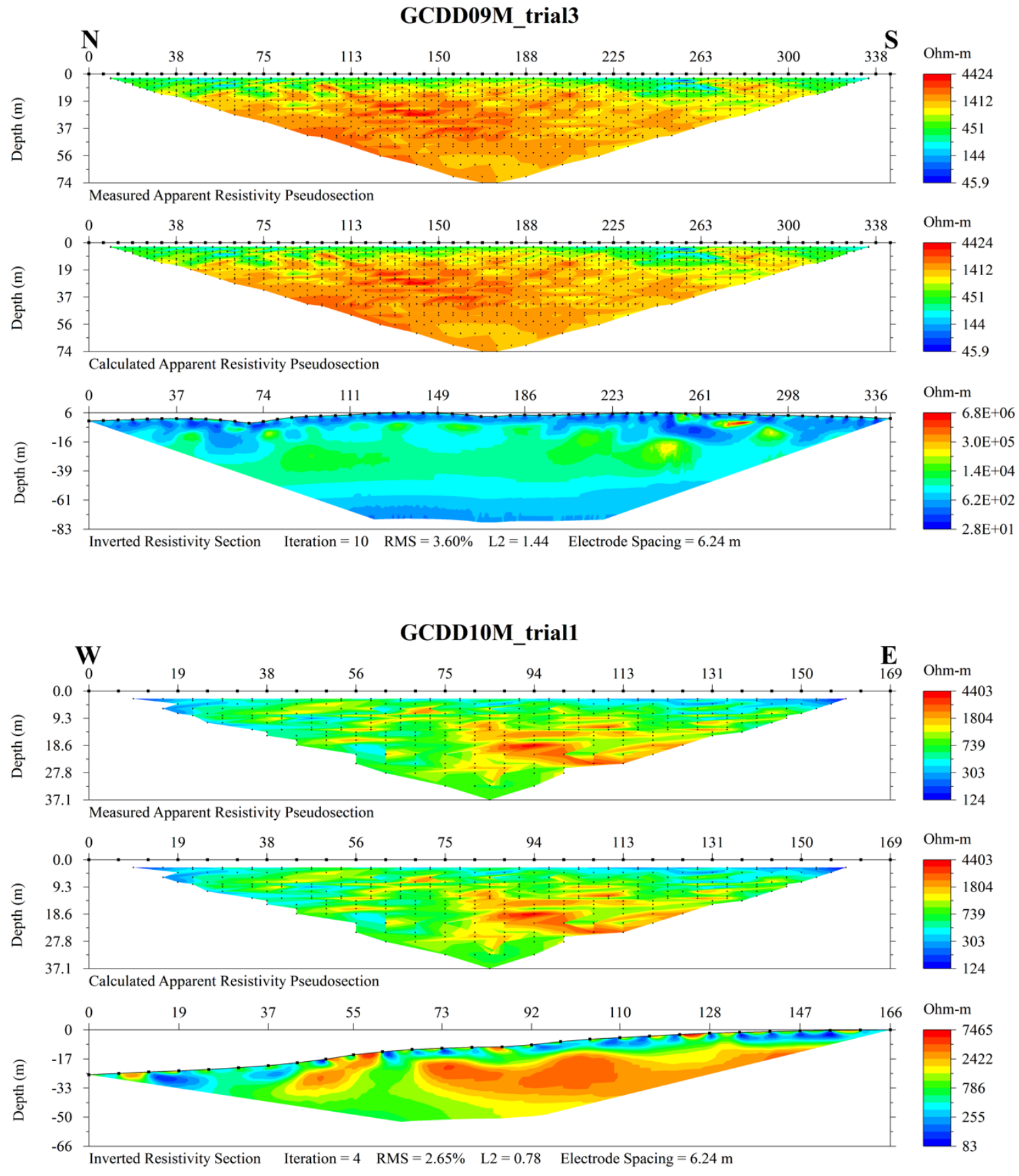


\section{Bibliography}

Advanced Geosystems, Inc., 2007, EarthImager 2D Resistivity and IP Inversion

Software, version 2.4.0, Advanced Geosciences, Inc., Austin, Texas, http://www.agiusa.com/.

Allmendinger, R. W., Cardozo, N. C., and Fisher, D., 2013, Structural geology algorithms: vectors \& tensors: Cambridge, England, Cambridge University Press, p. 289.

Cardozo, N., and Allmendinger, R. W., 2013, Spherical projections with OSXStereonet: Computers \& Geosciences, v. 51, no. 0, p. 193 - 205, doi: 10.1016/j.cageo.2012.07.021.

Chalikakis, K., Plagnes, V., Guerin, R., and Valois, R., Bosch F.P., 2011, Contribution of geophysical methods to karst-system exploration: and overview: Hydrogeology Journal, v. 19, p. 1169-1180, doi 10.1007/s10040-011-0746-x.

Doctor, D.H., Orndorff, W., Maynard, J., Heller, M.J., and Casile, G.C., 2014, Karst geomorphology and hydrology of the Shenandoah Valley near Harrisonburg, Virginia, in Bailey, C.M., and Coiner, L.V., eds., Elevating Geoscience in the Southeastern United States: New Ideas about Old Terranes—Field Guides for the GSA Southeastern Section Meeting, Blacksburg, Virginia, 2014: Geological Society of America Field Guide 35, p. 161-213, doi:10.1130/2014.0035(06).

Doolittle, J. A., and Collins, M. E., 1998, A comparison of EM induction and GPR methods in areas of karst: Geoderma, v. 85, p.83-102.

Edney, C., 2016, Sinkhole opens in Harrisonburg parking lot: WHSV 3, 24 March. 
Esri, Inc., 2013, ArcGIS, version 10.4: Esri, Inc., Redlands California, http://www.esri.com.

Faill, R.T., 1998. A Geologic History of the North-Central Appalachians, Part 3. e Alleghany Orogeny: American Journal of Science, v. 298, p. 131-179.

Gathright, T.M., II, Henika, W.S., and Sullivan, III, 1978, Geology of the Grottoes quadrangle, Virginia: Virginia Division of Mineral Resources Publication 10, 1:24,000 map with text.

Gibson, P.J., Lyle, P., and George, D.M., 2004, Application of resistivity and magnetometry geophysical techniques for near-surface investigations in karstic terranes in Ireland: Journal of Cave and Karst Studies, v. 66, p. 35-38.

Halliday, W.R., 1968, Two centuries of history at the grottoes of the Shenandoah: Grand Caverns and its neighbors: The Journal Spelean History, v.1, p. 1-25. Heller, M.J., Whitmeyer, S.J., Holland, C., Arnette, D., Carter, M.W., and Coiner, L.V., 2007. Southeast-directed backthrusting and crustal thickening in the Massanutten synclinorium, Rockingham and Page counties. Virginia: GSA Abstracts with Programs, v. 39, no. 2, p. 13.

Hutchins, B., Fong, D.W., and Carlini, D.B., 2010, Genetic Population structure of the Madison Cave isopod, Antrolana lira (Cymothoida: Cirolanidae) in the Shenandoah Valley of the eastern United States: Journal of Crustacean Biology, v. 30, no. 2, p. 312-322, doi:10.1651/09-3151.1.

Ismail, I., and Anderson, N., 2012, 2-D and 3-D resistivity imaging of karst sites in Missouri, USA: Environmental \& Engineering Geoscience, v. 18, p. 281-293. 
Kastning, E.H., III, 1995, Evolution of a karstic groundwater system, Cave Hill, Augusta County, Virginia: A multi-disciplinary study, in Beck, B.F., ed., Karst GeoHazards: Rotterdam, Balkema, p. 141-148.

Neuendorf, K.K.E., Mehl, J.P., Jr., and Jackson, J.A., 2011, Glossary of Geology, ed. 5, revised, American Geosciences Institute, p.209.

Leica-Geosystems employees, DATE, Leica Zeno 20, St. Gallen, Switzerland, http://www.leica-geosystems.us/en/index.htm.

Margiotta, S., Negri S., Parise M., and Valloni R., 2012, Mapping the susceptibility to sinkholes in coastal areas, based on stratigraphy, geomorphology and geophysics: Nat Hazards, v. 62, p. 657-676, doi: 10.1007/s11069-012-0100-1.

Marine Geoscience Data System, 2013, GeoMapApp, version 3.6.0, Marine Geoscience Data System, Lamont-Doherty Earth Observatory, Columbia University, Pallisades, New York, http://www.geomapapp.org/.

Nobes, D.C., 1996, Troubled waters: environmental applications of electrical and electromagnetic methods: Surveys in Geophysics, v. 17, p. 393-454.

Nouioua, I., Rouabhia, A., Fehdi Ch., Boukelloul, M.L., Gadri, L., Chabou, D., and Mouici, R., 2012, The application of GPR and electrical resistivity tomography as useful tools in detection of sinkholes in the Cheria Basin (northeast of Algeria): Environ Earth Sci, v. 68, p. 1661-1672, doi: 10.1007/s12665-012-1859-9.

Park, G., Park, S., Yi, M.J., Rim, H., Cho, S.J., and Kim, J.H., 2009, Geostatistical integration using 2-D electrical resistivity and 3-D gravity methods for eetecting 
cavities in a karst area, Environ Earth Sci, v. 60, p. 965-974, doi:

10.1007/s12665-009-0232-0.

Read, J.F., and Repetski, J.E., 2012, Cambrian -lower Middle Ordovician passive carbonate margin, southern Appalachians, in Derby, J.R., Fritz, R.D., Longacre, S.A., Morgan, W.A., and Sternbach, C.A., eds., The great American carbonate bank: The geology and economic resources of the Cambrian-Ordovician Sauk megasequence of Laurentia: AAPG Memoir 98, p. 357-382, doi:10.1306/13331499M980271.

Rader E.K., and Gathright, T.M.II, 2001, Geologic map or the Augusta, Page, and Rockingham Counties portion of the Charlottesville 30 x 60 minute quadrangle: Virginia Division of Mineral Resources Publication 159.

Ryan, W.B.F., S.M. Carbotte, J.O. Coplan, S. O'Hara, A. Melkonian, R. Arko, R.A. Weissel, V. Ferrini, A. Goodwillie, F. Nitsche, J. Bonczkowski, and R. Zemsky, 2009, Global multi-resolution topography synthesis, Geochem. Geophys.

Geosyst., 10, Q03014, doi:10.1029/2008GC002332.

USGS, 2016, unpublished LiDAR [image/data], U.S. Geological Survey. Virginia Department of Emergency Management and Virginia Tech Center for Geospatial Information Technology, 2013, Commonwealth of Virginia Hazard Mitigation Plan, Ch. 3, Hazard Identification and Risk Assessment, Sec. 3.14, Land Subsidence (Karst): http://www.vaemergency.gov/emergency-managementcommunity/recovery-and-resilience/commonwealth-of-virginia-hazardmitigation-plan/ (accessed April 2017)). 
Weber, L. J., J. F. Sarg, and F. M. Wright, 1995, Sequence stratigraphy and reservoir delineation of the Middle Pennsylvanian (Desmoinesian), Paradox Basin and Aneth field, southwestern U.S.A., in J. F. Read, C. Kerans, L. J. Weber, J. F. Sarg, and F. M. Wright, eds., Milankovitch sea-level changes, cycles, and reservoirs on carbonate platforms in greenhouse and ice-house worlds: SEPM Short Course No. 35, Part 3, p. 1-81.

Whitmeyer, S.J., Fichter, L.S., Diecchio, R., Heller, M.J., Eaton, L.S., Cross, A., Coiner, L., Biggs, T.H., Patterson, C.R., 2012, Geology of Page Valley: Stratigraphy, structure and landscape evolution, $42^{\text {nd }}$ Annual Virginia Geological Field Conference.

Williams, P.W., 1983, The role of the subcutaneous zone in karst hydrology, Journal of Hydrology, v.61, p.45-67.

Zinn, B., 2015, Sinkhole on I-81 in Greenville: News Leader, 28 September. 